\title{
Infinite Passion \\ An Essay on Charity and the Self
}

\author{
James Anthony Brown \\ Great Falls, Virginia
}

B. A., University of Virginia, 2010

\begin{abstract}
A Thesis presented to the Graduate Faculty
of the University of Virginia in Candidacy for the Degree of

Master of Arts
\end{abstract}

Department of Religious Studies

August 2013 
For it is the God who said, "Let light shine out of darkness," who has shone in our hearts to give the light of the knowledge of the glory of God in the face of Jesus Christ.

- II Corinthians 4:6

We played the flute for you, and you did not dance... Wisdom is vindicated by her deeds.

- Matthew 11:17-19 


\section{Table of Contents}

$\S 1$ Introduction: Is love all I am?

$\S 2:$ :E $\rho \omega \varsigma$ and the figure of the philosopher in Plato's Symposium

$\S 3:$ Regulating desire: morality and theoretical praxis

§4: Husserl: intentionality and the alter ego

$\S 5:$ Un-stilling the stream

§6: Heidegger: care and ontological dénouement

§7: Gigantomachy for/of Being, or self-love

§8: Love of Being: an impossibility for thought, or self-alienation

§9: Levinas: metaphysical desire and the Other

§10: Marion: the transparent gift of haecceitas, or love opening onto the Other

$\S 11:$ The leap of faith, or the transvaluation in love

$\S 12:$ Inter-missio: erotic transcendence or erotic immanence?

§13: Henry: phenomenality and essential truth

$\S 14:$ Leib and love

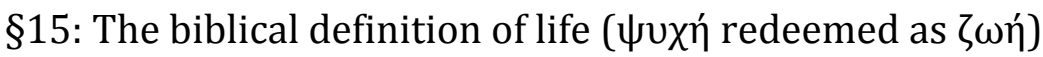

§16: Theo-logy, or the experience of God?

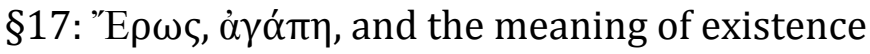

§18: Infinite Passion

§19: Conclusion: Love as a way of life 


\section{§1: Introduction: Is love all I am?}

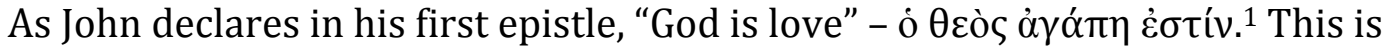
what the Christian faith considers as true. And yet its meaning is far from certain. What is love? From what region of being does it announce itself? What are love's properties? What is its peculiar logic? Furthermore, why might identity obtain - as signified by the copular verb - between God and love? Is the copulative coordinate to being - the characteristics of which, albeit in strict identity to God, would make possible the synthesis of divine and agapic properties within God's very esse? Or does this familiar yet mysterious expression entail a radically non-ontological meaning? That is, does it announce itself from beyond being, or without being? More to the point then, what do we mean by God in the first place? Finally, how does this truth manifest itself? And, what is its philosophical status? Which, of course, demands that we inquire concerning philosophy's task and legitimate scope.

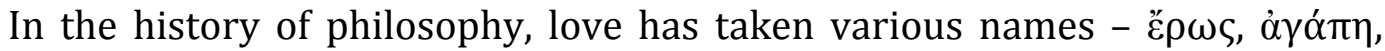
$\varphi \iota \lambda i ́ \alpha$, amor, caritas, dilectio, affection, desire and care, to name a few. This multiplicity is not simply nominal. Love's semantic range seems to reflect its legitimate placement within all of the traditional branches of philosophy epistemology, ontology and ethics. To some degree, love includes all of the above names within itself because it is essentially multivalent in meaning. That is to say, love seems to simultaneously harbor within itself ethical, ontological and epistemological resonances; hence, its prized status. What's more, love seems to be related to the very definition of the self. One needs only to peruse popular culture in order to discover inchoate references to the vital importance of love. We are told that love - happy or not - is strangely more necessary than the air one breathes. It is suggested that healthy love is more than a simple condition of human flourishing. To the contrary: in love, the very notion of the self is determined in such a way that the self is mysteriously dependent upon - if not paradoxically identical to - one's loves. Thus, how could one know thyself ( $\gamma v \tilde{\omega} \theta \iota$ $\sigma \varepsilon \alpha u \tau o ́ v)$ without first knowing a little bit about love? Given this situation, love has sparked fierce debate concerning its philosophical status - not to mention its theological meaning. However, it is beyond doubt that, whatever one's position, love is uniquely important amongst human phenomena.

Amongst those recent philosophers who speak in a phenomenological idiom, love has received a flurry of attention. Michel Henry (1922-2002), a French philosopher and novelist, was particularly interested in Christianity beginning with the publication of his first major work, The Essence of Manifestation. From the start, Henry was a staunch critic of traditional phenomenology, which he argued was codified solely in terms appropriate to the perception of mundane objects. For him, this "ontological monism," wherein all of reality is manifested outside of itself, effectively kills the invisible life that precedes the world. The "exteriority" of worldly disclosure obscures the unique manifestation of the self to itself. Contrastingly, Henry argues for a "material phenomenology" that is based upon an autarkic system of reciprocal phenomenological interiority between life and its $\lambda$ óyos. And, as he

${ }^{1}$ I John 4:16. All English quotations from the Bible are taken from the New Revised Standard Version. 
argued in his first overtly theological work I am the Truth, Christianity's notion of God's self-revelation is essentially indistinguishable from "Life's Archi-revelation." As for love, Henry tells us that "love is nothing other than the self-revelation of God understood in its pathêtik phenomenological essence, specifically, the selfenjoyment of absolute Life." ${ }^{2}$ Love therefore enjoys a certain epistemic significance: it is unique in its ability to manifest ultimate truths.

Emmanuel Levinas (1906-1995), a Lithuanian Jew who emigrated to France as a young student, famously criticized traditional phenomenology in the name of

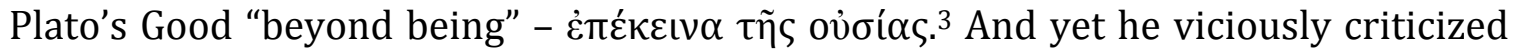
the characteristically Platonic notion of है $\rho \omega \varsigma$ (love). While Henry endorsed a nonintentional conception of love, Levinas rejected है $\rho \omega \varsigma$ for an intentionality that is infinitely directed towards another. "E $\rho \omega \varsigma$, in his view, is generally and characteristically framed in terms of need, possession and self-completion. This occludes the genuine other. "Metaphysical desire," on the other hand, accomplishes one's "relation" with another to the extent that it is imbued with infinite responsibility. At best, ontology and epistemology are relegated to subordinate roles within philosophy; or, at worst, they are considered downright immoral. Thus, when cast in a decisively ethical framework, desire becomes the decisive metaphysical characteristic of human reality.

Strangely enough, while Levinas and Henry seem to represent perfectly inverse philosophical positions, they share common concerns. In particular, even though they remained committed to phenomenological analysis, they reformed the philosophies espoused by Edmund Husserl (1859-1938) and Martin Heidegger (1889-1976) for whom the world is considered the ultimate horizon of manifestation. According to Levinas and Henry, the truth of the world is incapable of capturing ultimate realities. And, in this, they seem to be at one with Christianity. "The world and the desire for it are passing away, but those who do the will of God live forever." 4

And then there is Jean-Luc Marion (b. 1946) who has famously argued for the (phenomenological) primacy of the ego amans over Descartes' ego cogitans. ${ }^{5}$ Following Levinas, Marion privileges concrete, social transcendence over worldly modes of being-in-the-world; yet, unlike Levinas, Marion is more confident in the experiential quality of love, even as it transcends intentional consciousness. "Love should, by hypothesis, make me transcend my lived experiences and my consciousness in order to reach pure alterity." ${ }^{\prime} \mathrm{He}$ does not think that love falls prey to the egocentrism of erotic need; by contrast, he determines the phenomenon of love as the reciprocal self-emptying of the "crossed gazes" of the face-to-face

\footnotetext{
2 Michel Henry, I am the Truth: Toward a Philosophy of Christianity, Susan Emanuel trans. (Stanford, California: Stanford University Press, 2003), p. 31.

${ }^{3}$ Cf. Republic 509b.

${ }^{4}$ I John 2:17.

${ }^{5}$ Jean-Luc Marion, The Erotic Phenomenon, Stephen E. Lewis trans. (The University of Chicago Press, 2003), p. 8.

${ }^{6}$ Jean-Luc Marion, Prolegomena to Charity, Stephen E. Lewis trans. (New York: Fordham University Press, 2002), p. 75.
} 
relation. As such, in the $\kappa \alpha \theta^{\prime} \alpha$ vitó experience of love, the self and the other genuinely appear.

In this paper, I will trace various notions of love as they have been developed within the tradition of phenomenology. I will begin with Plato for whom है $\rho \omega \varsigma$ is the unique (phenomenological) site of beauty and goodness. As we progress, I will attend to the fact that, as philosophy becomes characteristically intellectualist, "ह $\rho \omega \varsigma$ finds itself increasingly relegated to an auxiliary role in the manifestation of "truth." I will then present Husserl and Heidegger as paradigmatic proponents of the truth of the world. Next, I will analyze the criticisms that are leveled against them by Levinas, Marion and Henry. Finally, I will explore a putative congruence of these critical positions with the content of biblical revelation. In particular, we will be focusing on how erotic transcendence accomplishes the inner dynamism of the self, projected beyond worldly modes of being, towards ultimate reality.

Let me be clear that, even though I began with a statement about God, this is not a paper on divine ontology; hence, there is little on the doctrine of the Trinity. This paper more resembles theological epistemology. However, we will not assume a neutral perspective from which we might understand how a "subject" might be able to cognitively engage a particular theoretical object, namely, God. By contrast, I presume what Christianity considers as ultimately true, namely, "God is love." And then the paper asks: how must the subject be - as a dative of manifestation - in order to receive that "truth." In other words, how does the statement "God is love" take concrete meaning? Hence, I have assumed a phenomenological attitude in this paper. In particular, I argue that, in order to receive that "truth," the self is not to be structured according to theoretical intentionality (Husserl) nor ought it exist in the

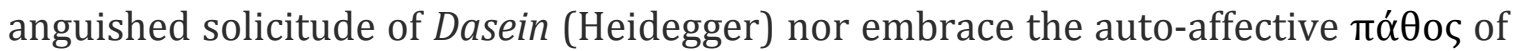
life (Henry). The experience of divine love is hetero-affective and humanity's loving response is structured in infinite passion towards the other (God and neighbor), a superabundant presence irreducible to worldly modes of being or knowledge.

\section{§2: 'E $\rho \omega \varsigma$ and the figure of the philosopher in Plato's Symposium}

For Plato, है $\rho \omega \varsigma$ is significant because it functions to bind everything together - eternal Forms, the immortal gods and mortal souls included. ${ }^{7}$ Love is explored in one of Plato's so-called middle dialogues entitled The Symposium. ${ }^{8}$ The symposium was a ritualized drinking party for the aristocracy in ancient Greece. In Plato's dialogue of the same name, the participants of Agathon's symposium agree to eulogize Love - all the while, tacitly agreeing to a modicum of intellectual seriousness beneath the displays of rhetorical prowess. It must be noted that this eulogy is contextualized by the ancient practice of pederasty. However, certain principles can be extrapolated from the various eulogies, which are applicable to all forms of love. As such, among the eulogists that we will analyze are Phaedrus, Pausanias, Aristophanes and Socrates.

7 Plato, The Symposium, Christopher Gill trans. (London, England: Penguin Books, 1999), 202e.

${ }^{8}$ We must also recognize the Phaedrus and the Lysis. However, I have chosen to investigate the Symposium especially for its erotic definition of the philosopher. 
Agreeing with Phaedrus' ascription of divinity to love, Pausanias discriminates between two forms of love, the heavenly and the common, which correspond to Aphrodite Urania and Aphrodite Pandemos respectively. The common form of love acts without discrimination and for the sake of satisfying one's personal wants - particularly, one's sexual desires. ${ }^{9}$ This type of love is temporary and is not typically concerned with the well being of the beloved. On the other hand, the heavenly form of love is permanent and is based upon the good character of the beloved. ${ }^{10}$ While not bereft of pleasure for the elder lover, this type of love is pursued for the sake of the beloved's moral, political and intellectual education. Heavenly love therefore is a relationship of reciprocity, which is mutually beneficial to the lover and the beloved. Pausanias concludes that Aphrodite Urania is the more praiseworthy god because there is no pursuit more admirable than the pursuit of virtue. ${ }^{11}$

While Pausanias' speech draws out love's ethical implications, Aristophanes' speech draws out love's more metaphysical implications by deploying a brilliant and intriguing myth about the preternatural condition of human nature. According to Aristophanes, human beings were originally joined in pairs so as to form "rounded wholes."12 There were some humans with two male halves; there were some humans with two female halves; and there were some humans with a male half and a female half, which comprised the "androgynous gender." After a thwarted attempt to assault the gods, Zeus decided to split these preternatural humans into their respective halves thereby resulting in humanity's current anthropological configuration. It is within this mythical and metaphysical context that Aristophanes praises love. While fascinating in its wide-ranging implications, we will not concern ourselves with many of the myth's details. Rather, we will focus on the myth's view of love (and desire) as motivated by ontological deficiency and as manifesting humanity's original condition.

Whereas humanity's original condition was characterized by strength and fulfillment, its current condition is characterized by weakness and longing. Love, Aristophanes tells us, "is the name for the desire and pursuit of wholeness." 13 Amongst our various desires, love is our essential one because, while we remain fundamentally incomplete, we seek to reconstruct our very being through the union that is constitutive of erotic activity. Now, erotic desire is uniquely consummated in sexual activity. And yet one's inchoate participation in protological union does not belong by rights to sexual activity alone. Companionship and concern are equally constitutive of erotic fusion. Erotic activity is therefore multidimensional. Nevertheless, we may say that the activity that is definitive of human beings is erotic activity to the extent that it pre-eschatologically participates in the completeness of humanity's protological condition.

\footnotetext{
${ }^{9} 181 \mathrm{~b}$.

$10183 \mathrm{e}$.

11 185b.

12 189e. The complete myth can be found in $189 \mathrm{~d}-191 \mathrm{c}$.

$13192 \mathrm{e}$.
} 
Invoking eschatology here is not misplaced. Let us quote Aristophanes at length so as to understand the extent to which erotic activity is efficacious in fulfilling its own internal dynamic. Aristophanes tells us that

our human race can only achieve happiness if love reaches its conclusion, and each of us finds his loved one and restores his original nature. If this is the ideal, under present circumstances what comes closest to it must be the best: that is to find a loved one who naturally fits your own character. If we want to praise the god who is responsible for this, we would rightly praise Love. In present circumstances, he does the best for us that can be done, leading us towards what is naturally close to us. He also holds out to us the greatest hopes for the future: that if we show reverence towards the gods, he will restore us to our original nature, healing us and so giving us perfect happiness. ${ }^{14}$

Erotic activity alone is capable of attaining ontological completion, albeit to a limited degree. Why is it limited in potency? In the first place, the union of erotic activity is patently temporary. Secondly, it is rare that humans find the precise individual with whom they were originally fused. For these reasons, erotic activity requires external intervention in order to complete its internal teleology. Aristophanes therefore places genuine fulfillment in a religious and eschatological framework: as long as humans reverence the gods, then they will achieve permanent union in the future.

Interestingly enough, Aristophanes' remarks concerning love are not simply metaphysically speculative, nor are they merely mythological. To the contrary: Aristophanes places his remarks in a vaguely phenomenological idiom. ${ }^{15}$ In the first place, he mentions the joy that true lovers feel. ${ }^{16}$ Erotic companionship is enjoyable. What is the significance of enjoyment? From the feeling of joy, one is able to grasp the metaphysical situation of है $\rho \omega \varsigma$. To be specific, it seems that the satisfactory character of joy is revelatory of one's (partial) fulfillment within the context of the erotic union. But, joy is always - if not necessarily - tempered by desire. To see why, let us distinguish joy from happiness. Happiness, which is enduring satisfaction, is attained only at love's permanent consummation. Joy, on the other hand, is only the foretaste of one's eschatological condition wherein human beings will be restored to their original natures. Love's desiring aspect tempers its enjoyable aspect. While internally motivated towards interpersonal union, desire is ultimately restless. Desire, it seems, is revelatory of humanity's current and unavoidable metaphysical deficiency. Nevertheless, in the face of one's beloved, Aristophanes tells us that the lover is "overwhelmed, to an amazing extent, with affection, concern and love ...

\footnotetext{
14 193c-d.

15 I recognize that Aristophanes is not self-consciously speaking in a phenomenological idiom; however, he thinks that certain experiences are indeed revelatory of his metaphysical schema.

16 192c.
} 
[and] like an oracle, he half-grasps what he wants and obscurely hints at."17 Love is both desirous and enjoyable, the aspects of which are revelatory of ultimate realities - if perhaps only obscurely.

As simultaneously desirous and enjoyable, love is revelatory of the "order of things." To be specific, the love between two human beings (i.e. है $\rho \omega \varsigma$ ) dynamically manifests the original wholeness and current incompleteness of human nature. To be sure, the meaning of the seemingly necessary relationship - within $\varepsilon^{\circ} \rho \omega \varsigma$ itself between the satisfactory character of joy and the longing character of desire is scarcely clarified by Aristophanes. As Levinas will point out, the simultaneity of

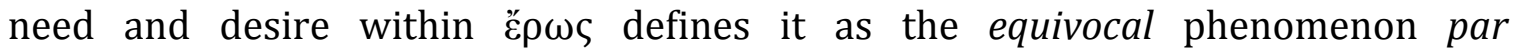
excellence. ${ }^{18}$ What's more, if we are to turn a critical eye towards Aristophanes speech, it is unclear that love's proper object is another human being. Why is another human being more fulfilling than objects, which can also be said to be lovable? Perhaps, one might distinguish the joy of companionship from the joy of possessing or using objects. And, is love directed towards an individual qua individual? This final question concerning individuality seems to place the modern context at its greatest distance from the ancient context. But, our survey of Plato's Symposium has scarcely been a waste. While we must bracket the metaphysical and mythological context of the aforementioned speeches, we may nonetheless treat Aristophanes and Socrates as guiding threads in our further consideration of love as revelatory of the "order of things."

Socrates demythologizes his interlocutors and clarifies love's relational character. While admiring the fact that Agathon eulogizes love's nature as opposed to love's effects, Socrates dialectically exposes the inconsistency of Agathon's view that love is a great and beautiful god. Agathon told his fellow winebibbers that love is "supreme in beauty and excellence and is responsible for similar qualities in others." ${ }^{19}$ That is to say, all good gifts (health, peace, luxury, etc.) come to the gods and human beings on account of love's harmonious organization of the cosmos, which is possible because love itself is the most virtuous and the most beautiful of the gods. Socrates responds: "Is it not Love's nature to be love of something?" Love qua desire is directed at that which is not possessed - at that which is presently needed but remains nonetheless absent. If this is true, then love cannot itself subsist in beauty and excellence if it is determinately lacking in those things. Having contradicted Agathon's view, Socrates claims that $\varepsilon^{\circ} \rho \varsigma$ is a sort-of intermediary

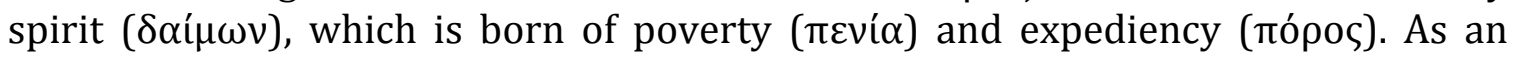

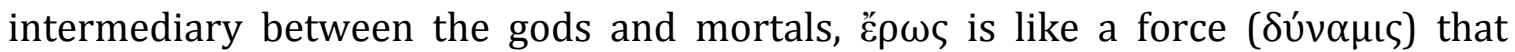

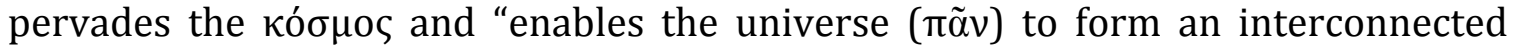
whole." 20 For Socrates, love desires beauty itself - perfect and eternal - and, having discovered true beauty, $\check{\varepsilon} \rho \omega \varsigma$ gives birth to true virtue ( $\left.\dot{\alpha} \rho \varepsilon \tau^{\prime}\right) .{ }^{21}$ Thus, even though

\footnotetext{
17 192c-d, my emphasis.

${ }^{18}$ Emmanuel Levinas, Totality and Infinity: an Essay on Exteriority, Alphonso Lingis trans. (Pittsburgh, Pennsylvania: Duquesne University Press, 1969), p. 255.

19 197c.

$20202 \mathrm{e}-203 \mathrm{a}$.

$21212 \mathrm{a}$.
} 


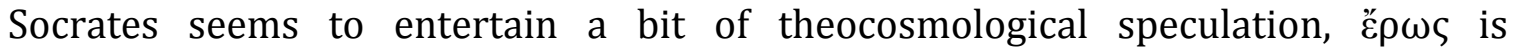
unambiguously depicted as the mythic personification of the originary force that subtends the multidimensional array of human drives - all of which culminate in the vision of the ultimate source of all beauty. That is to say, in pursuit of happiness and flourishing, है $\rho \omega \varsigma$ constitutes humanity's essential relation to the divine principles of wisdom, goodness and beauty.

"E $\rho \omega \varsigma$ seems to be coextensive with philosophy: "love must necessarily be a

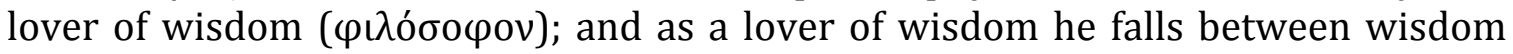
and ignorance." 22 Yet the erotic model of the philosophical life presents a crossroads: either है $\rho \omega \varsigma$ is inevitably discontinued in the event of attaining its object, or it persists and even augments itself when face-to-face with wisdom, beauty and goodness. On the former interpretation, philosophy would figure as the pursuit of theoretical knowledge (episteme), which is utterly transcendent to ignorance and permanently possessive of wisdom. That is to say, coordinate to (objective) being, $\theta \varepsilon \omega \rho i \alpha$ would overcome the inherent deficiency of (epistemic) desire - even as it

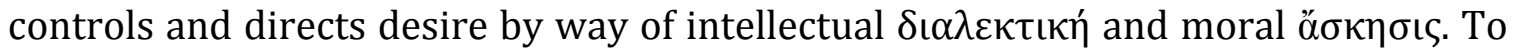
be sure, this represents a dominant strand in the history of thought, and we will investigate it later. However, the situation seems to be more complex in the Socratic-Platonic tradition for which the philosophical life seems to consist in a

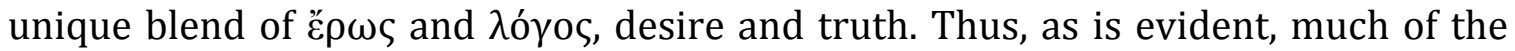
discussion concerning love hinges on the status of desire. Is it negatively characterized as need or is it positively characterized as passion (for something that remains transcendent)? Along with Nietzsche, we suspect that Socrates - who is the historical personification of the philosopher and the only eulogizer to remain simultaneously drunk and awake - is not a theorist but the eroticist par excellence. ${ }^{23}$

Pierre Hadot has meticulously drawn attention to the erotic contours of the Socratic-Platonic determination of the philosopher. According to the opposition of contrariety, the philosopher is neither wise nor ignorant. ${ }^{24}$ This contrariety is established from within the category of the "non-sage" - a category that is in contradictory opposition to the sage and, by extension, the gods. On the one hand, the gods do not desire wisdom because they already possess it; on the other hand, the ignorant do not desire wisdom because, "despite not being good or intelligent, he regards himself as satisfactory." 25 Thus, the wise and the ignorant surprisingly share a common trait, namely, they lack desire (for wisdom). Contrastingly, desire is definitive of the philosophical life. It must be emphasized that, as a lover of wisdom, the philosopher is not represented by the figure of the sage who is possessive of wisdom. Whereas the sage represents the perfection that is appropriate to divine beings, the non-sage is a sub-lunar being that is fundamentally subject to the vicissitudes of time and the limitations of imperfection. While attracted to wisdom,

\footnotetext{
22 204b.

23 Friedrich Nietzsche, The Birth of Tragedy, out of the Spirit of Music, Shaun Whiteside trans. (London, England: Penguin Books, 2003), section 13.

24 Pierre Hadot, What is Ancient Philosophy?, Michael Chase trans. (Cambridge, Massachusetts: Harvard University Press, 2002), p. 46.
}

25 204a. 
beauty and goodness, the philosopher is intimately aware of his or her inexorable inability to attain those divine qualities. Knowing that he or she knows nothing, the philosopher falls between ignorance and wisdom. And yet love's patrimony includes expediency as well as poverty. Thus, in the manner of an internally directed desire, ๕ $\rho \omega \varsigma$ enables the philosopher to asymptotically advance towards wisdom.

"According to the Symposium, then, philosophy is not wisdom, but a way of life and discourse determined by the idea of wisdom."26 Specifically, the philosophical way of life is neither supreme indifference vis-à-vis the world nor is it a complete embrace of worldly modes of being. To the contrary: without departing from the strictures of world yet by way of the essentially erotic vision of transcendent beauty, the philosopher can approach true virtue and happiness in the midst of worldly abundance and privation. While Socrates' interlocutors canvassed impressive theories, they ultimately "congratulated human beings on the good things that come to them from the god [ย́ $\rho \omega \varsigma] . " 27$ Smashing these self-idolatrous conceptions of है $\rho \omega \varsigma$, Socrates exposes intellectual and moral deficiencies thereby creating the space for self-transcendence from out of the complacency of feigned perfection (sophistry). That is, ineluctably drawn towards transcendent wisdom, Socrates vigilantly questions the self-sufficiency of this-worldly knowledge; thus, the Socratic mode of life, in the form of passionate inquiry and erotic ecstasy, corresponds to the transcendent intelligibility of the world. "Here philosophy appears as an experience of love." 28

\section{§3: Regulating desire: morality and theoretical praxis}

In contemporary discussions, love is not considered nearly as ennobling as Plato's है $\rho \omega s$. It is said that love withdraws from the conceptual rigor that is appropriate to science or philosophy. At best, love is a confused and obscure perception; at worst, it is completely ignorant of the other and it merely reflects the ego's own subjectivity. This situation is understandably unpalatable. According to modern philosophy, love does not possess the power of the cognitive faculty, which discloses the nature of the objective world; nor does it possess the dignity of the beneficent will, which conforms to the universality and reciprocity of the moral law. Thus, erotic love must be regulated by a more universal love, a love of truth - moral and intellectual. Let us explore erotic love's degradation.

In The Passions of the Soul, Article LXXIX, Descartes defines love as "an emotion of the soul caused by the movement of the spirits which incites it to join itself willingly to objects which appear to it to be agreeable."29 As a passion, all emotions originate from outside of the soul but are nonetheless attributable to the soul, which is to say that the passions are the soul's affective responses to the outside world. Love therefore engages a transcendent entity, which is perceived to be able to complete the ego's desire to be a unified whole. Descartes elaborates: love is "the

\footnotetext{
${ }^{26}$ Hadot, What is Ancient Philosophy?, op. cit., p. 45-6.

27 194e.

${ }^{28}$ Hadot, What is Ancient Philosophy?, op. cit., p. 48-49.

${ }^{29}$ René Descartes, The Passions of the Soul, Elizabeth S. Haldane and G. R. T. Ross trans. (Cambridge University Press, 1967).
} 
consent by which we consider ourselves from this time forward as united with what we love, so that we imagine a whole of which we conceive ourselves as only constituting one part, while the thing loved constitutes another part." 30 It seems that, by characterizing oneself as part of a whole, love humbly submits the self to another, as in a hierarchy. Yet the "whole" is subjectively determined: the lover's "consent to union" merely reflects the ego's personal preferences and arbitrary sentiments. Here's why. Because love is characterized as a passion, the other has a tendency to appear as a "confused and obscure perception," to use Descartes' words. ${ }^{31}$ Even though the passions establish affective access to the outside world, they do not achieve the clarity and distinctness of cognition. As such, unable to penetrate the opacity of the transcendent world, the passions remain organized only by the subjectivity that they provoke. Love is therefore ignorant of that which it loves, unable to appear in its own right. Marion describes the situation: the beloved (whether it is a mere object, another person, being itself, or even God) "merely provides the occasion for a union of will that is irrational (by virtue of passion) and solipsistic (by virtue of the primacy of subjectivity)." 32 The other is therefore loved only to the extent that it fulfills the private desires of the loving subject.

Modern philosophy has sought to temper this negative aspect of love by imbuing it with universality. Universal love has two variants: love based upon beneficence and love based upon theoretical praxis. Let us examine each.

(1) Love must conform to the moral law that is inscribed in the sovereign good of humanity. It is no surprise that love is sometimes complicit with immorality. Because love expresses subjective preferences, it acts for the sake of satisfying one's personal wants, often to the detriment of another. Thus, following Pausanias, beneficent love (Aphrodite Urania) is recognized as a necessary buffer to the potential injustices of private love (Aphrodite Pandemos). That is to say, love must be properly ordered by the universal moral law in order to contribute to genuine human flourishing - independently of the subjective preferences of particular individuals. Universal, beneficent love can and must order the will, that which belongs most properly to the individual subject. Distinguishing commanded love from sentimental love, Kant argued that "love as an inclination cannot be commanded; but beneficence from duty, when no inclination impels us and even when a natural and unconquerable aversion opposes such beneficence, is practical, and not pathological, love. Such love resides in the will and not in the propensities of feeling, in principles of action and not in tender sympathy; and only this practical love can be commanded." 33 Individual, passionate love ought to be regulated by the disinterested, rational love for humanity, which first understands the universality and reciprocity of the moral law as it governs human action.

(2) In the modern age, theoretical praxis-scientific pursuit-has become the definitive activity of human beings. While love is considered a type of

30 Descartes, The Passions of the Soul, op. cit., article LXXX, my emphasis.

31 Descartes, The Passions of the Soul, op. cit., article XXVIII.

32 Marion, Prolegomena to Charity, op. cit., p. 157.

33 Immanuel Kant, Grounding for the Metaphysics of Morals, James W. Ellington trans. (Indianapolis, Indiana: Hackett Publishing Company, 1993), p. 12. 
knowledge, it is a confused and obscure perception of the other (at best), which tends to slide into solipsism (at worst). If it is not to remain the trivial expression of arbitrary sentiments, love is thought to achieve true knowledge only by way of theoretical praxis - that is, as intellectual love. For the intellectualist, knowledge is a type of comprehensive vision, which assembles and synthesizes all that can be perceived into a system of intelligible relations. True knowledge is distinguished from mere belief by way of the first principles of the understanding. Thus, sensations become knowledge only to the extent that they are modeled according to the understanding. Vision, seen as the privileged sense, works to manifest objects by bringing them into the light of being-the comprehensive whole. Hence, Aristotle's Metaphysics, which purports to study "first principles," is an investigation into being qua being. The modern project is homologous. Even though Kant shifts the domain of philosophy from being to the transcendental ego, Kant culminates this tradition. Aesthesis, by way of the categories and under the unity of apperception, transcendentally works to yield knowledge. As such, the ego is always already hardwired according to the universal categories of reason and understanding Vernunft and Verstand - to which private judgments must conform. That is to say, the neutral, anonymous perspective of science transcends the (epistemological) limitations of private belief - tainted as they are by the affections (which are opaque) and volitions (which are capricious) - by submitting intuition to the universal structures of the judgment-forming power of the cognitive faculty. Hence, science (as an all-inclusive synthesis of knowledge) is considered the noblest achievement of human life - a tradition of thought that spans back to Aristotle for whom contemplation is the supreme good, which hierarchically orders the other human goods. ${ }^{34}$ Thus, if not merely a problem for moral philosophy, desire must be positively transmuted into the more dignified love of and passion for truth.

But love does not seem to be stuck in this unfortunate dichotomy, namely, capricious love regulated by love of truth. Love seems to possess a legitimate universal structure that is irreducible to arbitrary sentimentalism, and it seems to exceed the dictates of the moral law as well as the rules of judgment-formation. In short, the object of love is neither an object of scientific knowledge nor simply an object of private sentiment. Love, it is thought, constitutes unique "epistemic" access to the other - which, in its very alterity, is otherwise unknowable. Admittedly, this knowledge is inherently private. It is a well-known frustration for lovers to explain their love to a neutral third party; only from within the love relation do the lovers "know" each other. Yet the knowledge that is given through love is nonetheless considered genuine for it enables the other to appear in its own right, even if in a private manner. Thus, love of the other is contrasted with loves of truth, which, Marion tells us, "attain, in the best of cases, the rank of understanding of the abstract universal, and the force of regulatory obligations." ${ }^{35}$ Love of truth enables the other to appear only as an instance of generalized "humanity," albeit a dignified individual

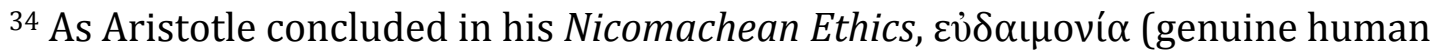
flourishing) consists in contemplative activity - vision of the highest structures of reality. 35 Marion, Prolegomena to Charity, op. cit., p. 160. 
who deserves respect and justice. Nevertheless, intellectualism transmogrifies love into the rational comprehension of an abstract universal to the occlusion of the unique other. Contrastingly, love is purported to be a genuine experience of the other - the individual par excellence - through a union of affect and will. Note: we must keep the will and the affections in mind as we proceed, even if they are not thematized initially, since they are essential components of the phenomenon of love. Yet the will and the affections do not derogate from the legitimate "transcendent" character of love. For love is neither irrational nor merely affective but furnishes knowledge of the other, an utterly unique but genuine experience of alterity that exceeds ordinary knowledge.

In order to overcome this impasse (in the pursuit of knowledge of the other), let us go beyond the moral law - for the other remains unknown to moral philosophy even if afforded justice and respect - and let us go beyond the neutrality of intellectualism - for the other remains unknown to the intellect except as an instance of a universal. Going forward, we will focus on the philosophical tradition of phenomenology since it seeks to provide conceptual rigor and universal import to the field of experience. Would not a philosophy of "experience" slide into the same problem, namely, love as an arbitrary sentiment, because "experience" is inherently private? Not necessarily. Phenomenology attempts to analyze the universal, transcendental structures of human experience without prejudicing the meaning of the objects of experience with private interpretations. Without further ado then, let us interrogate the phenomenological structure of love, which, as an experience, establishes the only epistemic relation with the other.

\section{\$4: Husserl: intentionality and the alter ego}

To that end, let us look narrowly at the doctrine of intentionality and then more broadly at its relationship to the problem of knowledge in general. From there, we will investigate Husserl's solution to the particular problem of knowledge of the other for, with this problem, the unique phenomenon of love is to be explicated.

For Husserl, reality is susceptible of being known in virtue of the intentionality of consciousness. The concept of intentionality expresses that which initially seems trite, namely, "consciousness is consciousness of something." 36 Perception is consciousness of that which is perceived; imagination is consciousness of that which is imagined; valuation is consciousness of that which is valued; consciousness is "consciousness of..." The concept of intentionality is not a metaphysical attribute of consciousness, whose essential determinate is the cognitive faculty. That is to say, intentionality does not entail a self-enclosed subject, which, mysteriously transcending itself, cognitively "latches onto" an objective entity thereby accomplishing the relation of "consciousness of..." There is no room here for the subject-object distinction. Rather, intentionality is an existential thesis: it describes the very self-transcending mode of existence of consciousness itself. Consciousness is

${ }^{36}$ Edmund Husserl, Ideas Pertaining to a Pure Phenomenology and to a Phenomenological Philosophy, First Book: General Introduction to a Pure Phenomenology, F. Kersten trans. (The Hague: Martinus Nijhoff Publishers, 1983), section 36. 
consciousness of... Yet, again, this existential thesis seems beholden to the subjectobject distinction. To the contrary: it describes the intrinsic character of mental life itself. Within Erlebnisse, we find not only a multiplicity of sensations but also the bestowal of meaning to that very flow of sensations within consciousness. Intentionality is "essentially the act of bestowing a meaning (the Sinngebung)." ${ }^{37}$ Specifically, Husserl finds that the transcendence of the Sinngebung reflects a retentional-protentional structure deep within consciousness. This structure constitutes a "horizon" - ecstatically radiating beyond the Urimpression - against which objects are manifested. "An existent is comprehended in the measure that thought transcends it, measuring it against the horizon whereupon it is profiled." 38 Knowledge occurs precisely in the relations that are constituted by the horizon. And, because the horizon makes possible the bestowal of meaning, "idealism, the Sinngebung by the subject, concludes all this realism of meaning."39

In order to properly understand the import of the doctrine of intentionality, it is illuminating to discuss it against the backdrop of the peculiarly modern formulation of the problem of knowledge. For the ancients, epistemology determined the criterion by which genuine knowledge is constituted - as distinguished from mere belief. Typically, however, the ancients did not systematically interrogate the possibility of knowledge. Descartes, at the dawn of the modern age, questioned the relation of thinking substance and extended substance thereby radicalizing the epistemological problem. Or, stated in the form of a question, Descartes asked how can the immanent achievements of cognitive life (clara et distincta perceptio, Evidenz) be extended to the transcendent world and thereby acquire objective significance? The problem has since seemed intractable. Husserl treats this as a pseudo-problem generated from the natural, pre-critical attitude - namely, the tendency to apply the spatiotemporal and causal categories of substance to the transcendental sphere of experience. It is an error, on Husserl's view, to ascribe sense to "transcendence" and "immanence" from within the natural attitude. Transcendence does not imply a simple "out there" that stands over and against the "in here" of subjective immanence. To the contrary: as Husserl tells us in

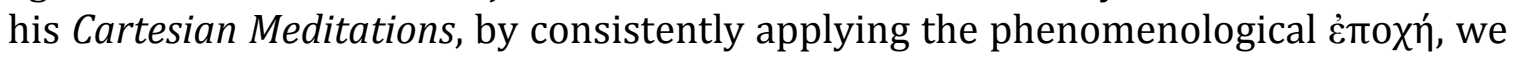
are led to recognize that "transcendency in every form is an immanent existential characteristic, constituted within the ego." 40

The intentional structure of experience (and its Sinngebung) everywhere determines the concrete unity of immanence and transcendence, subject and object, spirit and nature, constituted within transcendental subjectivity. To be sure, there are natural subjects (as psychophysical unities) and there is the natural world (as a transcendent objectivity) - and they are dialectically related according to the

37 Emmanuel Levinas, Discovering Existence with Husserl, Richard A. Cohen and Michael B. Smith trans. (Evanston, Illinois: Northwestern University Press, 1998), p. 59.

${ }^{38}$ Levinas, Totality and Infinity, op. cit., p. 44.

${ }^{39}$ Levinas, Totality and Infinity, op. cit., p. 95.

${ }^{40}$ Edmund Husserl, Cartesian Meditations: an Introduction to Phenomenology, Dorion Cairns trans. (Kluwer Academic Publishers, 1999), p. 83-84, my emphasis. 


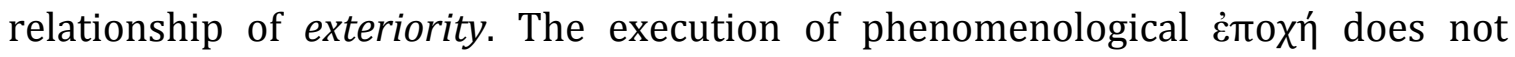
thereby falsify the natural attitude. In fact, the situation is precisely the opposite: natural being derives its legitimate sense from transcendental being, as recovered

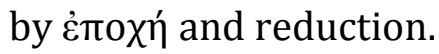

Every imaginable sense, every imaginable being, whether the latter is called immanent or transcendent, falls within the domain of transcendental subjectivity, as the subjectivity that constitutes sense and being. The attempt to conceive the universe of true being as something lying outside the universe of possible consciousness, possible knowledge possible evidence, the two being related to one another merely externally by a rigid law, is nonsensical. They belong together essentially; and, as belonging together essentially, they are also concretely one, one in the only absolute concretion: transcendental subjectivity. If transcendental subjectivity is the universe of possible sense, then an outside is precisely - nonsense. ${ }^{41}$

Thus, Descartes' progeny became entangled in intractable contradictions not only because of the hidden residues of scholastic metaphysics but also because they inconsistently applied the $\dot{\varepsilon} \pi 0 x \eta$. The very possibility of the question of the possibility of transcendent knowledge presupposes the anterior validity of the ego's apperception of transcendent being-that is, the objective world has already entered into the sphere of experience. To question, for example, whether or not my concept of a baseball truly represents an objective baseball presupposes the validity of my apperception of the baseball. Universal doubt should not have cleaved res

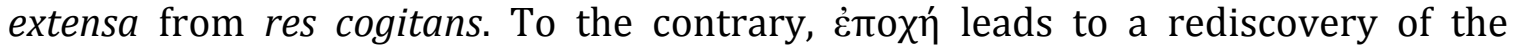
transcendent world as already given to consciousness, as meaningfully there. Thus, if transcendency is always already given to consciousness, then the proper philosophical task is sense-explication, which signifies the "systematic uncovering of the constituting intentionality itself." 42 Reciprocally, intentional method necessarily entails the (phenomenological) unity of idealism and realism. In this sense, Husserl explicitly follows the Delphic Oracle and Augustine for whom truth is discovered through self-examination. ${ }^{43}$

We are in a promising place for two reasons. (1) If one can deploy a rigorous application of intentional method to the phenomenon of love such that it uncovers (that is, gives sense to) a unique domain of being (namely, "the other"), then phenomenology has overcome the impasse in conceptually determining the illusive yet significant phenomenon of love. (2) Let us note a less obvious point, which will only become clear over the course of this essay. We are even closer to restoring love

\footnotetext{
${ }^{41}$ Husserl, Cartesian Meditations, op. cit., p. 84.

${ }^{42}$ Husserl, Cartesian Meditations, op. cit., p. 86.

${ }^{43}$ Husserl concludes his Cartesian Meditations by invoking the Delphic motto, $\gamma v \omega \theta \mathrm{u}$

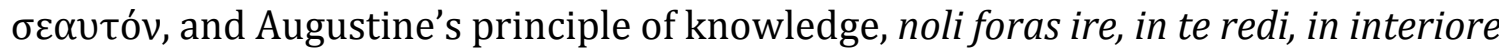
homine habitat veritas.
} 
as the fundamental human experience, the basic drive that subtends all others - as है $\rho \omega \varsigma$ was for the Greeks. Let us go deeper.

As Marion has rightly pointed out, intentionality characterizes the crucial paradox of consciousness: namely, "the 'lived experiences of consciousness' (vécus de conscience, Erlebnissen) do not concern uniquely, nor even first, my consciousness, but objects transcendent and exterior to it, everything in it remaining immanent and so to speak coextensive. The lived experiences that weave the fabric of my consciousness nevertheless aim at an intentional object irreducible to my consciousness." ${ }^{4}$ Not merely self-aware, consciousness is affected by transcendent objects and thereby has an immanent experience of them. The experience of exteriority is made possible by the intentional structure of consciousness. That is to say, intentional consciousness is essentially directed ad extra even as intentionality remains an intrinsic aspect of consciousness itself. Or, stated otherwise, intentionality is the structural basis for the essential polarizing of experience - that is, the establishment of "ownness" (the self-identical ego) and "otherness" (objective nature), included within the very field of experience. This paradoxical structure, so it seems, enables the ego to escape the aporia of selfenclosure - all the while maintaining the irreducible nature of transcendent exteriority. By implication, if intentionality concerns that which is genuinely transcendent, then it seems that alterity accomplishes the ego's very own intentional mode of being. Love is supposed to be none other than the experience of pure alterity, which is precisely the paradox of intentional consciousness. Thus, ought we conclude that love is the preeminent and paradigmatic experience of intentional consciousness? Or, going further, is love therefore coextensive with intentionality? As such, would not an intentional analysis of love thereby complete the aspirations of the phenomenological project (understood as intentionality polarized towards alterity)? Asked otherwise, does not intentionality restore the erotic intelligibility of the world? At a minimum, doesn't it tear us away from the view of love as a mere reflection of the self's sentiments and preferences?

The situation, as we shall see, is not so simple. In order to understand why, we must explore the constitutive differences between subjects and objects - nota bene: constitutive differences as understood from within the transcendental attitude. For that analysis, we now turn to Husserl's fifth Cartesian Meditation, which stands as a potential crack in the phenomenological system - the idea of philosophy as the all-inclusive unity of the sciences, absolutely grounded in transcendental subjectivity. Husserlian phenomenology is profoundly haunted by the specter of "transcendental solipsism." 45 Having completed the sketch of his scientific system in $\S 41$ of the fourth Cartesian Meditation ("genuine phenomenological explication of one's own 'ego cogito' as transcendental idealism"), Husserl wonders at the ability to reach beyond the ego's sphere of experience and the unities of sense contained therein in order to attain transcendent knowledge - an epistemic relation with that which is truly other. Isn't this the very problematic feature of Cartesian thought, which Husserl laid to rest? Or does its recurrence present a perennial problem for

${ }^{44}$ Marion, Prolegomena to Charity, op. cit., p. 72.

${ }^{45}$ Husserl, Cartesian Meditations, op. cit., p. 89. 
transcendental philosophy? Does the very notion of the other represent a scandal to the pretensions of transcendental idealism? Husserl doesn't believe so: phenomenological explication can uncover a genuine sense of the other by way of the concept of the alter ego - intentionally constituted.

Before we look at Husserl's solution, let us highlight both aspects of the double-edged threat of "the other." (1) Husserl is deeply committed to the universal applicability of intentional analysis in virtue of natural being's unqualified dependence on transcendental subjectivity. Everything, so it seems, is constituted in its existence-sense (Seinssinn) by intentional consciousness. "The other" is no different. (2) Yet "the other" does not simply threaten the absoluteness of transcendental subjectivity. For, as Husserl is well aware, the existence-sense of the objective world is intersubjectively dependent. But, how are we to understand the "subjective" dimension of this dependency? When we encounter another, we experience animate organisms - which, as psychophysical unities, are simultaneously objects " $i n$ " the world and subjects "for" the world. As a subject, the other experiences objects as there-for-itself in the same way that I experience objects as there-for-me. Correspondingly, the objective world is not simply therefor-me but also there-for-everyone. Thus, in an essential way, a theory of empathy contributes to our understanding of the constitution of the objective world, in its most rigorous and legitimate sense. Stated negatively, if other egos are noematically inscribed in the existence-sense of the object (as there-for-everyone), then any lack of access to the other threatens our knowledge of the object as well. Here, love is cast into doubt yet again. Can we comprehend an object if we cannot first love each other?

Attempting to discover an intentional sense of the other, Husserl proposes a second reduction in the fifth Cartesian Meditation - a "reduction of transcendental experience to the sphere of ownness." 46 As suggested in this phrasing, this is not an alternative reduction but is a successive reduction that is conducted from within the transcendental attitude. Husserl divides the transcendental field of experience into that which is peculiarly my own and that which is alien to myself. As we shall see, this reduction is necessary because the individual ego experiences the other by a certain apperceptive "mirroring" whereby the other's existence-sense is analogous even if not identical - to the self. Husserl summarizes:

Restricting ourselves to the ultimate transcendental ego and the universe of what is constituted in him, we can say that a division of his whole transcendental field of experience belongs to him immediately, namely the division into the sphere of his ownness - with the coherent stratum consisting in his experience of a world reduced to what is included in his ownness (an experience in which everything "other" is "screened off") - and the sphere of what is "other." Yet every consciousness of what is other, every mode of appearance of it, belongs

46 This is the title of $\$ 44$ of the Cartesian Meditations, which outlines the strategy for pursuing the leading clue encoded in objectivity (namely, "thereness-for-everyone"). My emphasis. 
in the former sphere. Whatever the transcendental ego constitutes in that first stratum, whatever he constitutes as non-other, as his "peculiarly own" - that indeed belongs to him as a component of his own concrete essence ... it is inseparable from his concrete being. Within and by means of this ownness the transcendental ego constitutes, however, the "Objective" world, as a universe of being that is other than himself - and constitutes, at the first level, the other in the mode: alter ego. ${ }^{47}$

In order to understand the manner by which the other is there-for-me, Husserl contentiously proceeds by analyzing the peculiar sense by which objective nature is there-for-myself. This is not to say that Husserl will characterize the other as a mere object in the world. To the contrary: while the other is excluded by definition from the constitutive activity of the intentional ego, the other is there-for-me as another subject for whom the world is constituted - in the same way that the world is constituted for me by my own egoic activity. Hence, the other is alter ego. Let us investigate the phenomenological structure of this mirroring.

For Husserl, the other derives its sense by way of "an apperceptive transfer from my animate organism ... an 'analogizing' apprehension." ${ }^{48}$ In order to understand this transfer of sense, we must first analyze the essential structure of the ego's sphere of ownness. In the first place, the ego discovers its own intentionality - a preeminent intentionality that determines the ego as an exclusive monad. The ego constitutes its own primordial world independently of other egos. Next, it finds various life processes - cognitive, emotional, biological, to name a few - with correlative unities constituted therein. To be sure, the objective-sense of the world as there-for-everyone is excluded within this second reduction. Yet, even here, objectivity remains an essential aspect of the ego's individual immanence by way of the unique phenomenon of somatic kinesthesia. As Husserl tells us, not all modes of consciousness are modes of self-consciousness: the ego has, as a determining aspect of its own concrete being, an intentionality that enables it to wholly transcend its own being. ${ }^{49}$ This is what is called affectivity. To be specific, the ego inhabits a particular body through which it perceives the world; hence, the body's affective status as flesh. But, simultaneously, the ego is affected by its own body; that is, it is self-affected. The body therefore is given as a first transcendence that grounds the secondary transcedency of objects, which are perceived heteroaffectively. Thus, affectivity harbors a two-fold sense: the ego is a psychophysical unity that not only experiences the transcendent world but also experiences itself experiencing the transcendent world. The second reduction boils down to this: I not only feel (the world) but also feel that I feel; in this precise manner, I am aware of myself. With this understanding of the affective nature of the ego's individual flesh, I discover other phenomenon, other animate organisms, which behave as if they are affected in the same way. Thus, I suppose that they are monadic egos too - namely,

${ }^{47}$ Husserl, Cartesian Meditations, op. cit., p. 100.

${ }^{48}$ Husserl, Cartesian Meditations, op. cit., p. 110-111, my emphasis.

${ }^{49}$ Husserl, Cartesian Meditations, op. cit., section 48. 
that they are psychophysical unities that feel themselves even as they are affected by the outside world. This is the precise sense that is transferred when the self purports to "analogously apprehend" the other.

Here, let us canvas a series of objections to Husserl's "intersubjective reduction." We do not wish to dwell on these objections except in view of delimiting certain differences between the intentionality of love and the objectifying intentionality of scientific knowledge.

First objection: despite his aim to explicate the constitutive-sense by which the other enters into the field of experience, Husserl does not uncover an originary presentation of the other. Rather, he ends up with a non-originary presentation, an appresentation, which is made "co-present" along with the corporeal presence of another animate organism. For Husserl, this is what we mean when we say that the other is there "in person." This unique appresentation excludes the possibility of future verification - unlike the appresentation of the absent profiles of a given objectivity, which may nonetheless be made present by a future intuition. This is not to say that the other is intellectively inferred; rather, the other is experienced as alter ego through a passive synthesis of association whereby the originary presentation of certain affective behaviors in an animate organism motivates us to co-intend another ego. Nevertheless, Husserl's theory of empathy can only lead to the indirect recognition of the other. Love, by contrast, purports to open up knowledge of the other, which is direct recognition not mere inference by analogy.

Second objection: confronted with this impasse, Husserl can only give recourse to the intersubjective sense that is inscribed within objectivity. The robust sense of the world's objectivity is an immanent transcendence that inheres in the "intersubjective sphere of ownness," which is to say that only the "community of monads ... constitutes the one identical world." 50 The independent yet confirmatory constitution of worldly objects by other egos implies that the sense of the world as there-for-everyone is superadded to the primordial sense of the world as there-forme. This forces a curious inversion in Husserl's analysis of the experience of another. Whereas Husserl's leading clue is the other as subject for the world in $\S 43$ of the Cartesian Meditations, Husserl circumscribes his analysis of intersubjectivity as contributing to the phenomenological foundations of the objective world ( $\$ 49)$. The theory of empathy is thus superseded by the theory of the co-constituted knowledge of the scientific community. Thus, we might think of this reduction less as a second reduction but more as a reduplicated and reinforced transcendental reduction (objectivity discovered as constituted by intentional consciousness). As a strange consequence, the other becomes known by way of the ego's clear and distinct perception of the objective world, albeit confirmed by the universal scientific community. It is no wonder that we cannot arrive at an originary presentation of the other. Nonetheless, this inversion begs a fundamental question: can we hope to arrive at knowledge of other subjects by way of the horizon of objectivity? It seems that, in order to reach pure alterity, we must expand the horizon of classical phenomenology. Love, if it is to mean anything at all, must take into account the distinctively subjective dimension of the other.

${ }^{50}$ Husserl, Cartesian Meditations, op. cit., p. 107. 
Third objection: Husserl's recourse to scientific objectivity at the start of the intersubjective reduction belies his unjustified commitment to the primacy of theoretical consciousness. Despite the plurality of modes of worldly existence, Husserl consistently affirms the foundational character of the objectifying act - an act that subtends all modes of intentional consciousness. This act constitutes objects through a continuous synthesis of identification whereby the object is experienced as a transcendent self-identical entity. Husserl is explicit:

Once we have laid hold of the phenomenological task of describing consciousness concretely, veritable infinities of facts - never explored prior to phenomenology - become disclosed. They can all be characterized as facts of synthetic structure, which give noeticnoematic unity to single cogitations, in themselves (as concrete synthetic wholes) and in relation to one another. ${ }^{51}$

Note well: all are characterized as synthetic; every region of being possesses an objective character. Now, even though the Sinngebung must be confirmed by an intuition, constitution renders transcendent objects immanent aspects of intentional consciousness. The formal law of synthesis eliminates the alien character of certain transcendencies. And, it also presupposes that every region of being comes forth in the manner of preformed self-identical entities - only to be uncovered by intentional consciousness. Husserl is well aware that, by submitting the other to the constitutive activity of consciousness, the otherness of the other would thereby be reduced to a moment of the self; hence, he admits that the other cannot be given originally to experience. ${ }^{52}$ And yet, as quoted earlier, Husserl believes that, by means of the ownness of the transcendental ego, the other is constituted in the mode of alter ego. This is not to criticize the passive synthesis of association whereby the sense of animate organism is transferred to certain bodies. This association is unavoidable, even if it must be ultimately accepted as true. However, we must be attentive to the following law of phenomenology: the exclusive, monadic existence of the other (as a unique individual) cannot be synthesized by the self's constitutive activity. Wasn't Husserl's first discovery of the fifth Cartesian Meditation the exclusive, monadic sphere of ownness? Our own ego can be self-perceived precisely because it is our own; the ego of another cannot perceive it. That is, the ego cannot reach the other according to its own power of constitution - and vice versa. Thus, it seems that, if love is to arrive at a genuine experience of the other (irreducible to the theoretical cognition), it must go beyond the objectifying act.

Let us take stock and delineate certain requirements for a successful theory of love. By definition, love gives knowledge of the other - at the limit of experience wherein consciousness reaches pure alterity. Love does not merely reflect the ego's personal preferences and arbitrary sentiments. Yet this does not imply that the other is represented according to the horizon of objectivity. The other is precisely a subject, irreducible to intentional constitution. In order for the other to appear, love

${ }^{51}$ Husserl, Cartesian Meditations, op. cit., p. 41.

${ }^{52}$ Husserl, Cartesian Meditations, op. cit., p. 109. 
must therefore transcend the theoretical attitude of scientific cognition. How is this possible, especially considering Husserl's commitment to the notion that an objectifying act must subtend every intentional rapport with the world? As our leading clue, let us highlight an essential feature of the scientific attitude and juxtapose it with love.

For Husserl, the meditating ego can uncover the genuine sense of a given phenomenon only from the perspective of the disinterested transcendental onlooker. To be sure, when the natural ego perceives an object, the ego is existentially engaged and the perception takes spatiotemporal form. However, in order to uncover the underlying noetic-noematic unity of the cognitive act (that is, in order to explicate the sense of the object), the ego must establish itself as a "non-participant onlooker." 53 This claim is motivated by Husserl's attempt to purge phenomenological reflection of potential prejudice; however, in the process, he has the tendency to obscure various existential characteristics that seem to be involved in the constitution of certain phenomena, such as love. It is telling that, when Husserl moves from the primordial transcendency of the ego's own world to the higher transcendency of the objective (that is, intersubjective) world, "it is not a matter of uncovering a genesis going on in time, but a matter of 'static analysis."'54 For Husserl, the objective world is already there, already finished, neutrally placed before each and every ego, available only for disinterested analysis. To be more specific, let us highlight two of its features. (1) In theoretical cognition, the will either falls away or it merely serves to confirm the prior achievements of the objectifying act. (2) The affective aspect of consciousness merely serves to provide raw data (i.e. sense-impressions), which are ultimately synthesized by the higher identifying function of the ego. Yet must all phenomena exhibit the static structure of noetic-noematic unity? Or perhaps there are certain experiences (love, e.g.), whose sense requires ongoing existential engagement - affective and volitional.

It seems that, to the extent that the other resists the static constitution of an intentional ego, love requires just such an ongoing existential engagement. Ever since Heidegger, phenomenology has hoped to recover an active and dynamic understanding of being and truth. As such, we will turn towards Heidegger's "existential analytic" in the hopes of recovering an understanding of the other by way of active engagement with the other. As such, we hope to be equipped with a phenomenology of love that is irreducible to theoretical consciousness.

\section{§5: Un-stilling the stream}

As we have seen, reality is manifested according to the theoretical attitude for Husserl; beings appear as mere objects, to be identified in their permanent bodily presence by the mediation of disinterested cognition. "At the height of its gnoseological adventure everything in sensibility means intuition, theoretical receptivity from a distance (which is that of the look)." ${ }^{\prime 5}$ While Husserl broadens

${ }^{53}$ Husserl, Cartesian Meditations, op. cit., p. 37.

${ }^{54}$ Husserl, Cartesian Meditations, op. cit., p. 106.

${ }^{55}$ Emmanuel Levinas, Otherwise than Being, or Beyond Essence, Alphonso Lingis trans. (Pittsburgh, Pennsylvania: Duquesne University Press, 2009), p. 75. 
experience to include the appresentation of categorial intuition within sensation by way of the passive synthesis of association whereby an entity's appearance is contextualized by its categorial dimension, the power of sense-explication belongs by rights to the non-participant onlooker. Although understandable, it is strange and philosophically tenuous to privilege the disinterested, contemplative attitude. We are at the threshold of a twofold objection to transcendental-phenomenology.

(1) Must a doxic thesis subtend every intentional rapport with the world? Does not common, everyday experience tell us otherwise? Are not certain regions of being resistant to constitution in the manner of a theoretical object? Is intellectualism the only philosophically tenable approach to reality? And, does not this theoreticism smack of the subject-object distinction, which phenomenology sought to overcome? The limiting of the scope of manifestation to theoretical objects is explained by Husserl's inattention to modes of phenomenalization. The phenomenal indetermination with respect to the modes of access to the various regions of being led Husserl to consider them as mere objects and therefore as objects of scientific knowledge; that is, the lack of phenomenal specification reciprocally entailed ontological neglect.

(2) Even more striking: does not the privileging of the disengaged theoretical attitude in a philosophy that locates absolute being in lived experience express a deep tension - if not a contradiction - in the heart of the Husserlian enterprise? We are at the heart of the most pointed objection to phenomenology: does not the transcendental reduction disengage the contemplative subject from its lived experiences? Which, of course, begs the question: is it even possible to arrive at lived experience by way of transcendental subjectivity? Attempting to establish philosophy as an Urwissenschaft, Husserl displaced knowledge as the philosophy's starting point (Kant) in order to reflect upon pretheoretical experience. Yet, as Paul Natorp of the Marburg Neo-Kantian School famously objected, is not the very idea of a science of pretheoretical experience impossible? Does not the reflective attitude of scientific inquiry necessarily lead to abstraction (objection 1) and doesn't it necessarily "still the stream" of experience (objection 2)? Hence, in order to develop a phenomenology that is attentive to the unique modes of phenomenalization at the pretheoretical level, we must analyze experience in all of its immediacy.

Heidegger represents an advance in this regard. He challenges the Husserlian primacy of theoretical consciousness while retaining the notion that the very constitution of reality is determined - in its nature and mode of existence - by its meaning for intentionality. Inverting Husserl's notion of categorial appresentation (wherein sense intuition precedes meaning), Heidegger declares that meaning is given prior to objects. That is, worldly-things are given precisely because of the anterior meaningfulness of the world itself, which serves as the immediate context for the derivative meaning of the worldly-thing itself. Shortly, we shall discuss the manner by which the world is a context of meaning because it will direct our analysis of the appearance of the self and the other. However, let us note that "the primacy and immediacy of meaning in the sense of empowering contextualizing, as the most immediate experience of the being of historical life" is the core of the 
mystery of being for Heidegger. ${ }^{56}$ The world (as a complex of meaning) makes possible the being of objects (as situated contextually within the world). Hence, in order to transcend the limitations of Husserlian phenomenology, Heidegger does two things. (1) He analyzes existence according to the ontological difference - the distinction between "that which is" (tools, mere things, etc.) and "the being of that which is" (the world). Being pro-duces beings. (2) Correlatively, instead of uncritically modeling intentionality after theoretical consciousness (transcendental subjectivity), Heidegger interrogates the very being of intentionality; that is, he analyzes the way in which it finds itself always already affected in the world. These decisions will determine the way in which we might understand the existential import of love.

It goes without saying that love was not heavily thematized in Heidegger's work; however, given his engagement with Greek and medieval philosophy, some scholars have identified influences of erotic thinking in his ontology. Theodore Kisiel, for example, has characterized the penultimate draft of Sein und Zeit as an "ontoeroteric draft." This neologism is meant to reflect the conceptual and etymological relationship between questioning ( $\dot{\varepsilon} \rho \omega \dot{\tau} \tau \sigma \iota)$ and $\varepsilon^{\prime} \rho \omega \varsigma$ within the Greek language. It is well known that, while the Eleatic Stranger of Plato's Sophist questions the meaning of the expression "being," Heidegger interrogates the concrete (phenomenological) meaning of the question itself as a formal indication into the meaning of being. At its core, the interrogative comportment to being is at once affective-experiential; hence, the erotic quality of questioning. Especially within the context of Heidegger's phenomenological ontology, "the quest for being first manifests itself on the preverbal erotic level, the $\pi \alpha \theta^{0}$ os which gives rise to the question of being, before it reaches the verbal level of questioning." ${ }^{77}$ That is to say, before the question of the meaning of being is actually posed, the questioning entity is already affected by being, as a pretheoretical experience. That is, having been affected, the question is posed. Thus, it is the first task of phenomenological ontology, as a phenomenology of Dasein, to uncover the sense of this experience. As Heidegger explains it in the penultimate draft, Prolegomena zur Geschichte des Zeitbegriffs (1925), "this affectedness of the questioning entity by what is asked for belongs to the ownmost sense of the question of being itself." 58 It is precisely this affectedness (by and towards being) at the core of the question itself (understood as the pretheoretical erotic experience of wonderment before being itself), which leads us to believe that love emerges in Heidegger's thought as love of being. Let us interrogate its structure, especially as it relates to the appearance of the self and the other.

56 Theodore Kisiel, The Genesis of Heidegger's Being and Time (Berkley and Los Angeles, California: University of California Press, 1995), p. 376.

${ }^{57}$ Kisiel, Genesis, op. cit., p. 544 n.1, my emphasis.

${ }^{58}$ Martin Heidegger, History of the Concept of Time: Prolegomena, Theodore Kisiel trans. (Bloomington, Indiana: Indiana University Press, 1985), p. 148. 


\section{§6: Heidegger: care and ontological dénouement}

If not contemplatively, how might we understand being? Following Parmenides and Heraclitus, for whom "being and thinking exist in unity," Heidegger commences by analyzing the being that is concerned for (and questions) its very being, namely, Dasein. There, he hopes to uncover the meaning of being. Heidegger finds that "Being is precisely what is revealed to Dasein, not under the form of a theoretical concept that one contemplates, but in an internal striving, in a concern that Dasein has for its very existence." 59 Concretely: to-be means to find oneself already affected by the world, already involved with the world, already there in the midst of worldly concerns. According to this prepositional nexus, one's experience of the world is always already meaningful. That is, the $\lambda$ ó $\gamma$ os of the world is found to

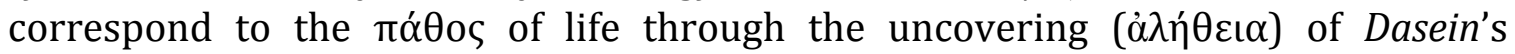
meaningful engagement with the world (intentionality). Hence, as universal phenomenological ontology, philosophy takes its departure from the existential analytic of Dasein. ${ }^{60}$ Let us watch this analysis unfold in order to catch sight of the being of the other.

In order to get at the immediacy of experience, Heidegger treats "being-inthe-world" as the formal indication (formale Anziege); that is, being-in-the-world is the fundamental existential structure of Dasein. The world, as a philosophical concept, is opposed to the naive view of the world, as the sum of all beings in general. This would remain the ontic phenomenon of the world. Conversely, the philosophical concept of the world is to be determined ontologically. Taking his bearings from practical activity, Heidegger finds that being-in-the-world means to exist "in-view-of," which is to imply a teleological structure. Tools (Zeuge) are not objects in the manner of "mere things" to be contemplated or represented; thus, objective presence-at-hand (Vorhandenheit) does not reveal the "toolish" mode of existence of the tool. On the contrary, the tool is made manifest by being handled, by

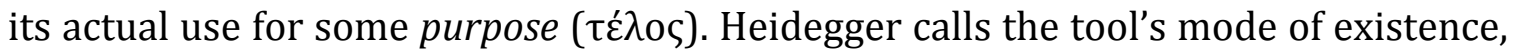
Zuhandenheit ("handiness" or "handlability"). The practical intentionality of Dasein therefore reveals the sui generis structure of Zuhandenheit, and does not merely reveal an abstract eidos of a given tool. ${ }^{61}$ And yet Zuhandenheit is ontologically conditioned by the world. What then is the ontological sense of the world? We may take functionality as our leading clue. As functional, tools exist in view of something, which, in turn, is in view of something else. It is precisely this network of referrals that makes possible the Zuhanden mode of existence of tools. However, this meaning-complex of interrelations must terminate in something, which is "in-viewof-itself." This is the human person (Dasein), which refers innerworldly beings to itself in such a way that it is fundamentally concerned with its very own being. "The World is nothing other than this 'in-view-of-itself' where Dasein is involved with its own existence and in relation to which the encounter with the handlable can come

\footnotetext{
${ }^{59}$ Emmanuel Levinas, "Martin Heidegger and Ontology," Committee of Public Safety trans., Diacritics 26.1 (1996), p. 18, my emphasis.

${ }^{60}$ Martin Heidegger, Being and Time, Joan Stambaugh trans. (Albany, New York: State University of New York Press, 1996), §7. ${ }^{61}$ Levinas, "Martin Heidegger and Ontology," op. cit., pp. 19-20.
} 
about." 62 The philosophical concept of the world is therefore the totality of referrals and the ontological condition of tools.

The in-view-of structure proper to Dasein's being-in-the-world is precisely the being of beings, the very meaning of existence. To some degree, Heidegger is giving a phenomenological and pragmatic interpretation of Aristotle - a move that determines the shift away from Husserlian theoreticism. In Nicomachean Ethics I.7, Aristotle states that "the good and the 'well' is thought to reside in the function." Certainly, when we read these lines, we are led to think that Aristotle is simply applying the teleological principles of his Physics to human action. "Nature creates nothing without a purpose, but always the best possible in each kind of living creature by reference to its essential constitution." ${ }^{63}$ However, we might also view Aristotle's teleological cosmology through a phenomenological lens. The essential constitution of something is manifested in the excellent performance of its respective function. That is to say, the experience of a well functioning thing reveals its form; and, generally speaking, activities which lead to flourishing manifest essential features of reality. This is perhaps one reason for which Aristotle claims in Posterior Analytics II.11 that a demonstration by way of final causality issues in genuine knowledge - knowledge gained through experience, not by abstraction. We see then that the understanding of being is obtained only by participating in the very project of existence, namely, by being-in-the-world. Having integrated epistemology with ontology, we have simultaneously uncovered the dynamic and active understanding of reality as opposed to the static and disinterested contemplation of reality. As an active structure of signification, the Sein of the seiendes is precisely the luminosity of existence.

Stepping into the light of being, we may ask our central question: how does Dasein encounter the other? Again, Heidegger inverts Husserl's notion of categorial appresentation (in this case, the other "in person" that is inferred along with the intuition of an animate organism): worldly objects, in their existence-sense, derive their meaningfulness from other Daseins, which are the more original existential presence. Stated otherwise, the other is "encountered" as the kind of being (i.e. another Dasein) for whom the world is immediately given as a context for praxis; that is, encountered as another being-in-the-world. Heidegger explains:

The others who are "encountered" in the context of useful things in the surrounding world at hand are not somehow added on in thought to an initially merely objectively present thing, but these "things" are encountered from the world in which they are at hand for others... the kind of being of the existence of the others encountered within the surrounding world is distinct from handiness (Zuhandenheit) and objective presence (Vorhandenheit). ${ }^{64}$

62 Levinas, "Martin Heidegger and Ontology," op. cit., p. 22.

${ }^{63}$ Aristotle, On the Gait of Animals, A. S. L. Farquharson trans. http://classics.mit.edu/Aristotle/gait anim.html, section 2. ${ }^{64}$ Heidegger, Being and Time, op. cit., §26. 
Worldly-beings are Zuhanden for others, as well as for me; and this is a primal fact of existence. Let us be clear that the other is not a categorial determination (i.e. as an inferred duplicate of my own subjectivity) but is an existential determination: the other is "understood" as being intimately engaged in the world like every other Dasein. Even so, the other is not theoretically delimited by "locative adverbs and personal pronouns" (i.e. as a "you there") but is pretheoretically experienced as involved in the same surrounding world - using the same tools, walking the same earth, working the same field, etc. The self and the other are involved in the similar preoccupations precisely because the world is the same context for the unfolding of the being of any Dasein. Thus, I discover myself as well as others by way of the surrounding world because the world of Dasein is always already a world that is shared. "The world of Dasein is a with-world. Being-in is being-with others. The innerworldly being-in-itself of others is Mitdasein." 65 For that very reason, the other counts as an equiprimordial existential determinant of Dasein's very own world, very own being.

And yet, if Dasein appears by way of its involvement with the world, are not the self and the other rendered indifferent vis-à-vis one another? That is to say, qua Dasein, the other takes care of itself by being involved with the surrounding world; it is of no concern to me. And yet, for Heidegger, the Dasein of the other is a matter of concern (Fürsorge) - a concern that can exhibit two possible extremes. On the one hand, concern can "take the other's 'care' away from him and put itself in his place in taking care, it can leap in for him"; on the other hand, concern can "leap ahead of [the other], not in order to take 'care' away from him, but to first to give it back to him as such."66 Instead of treating the other as another tool or objective presence amongst many, instead of appropriating another's projects to oneself, authentic concern enables the other to take care for himself or herself - presumably by way of communication or, even better, by way of education (e-ducere). Comportments of indifference vis-à-vis the other are deficient modes of authentic concern, which liberates the other to its own Dasein.

Being for-, against-, and with-one-another, passing-one-another-by, not-mattering-to-one-another, are possible ways of concern... [Beingfor-the-other] essentially pertains to authentic care; that is, [pertains to] the existence of the other, and not to a what which it takes care of, helps the other to become transparent to himself in his care and free for it... This authentic alliance first makes possible the proper kind of objectivity which frees the other for himself in freedom. ${ }^{67}$

Authentic concern for the other therefore enables Mitdasein to immerse itself in the functionality and objectivity of worldly-things because it liberates every Dasein to authentically take care (Besorgen) in the surrounding world; that is, on its own.

65 Heidegger, Being and Time, op. cit., §26.

${ }^{66}$ Heidegger, Being and Time, op. cit., §26.

${ }^{67}$ Heidegger, Being and Time, op. cit., §26. 
Can we say that love (as an affective experience of the other) emerges for Heidegger by way of the phenomenon of authentic care for the other? ${ }^{68}$ In order to answer this question, we must note the importance of the affections in Dasein's selfdisclosure. The abovementioned analyses only sketch the existential constitution of being-in-the-world at a formal, structural level. But, for Heidegger, Dasein is also its own disclosure: in contradistinction to the traditional separation of existence and knowledge whereby being is revealed to theoretical consciousness from a distance, $\dot{\alpha} \lambda \eta \dot{\theta} \theta \varepsilon \_$(phenomenological truth) consists "in the exposition of being to itself, in self-consciousness... The subjective movement of cognition thus belongs to being's very essence." ${ }^{9}$ For Heidegger, epistemology is fully integrated with ontology such that "understanding of being is itself a determination of being of Dasein."70 Concretely: Being is revealed to Dasein - through its very existence - in a certain attunement or affective disposition (Befindlichkeit). Affections are not psychological states that are superimposed upon theoretical consciousness as a sort of confirmation of the accomplishments of the cognitive subject. To the contrary, Dasein's affective dimension has a double existential significance: "[it] has always already disclosed being-in-the-world as a whole and first makes possible directing oneself toward something." ${ }^{1}$ Thus, as revelatory modes of being, the affections are simultaneously modes of understanding.

Again, might we consider love's affective dimension as the basis for Dasein's attunement to Mitdasein? Is love the Mit-befindlichkeit, unaddressed by Heidegger? While Mitdasein is existentially constitutive for being-in-the-world, Heidegger is unable to liberate (that is, disclose) the self and the other from the They (das Man). As we have seen, Heidegger tries to liberate the self and the other by way of the "with-which" existential constitution of Dasein's surrounding world (Mitdasein); that is, by uncovering the other's authentic comportment to the world, immersed as they are in the functions of worldly work. Heidegger is clear, however: on the basis of Fürsorge, the "who" of everyday Dasein is the anonymous neuter of the "they," which is to say that "anyone" can function in the surrounding world.

They are what they do... In utilizing public transportation, in the use of information services such as the newspaper, every other is like the next. This being-with-one-another dissolves one's own Dasein completely into the kind of being of "the others" in such a way that the others, as distinguishable and explicit, disappear more and more...

68 Interestingly, in a footnote of Being and Time, p. 403-404 n.6, Heidegger quotes Pascal and Augustine favorably, for whom the affections (charity, in particular) function to disclose certain regions of being ("divine things," in the case of charity). To be sure, Heidegger thinks that these thinkers fail to plumb the existentialontological depths of the affections. Nevertheless, the affections can be given their appropriate existential sense by way of phenomenological research. Let us see if love can be given its appropriate existential sense by way of Heidegger's analysis. 69 Levinas, Otherwise than Being, op. cit., p. 28 and 61, my emphasis.

70 Heidegger, Being and Time, op. cit., §4.

${ }^{71}$ Heidegger, Being and Time, op. cit., §29. 
Everyone is the other, and no one is himself. The they, which supplies the answer to the who of everyday Dasein, is the nobody to whom every Dasein has always already surrendered itself, in its beingamong-one-another. ${ }^{72}$

Ontically, the self is only a modification of the They, the Anyone. I may be a farmer but anyone can be farmer. As an existential determinant of Dasein, the other (qua Mitdasein) is discovered not in itself but in the manner of its functioning within the world. Even thought the other might appear as an anonymous neuter that independently comports itself to the world, the other does not appear as a discrete individual that is irreducible to its functional relation to the world (that is, as a self distinct from the others in the They). In Heidegger's ontology, love can emerge only as an ontic disposition towards the everyday, average other - perhaps, we may call it a beneficent friendship ( $\varphi\left(\lambda i{ }^{\alpha} \alpha\right)$, which establishes the proper conditions for the other's absorption in worldly affairs (Besorgen). But Dasein can appear to itself if not to another, which, as we shall see, is the reason for the other's basic occlusion.

For Heidegger, Dasein is liberated from the everydayness of the They only by being authentically delivered to itself, where "the 'world' can offer nothing more, nor can the Mitdasein of others." ${ }^{73}$ How does Dasein know its authentic situation? The affections "are modes of self-understanding, that is to say, of being right-there."74 How so? Dasein means to exist dynamically. If Dasein is in-view-of-itself, then "existence has the appearance of anticipating itself."75 Dasein is beyond itself "in project." At the same time however, "in existing, Dasein is always already thrown into the midst of its possibilities and not positioned before them." 76 Hence, we find time and distention at the very heart of existence: Geworfenheit ("thrownness") and Entwurf ("project-in-draft") reflect the very temporalization of existence itself. "The whole paradox of this structure, in which existence in view of itself presents itself as essentially ecstatic, is the very paradox of existence and time."77 It is precisely this ecstatic structure that constitutes the affectedness of "being-right-there" (Dasein). That is, Dasein is affected by its very own being in such a way that it is projected out in view-of-itself in dynamic self-transcendence. Yet the matter becomes more pressing: how is Dasein concretely revealed to itself? Specifically, which affective disposition constitutes being's self-understanding?

Anguished care reveals Dasein's authentic situation to itself. As we have seen, the authenticity of being a self is occluded at the ontic level because Dasein is absorbed in innerworldly being. But the phenomenon of Angst presents the nothingness of worldly objects and brings Dasein back to its isolation, back to its very potentiality-for-being-in-the-world, "back to the bare possibility of existence."78

72 Heidegger, Being and Time, op. cit., §27.

${ }^{73}$ Heidegger, Being and Time, op. cit., §40.

${ }^{74}$ Levinas, "Martin Heidegger and Ontology."

75 Levinas, "Martin Heidegger and Ontology," op. cit., p. 23.

${ }^{76}$ Levinas, "Martin Heidegger and Ontology," op. cit., p. 24.

${ }^{77}$ Levinas, "Martin Heidegger and Ontology," op. cit., p. 22, my emphasis.

${ }^{78}$ Levinas, "Martin Heidegger and Ontology," op. cit., p. 30, my emphasis. 
Angst is thus phenomeno-logical: Angst discloses Dasein's ownmost being as care (cura, Sorge) - not concern for an ontic self but projection towards authentic being. In anguished care, Dasein exists authentically as thrown and projecting - not according to the secondary possibilities of transcendent worldly objects but according to the highest possibility of sheer self-transcendence in-view-of-itself. Incidentally, Heidegger is able to integrate the theory of knowledge with ontology because he finds the transcendence of knowing to be rooted in the illuminating movement from beings to being itself - originary self-transcendence. Nevertheless, the transcendence of entities vis-à-vis consciousness is derivative upon this originary transcendence, which is to say that entities are meaningful only to the extent that they support the bare existence of Dasein. By giving intentionality an ontological foundation, Dasein is essentially nostalgic for ontological self-completion. To-be-in-the-world is to strive to be. Thus, in the ontologically significant attunement of Angst, we come full circle: Sorge amounts to Dasein's concern for its very being, which amounts to an understanding of the mystery of existence itself. And, in Angst, it seems that Dasein, in its authentic aloneness, is more existentially foundational than Mitdasein.

\section{§7: Gigantomachy for/of Being, or self-love}

Heidegger's philosophy can best be characterized as "ontological solipsism," in a sense homologous to Husserl's transcendental solipsism. How so? Angst is an ontologically significant phenomenon not only because it throws Dasein into its authentic potentiality-for-being-in-the-world, unabsorbed by innerworldly beings, but also because Angst "individualizes and thus discloses Dasein as 'solus ipse."'79 To be sure, Dasein exists in the world; yet it cares for its very being on its own (authenticity). Thus, in anguished solicitude, Dasein's "ownness" - which Heidegger calls Jemeinigkeit (mineness) - is revealed. Let us be clear: Angst does not isolate a subject that stands before the world (as in traditional metaphysics). To the contrary, it reveals Dasein's authentic being-in-the-world, existentially engaged in its project of being; that is, on its own and disentangled from the They. This is not to deny the existence of other Daseins. For, as we know from the existential analytic, the other impacts Dasein's being-in-the-world in the mode of Mitdasein; yet the other does not otherwise affect Dasein's essential relation to itself, its persistence in existence. Therefore, Heidegger's ontological solipsism appears (ontically) as self-love; or, to take a liberty with the terminology, Dasein's self-disclosure appears in the mode of "being-affected-by-and-towards-one's-very-own-being." Which is to say that the deepest existential feature of Dasein is affection from itself, towards itself.

And yet we must be clear: self-love is an ontic phenomenon. While Dasein is attuned to ontological difference through Angst, it is attuned to its own being through its love of life. Even though this is not Heidegger's phraseology, we are taking our leading clue from Levinas' understanding of Heidegger's existential analytic. "The love of life does not resemble the care for Being, reducible to the comprehension of Being, or ontology. The love of life does not love Being, but loves

${ }^{79}$ Heidegger, Being and Time, op. cit., $§ 40$. 
the happiness of being." 80 In the next section, we will show that love cannot be thought ontologically, that is, as love of Being. However, it is beyond doubt that love harbors ontic significance: love of virtue, of vice, of family, of nation, of humanity, etc. Love - love of one's own life, to be precise - takes place within the horizon of worldly meaning. That is to say, because Dasein's being-in-the-world is intrinsically meaningful, it loves its very own project of being. Absorbed in worldly concerns, Dasein is at-home; thrownness is not absurd. Innerworldly being does not primordially appear as threatening or menacing. To the contrary, because innerworldly being is ontologically conditioned by Dasein, it appears originally as fulfilling - as that which can satisfy the project of being (Entwurf). Thus, the ontic phenomenon of enjoyment is derivative upon Dasein's essential being-at-home-inthe-world, which is the contextual habitat of an autochthonous ego at work in the project of its very existence. And yet what about needs, for which humans tend to suffer? Don't needs reveal deficiency in the heart of being? To the contrary: need is being's plenitude vis-à-vis itself. Needs express Dasein's inner dynamism-selftranscendence in the project of being. Ontic needs (food, clothing, shelter, education, sports, friendship, etc.) are therefore a source of joy because they create the space for Dasein's continued project of being; thus, the intelligibility and coherence of the popular phrase, "love of work." It is unavoidable: one loves oneself by living life.

Love renders the other's ownmost being opaque, albeit in a qualified sense: in loving life, in living self-love, other Daseins remain hidden in their authentic ownness, revealed only in the everyday mode of Mitdasein. The other cannot appear in its ownness because Dasein's self-disclosure is in-view-of-itself; that is, beingright-there is to anguish after one's own being, not another's. To be sure, the ontic phenomenon of being-towards-another (Fürsorge) reveals a basic existential determinant of Dasein's ownmost being, namely, Mitdasein. Factically, Dasein persists in a shared world; and yet this is not a value-laden claim. That is, the sharedness of the world does not reveal responsibility for others; the other does not even appear in its own right. To the contrary: Mitdasein is simply an ontological condition of factical existence. Dasein is for-others only in-view-of-itself. Note well, there is no room for the is-ought distinction in Heidegger's ontology; the unconcealment of being reigns supreme. Nevertheless, let us confirm the following: beings persist in a shared world, a world of the anonymous They, each being going about its work of being, sometimes authentically in anguished solicitude, never authentically anguishing over the other. Dasein's self-disclosure, its persistence in being, occludes the other. As we shall see, this essential blindness is the (phenomenological) correlate to a mysterious but understandable onticoontological violence. Hidden from each other, every Dasein is caught up in the drama of being's self-interest - the war of all against all. We are beginning to catch sight of an ontological impossibility: Dasein can't genuinely love another because being primordially loves itself.

Dasein's self-love, Dasein's self-disclosure, is determined by its essential relation to itself - which, as we shall see, expresses the ontological event of Being

80 Levinas, Totality and Infinity, op. cit., p. 145, my emphasis. 
itself. Concretely: Dasein is affected towards itself, loves its work of life, because of its inner dynamism. Levinas explains:

Esse is interesse... [Being is interestedness]... It is confirmed positively to be the conatus of beings. And what else can positivity mean but this conatus? Being's interest takes dramatic form in egoisms struggling with one another, each against all, in the multiplicity of allergic egoisms which are at war with one another and are thus together. War is the deed or the drama of [Being's] interest. No entity can await its hour. They all clash, despite the differences of the regions to which the terms in conflict may belong. [Being] thus is the extreme synchronism of war. Determination [of beings, eidos] is formed, and is already undone, by the clash. ${ }^{81}$

Levinas has pinpointed two features of the existential analytic: ontologically, beings are related to themselves in such a way that they dynamically strive to persist in their very being; ontically, this is expressed as war, beings struggling against other beings. Thus, in a sense, Heidegger is the mystical priest of the survival instinct; that is, by way of phenomenology, Heidegger unites Hobbes' ontic science (of the bellum omnium contra omnes) with Spinoza's ontology (of the conatus essendi). This onticoontological violence corresponds to a deep feature of Heidegger's thought: ontological difference is blind.

Being is indifferent to everything. Specifically, being's interest is indifferent to the eidetic structures of the various regions of being; and yet being's interest is precisely the ontic difference between being and non-being. As we shall see, the conatus submerges quiddity ("whatness") in view of sheer quoddity ("thatness"). Nevertheless, the unfolding of being's interest has become a uniform characteristic of every being, deployed without reference to eidetic difference. Thus, we begin to see that the anonymity of Dasein, lost in the everyday They, returns more forcefully under the neutral unfolding of being's interest. In other words, while Heidegger hoped to allow the self and the other to appear out of the They through an attunement to the equiprimordial existential structure of Mitdasein, the self and the other have been ontologically dissolved into the sheer fact of being's interest. Levinas called this the "philosophy of the neuter." As such, we are not surprised by the mysterious vacillation in Heidegger's thought-swinging from onticoontological violence (i.e. the concrete self-love of a punctuated ego to the occlusion and the detriment of the other) to ontological monism (i.e. the homogenous unfolding of being's interest). Beings are like atomistic nodes through which the very event of being anonymously takes place.

The conatus is expressive of an ontological monism: "beings persist" because "Being is." Rejecting the transcendental reduction, Heidegger's phenomenological analyses of concrete life enable us to behold the absoluteness and self-sufficiency of Being itself. This was Levinas' insight as early as 1935 in On Escape, which we quote now in detail:

${ }^{81}$ Levinas, Otherwise than Being, op. cit., p. 4. 
The very fact of existence refers only to itself. It is that through which all powers and all properties are posited... The fact of being is always already perfect. It is already inscribed in the absolute. ${ }^{82}$ Being is: there is nothing to add to this assertion as long as we envision in a being only its existence. This reference to oneself is precisely what one states when one speaks of the identity of being. Identity is not a property of being, and it could not consist in the resemblance between properties that, in themselves, suppose identity. Rather, it expresses the sufficiency of the fact of being, whose absolute and definitive character no one, it seems, could place in doubt. ${ }^{83}$

While imbuing Being with an active resonance, Heidegger's position is nonetheless tributary to Parmenides. Being is an impersonal absolute (Parmenides), which dynamically completes the work of being (Heidegger). And yet this entails a paradox: ontic difference (that is, the self-identity of a given entity) is ontologically conditioned by Being's self-identity; and yet ontic difference (whether eidetic or individual, it does not matter) is at war with itself because being unfolds itself without reference to ontic difference. Thus, the union of Heraclitus' unity of opposites with Parmenides' ontological monism within Heidegger's existential analytic is no contradiction. Ultimately, it is no wonder then that ontological difference is blind: the very fact of existence refers only to itself.

Here, we may ask two questions. (1) Can we love being? Being's interest, which is Dasein's self-love, unfolds itself, indifferent to ontic difference. If self-love is founded on being's interest, how can anyone love himself or herself by way of the anonymous unfolding of being's interest? Self-love, so it seems, would have to refer, at a basic level, precisely to the self. (2) Can we even be attuned to pure Being? As we shall see, the answer to this question will determine our answer to the first.

\section{§8: Love of Being: an impossibility for thought, or self-alienation}

Angst, Heidegger tells us, has an "uncanny" feeling because it discloses the insignificance of innerworldly being. This is not a cause for worry in Heidegger's view. In fact, Angst brings Dasein before beings, revealed under the dimension of ontological difference (beings in their being). That is, Angst throws Dasein into its authentic being-in-the-world.

Now, however, what falling prey [to the "world"], as flight, is fleeing from becomes phenomenally visible. It is not a flight from innerworldly beings, but precisely toward them as the beings among which taking care of things, lost in the They, can linger in tranquilized familiarity. Entangled flight into the being-at-home of publicness is flight from not-being-at-home, that is, from the uncanniness which lies

82 Emmanuel Levinas, On Escape, Bettina Bergo trans. (Stanford, California: Stanford University Press, 2003), p. 56-57.

${ }^{83}$ Levinas, On Escape, op. cit., p. 51. 
in Dasein as thrown, as being-in-the-world entrusted to itself in its being. This uncanniness constantly pursues Dasein and threatens its everyday lostness in the They, although not explicitly. This threat can factically go along with complete security and self-sufficiency of the everyday way of taking care of things.

Let us be clear about an interpretive decision. For Heidegger, the "uncanny" feeling of Angst does not disclose the meaninglessness of Dasein's individualized, pure potentiality-for-being-in-the-world. Geworfenheit is not considered by Heidegger to be absurd. To the contrary: the uncanniness of Angst is meant to unsettle, meant to disentangle Dasein from the They, so that Dasein can authentically embrace its own being-in-the-world. Over the next few paragraphs, we will privilege an alternative decision. In its oppressive uncanniness, Angst suggests that the sheer positing of existence (i.e. Being itself) is insufficient and absurd for the human self and Being's feigned absoluteness unfolds as the most basic form of self-alienation. ${ }^{84}$ Let us elaborate.

Angst, which is attuned to ontological difference, "is so near that it is oppressive and stifles one's breath... [It] is absolutely unhoped for and not to be perdured-[it] estranges." ${ }^{85}$ As we have seen, Angst manifests nothingness as a flight towards innerworldly being, which Dasein lovingly embraces as the very solidity of being-in-the-world. And yet, behind this attunement, Dasein senses the silent but terrible amplitude of pure Being, which alienates Dasein from itself. It is no wonder then that Dasein is anxiously estranged from the nothingness of being paradoxically, the situation of authenticity - towards entanglement in the world. This suggests that, while authenticity is an essential possibility for Dasein, Sein (being qua being) is tainted in its very core.

Being itself (Sein) is not a theoretical construct that is reached by an excessive ecstatic-erotic disposition towards abstraction (scholastic love of being). Through his analysis of the Grundstimmung (fundamental mood) of nausea in On Escape, Levinas had recognized the horror, the anonymity and the absolutely binding presence of "pure being." In the situation of Geworfenheit, Levinas sees clearly that "Dasein is riveted to its possibilities ... its 'right-there' is imposed upon it." 86 Now, for Heidegger, this does not imply the congealing or solidifying of being in some sort of immobile hypostasis. On the contrary, being - "in a verbal sonority," as Levinas calls it - is projected beyond itself in a dynamic transcendence. Yet, in nausea, Levinas finds precisely a situation where being is paralyzed to the point of immobility. ${ }^{87}$ Whereas Angst signals the ontological difference through the nothingness of innerworldly being, nausea is "the very experience of pure being." 88 That is, in the very moment of nausea, Being is experienced in all of its absoluteness and self-sufficiency and yet is experienced as a terrible, absolutely binding presence.

\footnotetext{
84 To be clear, Angst only suggests it; nausea shows it.

85 Heidegger, Being and Time, op. cit., $\$ 40$.

86 Levinas, "Martin Heidegger and Ontology," op. cit., p. 24.

87 Levinas, On Escape, op. cit., p. 67.

${ }^{88}$ Levinas, On Escape, op. cit., p. 67.
} 
That is, Dasein's sheer fact of existence is imposed upon it and, for that very reason, is unbearable; anguished solicitude is meant to deliver freedom but it comes as threat. The inner structure of the self-positing of being signals not only the selfsufficient plenitude of being but also the need to escape. In accordance with this inner structure, the philosophical task is determined anew. Having renewed "the ancient problem of being qua being, ... the need for escape ... leads us into the heart of philosophy."89

The horror of nausea - and, by derivative implication, the uncanniness of Angst - decisively shows that being can't be loved. This is not to imply that the psychological disposition of anxiety overwhelms one's capacity to love. To the contrary: we are making an ontological claim by way of Befindlichkeit. Again, Angst manifests the nothingness of being as Dasein's flight towards beings. Attuned to ontological difference, Angst manifests the hidden energy of life. And yet nausea manifests pure Being as the brutal fact of existence, a fact that is neither to be accomplished nor overcome. That is to say, beings (under the aspect of ontological difference; that is, beings in their being) are experienced as a thrown projecting, as an essential dynamism; beings (under the aspect of pure Being; that is, in the sheer fact of their existence) are experienced as absolute and self-sufficient, as perfectly posited identities. By implication, Dasein can love itself in its own work of being-inthe-world; that is, love appears as Dasein's being-affected-by-and-towards-its-verybeing. However, Dasein does not love the sheer fact of its existence; to the contrary, it is nauseated by it and, a fortiori, it is alienated by it (which is to say that authenticity is nauseating). To summarize by quoting Levinas again: "The love of life does not resemble the care for Being, reducible to the comprehension of Being, or ontology. The love of life does not love Being, but loves the happiness of being." Dasein can't love Being itself for Being simply is. Not only experienced as horrible, Being is experienced as the very irrevocability and immovability of sheer existence. Love thus cannot be thought ontologically.

Are we to give up the project of establishing the erotic intelligibility of the world? Or are there hidden vistas in the existential analytic? As we recall, for Heidegger, Dasein's being-in-the-world displays inherent meaning. Now, under the shadow of Levinas' existential analytic, Being strikes Dasein as nauseating, alienating and, perhaps, meaningless. How have we arrived at this situation? Being and Time is a quest for the meaning of being by way of explicating the internal sense of the very question. Heidegger is undoubtedly aware that, because it is formal and universal, the question tends towards empty abstraction. Thus, Heidegger is clear: "Being is always the being of a being." 90 The meaning of being must always be rooted in the explication of a concrete being. Phenomenologically, the task is to show beings in their being. As such, the question of the meaning of being remains the most concrete question. And yet Heidegger's corpus tends towards questioning the meaning of being as such, in general and by itself. Don't these two poles of inquiry work at odds with one another? Does the quest for Being itself run counter to an existential analytic based upon ontological difference (that is, being concretely

${ }^{89}$ Levinas, On Escape, op. cit., p. 56.

90 Heidegger, Being and Time, op. cit., §3. 
united to beings)? Does Being harbor meaning apart from beings? What can Being itself really mean? Levinas tells us: pure Being arises as an absurdity, from which one wants to escape. Being is not the home that है $\rho \omega \varsigma$ seeks.

If being-in-the-world is intrinsically meaningful and if the sheer fact of existence is absurd, from where (non-spatially) does meaning arise? Does not the very sense of this question suggest that one's meaningful being-in-the-world must derive itself from something that exceeds being - even if Dasein is not indifferent to its being? To that end, let us spell out the implications of the impossibility of loving being since it will also show us the way out of being.

As we have seen, ontic self-love (or, if one prefers, love of life) is ontologically conditioned by the attunement of Angst. At the heart of the very anxiousness of the (impossible) love of being, might we catch sight of a radically non-ontological meaning: should human beings be anxious about their self-love? Notice: this is a normative question, not an existential one. Does the is-ought distinction prevent further inquiry? Specifically, given that we are operating from within an existential analytic, aren't normative questions misplaced? No. The is-ought distinction arises where meaning is found to exceed being. In the very heart of ontological difference it is shown that the meaning of the self exceeds being, which as an absolute strikes the self as absurd. Thus, the question is not misplaced: we will exceed being by placing our very own being into question!

And yet the self cannot break out of being by means of itself. Having elucidated the philosophical imperative to dislodge the self from being, Levinas was nonetheless unable to determine the means of escape in On Escape. In Totality and Infinity, he sees pleasure as a type of escape; yet, as he had already recognized, it is an escape of broken promises since, at the very moment of climactic ecstasy, the self is tossed back upon itself in shame. Why is Dasein unable to transcend being on its own? It is hard to overemphasize the structure of Jemeinigkeit, which is inextricably bound up with ontological difference. As Heidegger tells us in his Introduction to Metaphysics, "Dasein means: care of the Being of beings as such that is ecstatically disclosed in care, not only of human Being. Dasein is 'in each case mine'; this means neither that it is posited by me nor that it is confined to an isolated ego. Dasein is itself by virtue of its essential relation to Being in general." 91 To be sure, Dasein cannot posit its own fact of existence of its own volition. Yet Jemeinigkeit implies that beings are like atomistic nodes through which the very event of being takes place. It is no wonder then that Heidegger's thought vacillates between ontological monism and ontico-ontological violence. Self-identical beings, which persist in their very being, are made possible by the transcendental unum, the primordial identity of Being itself.

Perhaps, we may escape the nausea of existence by circumscribing the atomism of Dasein by means of a transcendent universal, such as justice. Levinas asks: does not peace, which is effected by reason, lead to the otherwise than being? Levinas responds in the negative. "This rational peace, a patience and length of time, is calculation, mediation and politics. The struggle of each against all becomes

${ }^{91}$ Martin Heidegger, Introduction to Metaphysics, Gregory Fried and Richard Polt trans. (Yale University Press, 2000), p. 31. 
exchange and commerce."92 Reason is the reciprocal delimitation and assembly of beings; natural justice (peace) is the restoration of right relations amongst beings in the system of referrals-the polis. Yet, riveted to being, peace is unstable; the conatus essendi always threatens to topple the system-political or otherwise.

In order to transcend being, we must untie the knot that binds Dasein and Jemeinigkeit. How so? As we have already shown, Heidegger's thought plays itself out as modern version of the drama between Heraclitus (contradiction) and Parmenides (monism). And yet their underlying unity consists in the following: "being and intentionality are coextensive." Here, let us see if we catch sight of another possibility: is there an intentional sense that might de-neutralize the stranglehold of ontology and thereby liberate the self from being? Against Jemeinigkeit, Levinas proposes ethical alterity. This is our formal indication; let us follow it.

\section{§9: Levinas: metaphysical desire and the Other}

Despite phenomenology's pretentions towards absolute science, Levinas contends that the doctrine of intentionality is essentially incapable of manifesting the other - the other in an eminent sense. For common sense, otherness is seemingly manifest in the perceivable distinctions amongst objects, and, more fundamentally, in the distance between the cognitive subject and knowable objects. Yet, despite this, the subject's distinguishing power ultimately serves the subject's own synthetic activity. Everything is assembled by consciousness as a term in the system of intelligible relations, which Levinas calls the "totality." This unity of sense, which is the correlate of absolute consciousness, Husserl called "the world." 93 Totality, for Levinas, is the definitive trait of traditional philosophy. Here Levinas launches his critique: manifested against the backdrop of the intentional horizon and comprehended by the understanding, the phenomenon surrenders its alterity. Phenomena are not differentiated from consciousness but are derivative upon it and therefore assimilated to it. In other words, otherness is mere noematic content. Because the truth of the world is resultant upon the activity of intentional consciousness, contemplation is simultaneously the reduction of difference to the same. Thus, philosophy is essentially egology. ${ }^{94}$ In order to relate to the other, we must go beyond the Husserlian doctrine of intentionality.

"Knowledge in the absolute sense of the term, the pure experience of the other being, would have to maintain the other being $\kappa \alpha \theta$ ' $\alpha$ vitó." ${ }^{\prime 95}$ Levinas contends that, in order to maintain the integrity of this absolute experience, we must recover

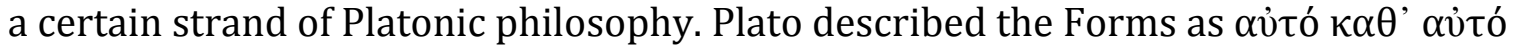
beings - beings that are what they are by reason of themselves. Now, in the Symposium, Socrates avers that $\tilde{\varepsilon} \rho \omega \varsigma$ is the desire to contemplate the Form of the Good and the Form of the Beautiful. Yet, while है $\rho \omega \varsigma$ seems to be a leading candidate for recovering this experience, it is not perfectly clear from Plato's works how these

92 Levinas, Otherwise than Being, op. cit., p. 4.

${ }_{93}$ Husserl, Ideas, op. cit., p. 106 and 143.

94 Levinas, Totality and Infinity, op. cit., p. 44.

95 Levinas, Totality and Infinity, op. cit., p. 64-65. 
$\kappa \alpha \theta^{\prime} \alpha$ vंtó beings would be disclosed to the philosophical visionary. Perhaps, Plato would have benefited from a phenomenological toolbox. Nevertheless, in elucidating this experience, Levinas rejects the intellectualist emphasis on the contemplative disclosure of reality as well as the erotic desire for self-satisfaction. By contrast, from the perspective of Plato's Good beyond being, Levinas elucidates the phenomenon of desire in connection with this pure experience of the other. And, as

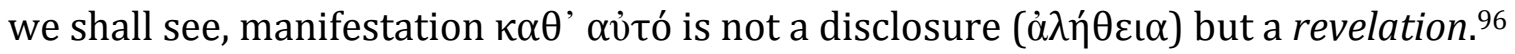

Using phenomenological analysis, Levinas distinguishes desire from need by taking, as his leading clue, Socrates' mythological suggestion that ${ }^{\prime} \rho \omega \varsigma$ is born of

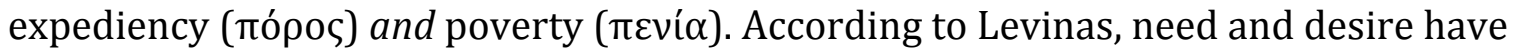
become conceptually conflated; Aristophanes is no exception. Need seems to imply a certain deficiency in the one who is lacking. Aristophanes tells his friends: the self depends on another for its own completion, albeit to the degree that the self wants to possess the other and, in some sense, become identical with the other. Desirous of intimate union, true lovers will seek the craftsmanship and welding powers of Hephaestus. Here, Levinas launches his paradoxical yet prophetic critique. Despite the appearance of a thoroughgoing dependency, the ego remains independent and self-sufficient throughout its endeavors, erotic or not. "The myth Aristophanes tells in Plato's Symposium, in which love reunites the two halves of one sole being, interprets the adventure as a return to self." 97 Levinas clarifies the concept of need by way of the phenomenon of enjoyment. That the satisfaction of one's needs generates happiness signifies

the existence at home with itself of an autochthonous I... The selfsufficiency of enjoying measures the egoism or the ipseity of the Ego and the same. Enjoyment is a withdrawal into oneself, an involution. What is termed an affective state does not have the dull monotony of a state, but is a vibrant exultation in which dawns the self. ${ }^{98}$

The phenomenality of the affective phenomenon of enjoyment is the ipseity of the ego. One needs only to recall that Dasein antecedently contextualizes its own ventures of being-in-the-world. As such, Levinas rejects - on phenomenological grounds - Aristophanes' thesis concerning $\tilde{\varepsilon} \rho \omega \varsigma$ : the phenomenon of need is not revelatory of "the other" that would complete me. To the contrary: one's needs are in view of the plenitude of the self, which, through labor, assimilate others to the

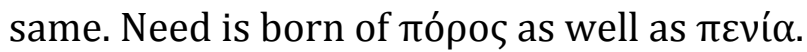

And yet we may reverse the emphasis: desire, by contrast to need, indicates

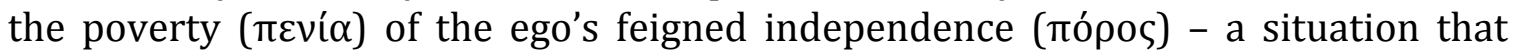
simultaneously constitutes the very positivity of the ego's relationship with another. Ipseity, as self-sufficient being-in-the-world, does not lead to genuine transcendence for Levinas. To the contrary, the conatus leads to self-destruction such that, while anchored to one's project of being, ipseity is ultimately self-alienation. Metaphysical

96 Levinas, Totality and Infinity, op. cit., p. 65.

97 Levinas, Totality and Infinity, op. cit., p. 254, my emphasis.

${ }^{98}$ Levinas, Totality and Infinity, op. cit., p. 115 and 118. 
desire loosens the stranglehold of ontology. Levinas asks his interlocutors: "Has not Plato, rejecting the myth of the androgynous being presented by Aristophanes, caught sight of the non-nostalgic character of Desire and of philosophy, implying autochthonous existence and not exile-desire as erosion of the absoluteness of being by the presence of the Desirable, which is consequently a revealed presence, opening Desire in a being that in separation experiences itself as autonomous?"99 Desire is not nostalgic for protological completion; ipseity is insufficient for desire. To the contrary: desire approaches the other, who exists forevermore beyond the enjoyable exertions and happy labors of the active ego. Deisre aims beyond every relation that the ego might seek to establish to itself. Furthermore, desire is an insatiable drive towards exteriority not only because of one's unbearable finitude but also because of the superabundance of the other. "Desire does not coincide with an unsatisfied need; it is situated beyond satisfaction and nonsatisfaction." 100 The conatus of being therefore loses its absolute character because desire aims beyond that which completes; as such, desire accomplishes the relation with the other.

If the phenomenality of the phenomena of need and enjoyment is the ipseity of the ego, then the phenomenality of desire implies the absolute separation of autonomous beings. But, how is this metaphysical situation revealed and how is desire awakened? By definition, absolute alterity defies description; therefore, "the other" is resistant to traditional phenomenological techniques. Recognizing this, Levinas examines the "traces" of the other, viz. the sites of impact upon the intentional ego. The other (exteriority) breaks into the autochthonous and selfsufficient ego (interiority). The other therefore is not disclosed by intentional consciousness but is revealed of its own accord. Levinas finds traces of the other in enigmatic phenomena such as insomnia, the face, interruption, trauma, astonishment, vulnerability, exposure and being torn from one's self. The shock that is experienced in the face of the other (indirectly) "reveals" the situation of metaphysical separation. Yet the most basic revelation consists in language and expression.

[In the vocative relation] a relation in which the terms absolve themselves from the relation, remain absolute within the relation, ... manifestation $\kappa \alpha \theta^{\prime} \alpha \hat{\tau} \tau o ́$ consists in a being telling itself to us independently of every position we would have taken in its regard, expressing itself... The essential of language: the coinciding of the revealer and the revealed in the face, which is accomplished in being situated in height with respect to us-in teaching... Discourse is thus the experience of something absolutely foreign, a pure "knowledge" or "experience," a traumatism of astonishment.101

Discourse communicates that which is strictly unforeseeable and unsynthesizable because it comes entirely from the other. The "face-to-face" relation is therefore

${ }^{99}$ Levinas, Totality and Infinity, op. cit., p. 63.

${ }^{100}$ Levinas, Totality and Infinity, op. cit., p. 179.

${ }^{101}$ Levinas, Totality and Infinity, op. cit., p. 64-74. 
primarily "counter-intentional," which is to say that intentionality proceeds from the other towards the autochthonous ego. Consequently, because this revelation leads to an essential breakup of consciousness, "the other" can't be formulated into noematic content by intentional ego. Yet feeling the gaze of the other, who remains strictly invisible and disengaged from every visible form, I am intimately aware of the other's presence.

We must be clear that the face-to-face encounter does not manifest neutral, or transcendentally reduced, information-namely, metaphysical separation. Levinas tells us: "I have access to the alterity of the other from the society that I maintain with him, and not by quitting this relation in order to reflect on its terms." 102 That is, the experience of the other does not give way to disinterested contemplation but evokes ethical responsibility. Why does revelation simpliciter not provide access to the alterity of the other? Answer: discourse with the other renders the ego responsible for the other. If the other cannot be assimilated to the same, then one's "intentional response" to $\kappa \alpha \theta^{\prime}$ ' $\alpha$ vó revelation precludes any return to the self. Metaphysical desire accomplishes this inversion of intentionality. If not foritself, the subject must be for-another. Facing the other, the ego can only respond with infinite desire - infinite because the other cannot be circumscribed by the ego's cognitive powers or existential needs. Thus, the breakup of consciousness is neither meaningless nor ultimate because exposure to the other remains ethically meaningful. While entirely postmodern in his criticisms of reason and subjectivity, Levinas remains committed to an entirely premodern concern for the meaning of goodness. The relation with the other is not a simple relationship of difference; rather, it is a relation that is essentially non-indifferent. Transcendence is no longer situated in an epistemological or gnoseological frame; nor does it indicate the leap to authentic existence under the reign of ontological difference. To the contrary: genuine transcendence is meaningful only as ethical responsibility-infinitely directed towards and for the other.

Concretely: the infinite desire must be donative (of being). Prior to the war of all against all, where each is striving to be, the self must peacefully give the world unto the other; that is, the ego renounces its being-in-the-world for the sake of the other. Desire is thus concretely played out as the inverse of Sorge.

The relationship with the Other is not produced outside of the world, but puts in question the world possessed. The relationship with the Other, transcendence, consists in speaking the world to the Other... The hic et nunc itself issues from possession, in which the thing is grasped, and language, which designates it to the other, is a primordial dispossession, a first donation. The generality of the word institutes a common world. The ethical event at the basis of generalization is the underlying intention of language. ${ }^{103}$

102 Levinas, Totality and Infinity, op. cit., p. 121, my emphasis.

103 Levinas, Totality and Infinity, op. cit., p. 173. 
The world no longer provides the context for Dasein's anguished being-in-the-world. To the contrary: the world's very signification is based upon that which has no context ( $\kappa \theta^{\prime} \alpha$ 'o $\tau$ ó other). The world is given to the other (in justice) and the social relation is characterized as an infinite approach towards the other (in dialogue). "We call justice this face to face approach, in conversation."104 The world can be meaningful for human beings only within this context of sociality. Ethical responsibility thus establishes an "eschatology of messianic peace," a confraternal relationship of human individuals that is announced from beyond the totality and therefore prior to the ontology of war wherein beings simply strive to be. Desire is finally seen to be infinite and donative as opposed to finite and nihilating. That is to say, desire is an inordinate "intentionality," which exceeds the dynamic selfcompletion of being by giving the world unto the other. Ethics thereby concretizes one's relation with genuine alterity, the Other.

This meta-ethics does not resemble traditional theories. It is not the cultivation of virtue as in (Thomistic) Aristotelianism. Nor is it rational selflegislation as in the deontology of Kant. Nor is it the calculation of happiness as in utilitarianism. Nor does it imply that society is founded upon the contemplation of truth $(\theta \varepsilon \omega \rho i \alpha)$ as it is for the intellectualist. Levinas contends that all of these theories have been characteristically unethical - to the extent that they are egocentric. The other is necessarily resistant to the ego's exertions thereby challenging traditional modes of rationality. "The notion of the face ... brings us to a notion of meaning prior to my Sinngebung and thus independent of my initiative and power." ${ }^{105}$ Concretely, the face of the other signals the deep ethical structure of reality. The other says "Here I am; do not kill me." What's more, the other - the orphan, the widow and the stranger - grips me to the very depths of my being. The other is my master - the one whom I am called to serve with the utmost humility. Or, stated with maximal extremity in Otherwise than Being, the infinite difference that separates myself from another is characterized by my absolute non-indifference to the point of ethical obsession. ${ }^{106}$ Ethics is therefore meaningful not as personal flourishing but only as infinite responsibility for the other, who nonetheless remains invisible. As long as philosophy remains unaware of this ethical "optics," genuine alterity will remain occluded.

We are now in a position to understand Levinas' famous claim that "ethics is first philosophy." The philosophical task does not consist in the pursuit of truth or the exhibition of being - a tradition that spans from Aristotle to Husserl and Heidegger. However, just as Plato sought "the structure of the one-for-the-other inscribed in human fraternity," 107 Levinas determines the philosophical task as the pursuit of the meaning of the Good "beyond being." Desire is neither satisfied in cognitive intuition nor fulfilled in practical flourishing; rather, exceeding the understanding that measures beings, desire is an inordinate transcendence that concretely maintains a social relation with the other. Ontology is no longer first: it is

104 Levinas, Totality and Infinity, op. cit., p. 71.

105 Levinas, Totality and Infinity, op. cit., p. 51.

106 Levinas, Otherwise than Being, op. cit., p. 85.

107 Levinas, Otherwise than Being, op. cit., p. 166. 
interrupted from within and de-neutralized by ethical responsibility. The Good founds and justifies being. Thus, the very meaning of human life, which is announced from beyond ontological difference, "is derived from infinite responsibility, from the profound stewardship which constitutes the subjectivity of the subject: a responsibility which precludes any return to oneself, because it is wholly directed towards the Other." 108

\section{\$10: Marion: the transparent gift of haecceitas, or love opening onto the Other}

The situation seems bleak for the phenomenology of love. As we ventured from the outset, love is neither irrational nor merely affective but furnishes knowledge of the other, an utterly unique but genuine experience of pure alterity that exceeds ordinary knowledge. Yet we have arrived at no such experience. On the one hand, Husserl's intersubjective reduction and Heidegger's existential analytic constrained love within immanence, caught in the aporia of solipsism. On the other hand, Levinas' theory of ethical alterity saw love as the equivocal phenomenon par excellence. "By an essential aspect love, which as transcendence goes unto the Other, throws us back this side of immanence itself: it designates a movement by which a being seeks that to which it was bound before even having taken the initiative of the search and despite the exteriority in which it finds it."109 Despite his Platonism, Levinas rejected the possibility of erotic transcendence since, for him, love seeks union with the other only on the grounds of some egocentric need. Only infinite responsibility "reaches" the other in a social relation "without relation." That is, the sense of the other must be purged of every egoic reduction, including the very idea of "experience." By contrast, Marion tells us, love's very solipsism results in autistic asociality.

And yet Marion believes that the phenomenology of love is not hopeless. Albeit differing in details, Marion accepts the critique of intentionality proffered by Levinas, for whom the other is precisely that which cannot be constituted by intentionality. Let us bear out this basic fact: the other is, by definition, invisible. As an intentional subject, the other constitutes (and thus precedes) the objective visible world. Thus, when face-to-face with the other, "in the very midst of the visible, there is nothing to see, except an invisible and untargetable (invisable) void." 110 And yet the ego insists on gazing at the other's face. Why? As Levinas had already argued, the other's gaze affects the ego in counter-intentional fashion; that is, "if there is nothing to see there, it is from there that the other takes the initiative to see (me)."111 I am gripped by that initiative whereby the other gaze challenges my right to constitute the world. Am I thereby rendered a mere object? Let us be clear: the situation of crossed gazes (from the one to the other and vice versa) does not necessarily result in reciprocal objectification, even if it remains a possible comportment for each ego. That is to say, I am not merely objectified before the

${ }^{108}$ Emmanuel Levinas, Proper Names, Michael B. Smith trans. (Stanford, California:

Stanford University Press, 1996), p. 74.

${ }^{109}$ Levinas, Totality and Infinity, op. cit., p. 254.

110 Marion, Prolegomena to Charity, op. cit., p. 81.

111 Marion, Prolegomena to Charity, op. cit., p. 82. 
other, even as I am able to objectify him or her. To the contrary: for Marion (and Levinas), the ego experiences itself as accused. Marion is referring to the "accusative case," which etymologically and grammatically indicates the teleology of motion. As such, the other "appears" as an uncontrollable and anterior "cause towards which" the ego is provoked to move. And, as we know from Levinas, this concretely means that, against the stream of consciousness (intentionality), the other is lodged into (sub) consciousness as a moral "injunction." Unlike Levinas, however, Marion sees this as the initial intimations of a phenomenology of love.

Whence comes what we will from now on consider the phenomenological determination of love: two definitively invisible gazes (intentionality and the injunction) cross one another, and thus together trace a cross that is invisible to every gaze other than theirs alone. ${ }^{112}$

Note well: Marion is more confident in the experience of the weight of another gaze (in the form of the injunction) than Levinas, for whom the structure of human sociality is inferred from the cracks in existence that are traced by the other. Nevertheless, in the crossing of the gazes (intentionality and the injunction, which is precisely the phenomenality of love), there is a genuine lived experience, even if it is not an experience of visibility. But how is this love, as distinguished from ethical responsibility?

Let us focus on two interrelated problems that arise here for it will answer our question. (1) Why is the crossing of the gazes invisible to every gaze other than theirs alone? Isn't the injunction merely to be inferred, not experienced? In other words, how do the gazes cross in a lived experience, if not visibly? (2) How does love reach an absolute individuality? Doesn't the injunction arise in consciousness as a universal law, that is, for any and every other? Against Levinas, for whom ethical responsibility is indifferent to particular others, Marion points out that "the injunction does not lead to loving this other, if only the universality of the law pronounces it; rather, it leads to the law itself, while neutralizing the other in particular."113 While not abrogating the injunction, love is supposed to pass through yet beyond universal responsibility in order to reach the other qua individual.

Love requires nothing less than haecceitas, ... [which] passes beyond beingness in general, but also beyond that which, in the injunction and responsibility, falls under the universal, and thus the Neuter... Haecceitas decides for an absolute separation from every similitude, to the point of provoking the holiness of the other. The other alone singles himself out. ${ }^{114}$

\footnotetext{
112 Marion, Prolegomena to Charity, op. cit., p. 87. To be clear, the "injunction" is Marion's term.

113 Marion, Prolegomena to Charity, op. cit., p. 93.

114 Marion, Prolegomena to Charity, op. cit., p. 95-96.
} 
Far from resolving the problem, this only enhances love's difficulties. In classical epistemology, for which the knowledge of particulars proceeds by way of universal categories, singularities are, by definition, unknowable. Thus, as an utterly singular unicity, the other is unknowable in a twofold sense: qua subject and qua individual. Again, let us ask: is the other in particular open to experience, or does this merely intensify and therefore conclude the aporia of alterity? To the contrary: as we shall see, the other's individuality is precisely that which reinforces the experiential quality of the crossed gazes and thereby constitutes the unique (epistemic) character of the phenomenon of love (which lives beyond yet through ethical responsibility).

How does love give access to an irreplaceable individuality, not exchangeable for any other? But first, an objection: does not the idea of haecceitas repeat the very "mineness" of Dasein in a signification that opens onto the ontico-ontological violence of being's interest as it unfolds through atomistic nodes, or beings? And, if haecceitas implies that the other is simply another monadic ego, then wouldn't the other be accessible by way of analogical appresentation (Husserl) or genuine Fürsorge (Heidegger) thereby rendering love either redundant or obsolete? To the contrary: in the crossing of the gazes, each ego renounces its intentionality only to weigh into their own gaze as an absolute particularity (haecceitas).

The other requires his haecceitas not because he imposes it on me as his rule, but because it is necessary for me that it be imposed in order that the injunction allow me to experience his gaze as such. Inversely, I can and even must renounce my own, my proprietorship of egoity for the sake of exposing myself to alterity. ${ }^{115}$

That is, haecceitas is not a source of violent imposition; it is the condition of possibility for the experience of alterity. The other does not weigh into his gaze as a world-constituting ego; rather, the other renounces his own worldly proprietorship so as to leap into love as an irreplaceable singularity, irreducible to the universality of intentionality and being-in-the-world. Let us be clear: intentionality is no one's because of its transcendental quality while Dasein is no one's because of the anonymity of being's interest. Nevertheless, while the other renounces his egoity, I must withdraw my intentionality in order to create the space for the other to give his or her own haecceitas, in utter freedom. Conversely, while I withdraw my own intentionality, I leap into love as an irreplaceable singularity; that is, in challenging my constitutive rights over the world, the other's gaze qua injunction urges me to step forth in all of my individuality. Thus, haecceitas is the very reality of individuality, irreducible to intentionality consciousness, freely given and freely received. Thus, we may characterize Marion's theory of "lived experience crossed"

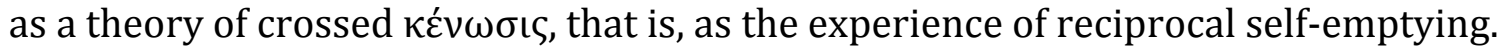

Self-emptying in two senses: (1) renunciation of intentionality in order to grant the other's freedom of self-expression, (2) and the mad ecstasy of exposing oneself to the other as an irreplaceable haecceitas. "The injunction that would finally

115 Marion, Prolegomena to Charity, op. cit., p. 97. 
put into play the other as such would, thus, also accomplish the transgression of intentionality by love."116 Why? On the one hand, intentionality - ineluctably leading to transcendental solipsism - crowds out other gazes; yet, in freedom (!), each gaze may renounce its intentionality in order to create the space for genuine haecceitas to shine forth. As such, we have discovered two central determinations of love. (1) By way of love, we have discovered, for the first time, genuine $\kappa \alpha \theta$ ' $\alpha$ v่tó experience of the other. (2) In a paradoxical way, renouncing the ego's intentional powers enables me to attain, for the first time, my status as a unique Self, irreducible to the status of being a mere instance of the more universal categories of Dasein or

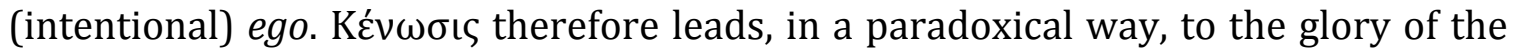
Self.

But, Marion concludes, "to render oneself other, to surrender this gaze to the gaze of the other who crosses me, requires faith."117

\section{\$11: The leap of faith, or the transvaluation in love}

The obvious theological resonance of this conclusion will no doubt disturb the philosopher; yet we can view faith under its universal aspect as the "cause" of any existential decision. Marion invokes faith in order to introduce another dimension to the phenomenology of love, namely, the will. Appropriately, this invocation of faith concludes his essay, "The Intentionality of Love," because "the leap of faith" is the starting point of love, or rather it is the acceptance of the gift of the other's presence, which is otherwise obscured by the attempt to comprehend it. Love neither resides in the domain of reason nor does it constitute a mere transcendental structure of human experience. To love is to will to love. That is, love must be embraced with the utmost freedom, or it must be rejected as a scandal to reason: this is the choice.

For the other to appear, the ego must allow it to appear. As we saw, in the case of Husserl, the analogous appresentation of the other "in person" when perceiving an animate organism enables the ego to transfer the sense of "alter ego" to said organism. Yet the transfer is not necessary; rather, the passive synthesis of association can only motivate it. For the sense "alter ego" to appear, the ego must choose to transfer the sense. Husserl seemed unaware of this fact. The same can be said of Mitdasein. As we know, either the other can be delivered to its own authentic care (Fürsorge), or its care can be "taken over." In the latter case, the other Dasein becomes none other than a dependent, innerworldly being. At its worst, the other is rendered Vorhandenheit, to be contemplated or even manipulated. Nevertheless, the other's status is dependent upon a choice. One needs only consider Heidegger's political affiliations in order to see that the existential structure of Mitdasein does not necessarily reveal the other qua other (in all of their unique individuality), except by way of a choice that affirms their authentic being-in-the-world. Thus, let us confirm that, just because we understand that human beings characteristically exhibit certain behaviors such as being able to operate in the world (Heidegger) or being able to perceive by way of affective sensibility (Husserl), does not thereby

116 Marion, Prolegomena to Charity, op. cit., p. 98.

117 Marion, Prolegomena to Charity, op. cit., p. 101. 
ineluctably lead to the affirmation of humanity in a particular individual. The will is thus a matter of phenomenology. We may also mention that humans easily numb themselves to the shock of alterity, in their everyday experiences, by merely treating others in their functional capacity (as factory worker, firefighter, politician, etc.). Thus, we may conclude that the other is dependent on my good will, albeit in a distinctive sense.

Marion criticizes Kant on this score. "The phenomenality of the other does not precede my (good) will with regard to him, but instead is its result," Marion tells us. "Kant of course presupposes what is most aporetic (that I admit another person, another myself) and passes over it in silence, in order to establish at length what is most evident (the universality and reciprocity of the 'golden rule')."118 It is this radical choice that enables the other to appear. Reciprocal objectification is not the only possibility when face-to-face with another; each gaze can either accept or refuse the other's counter-gaze. Having affirmed its importance, how precisely does the will enable the other to appear? Answer: by choosing to renounce its intentionality, the ego "opens the space where the gaze of the other can shine forth. The other appears only if I gratuitously give him the space in which to appear." ${ }^{119}$ By relinquishing my mastery, the other is liberated to freely give himself or herself (qua haecceitas) to me. Dasein must withdraw itself, recoil its conatus, in order to clear the space for that-which-is-not (namely, the other's gaze) to be; that is, I must give my world unto the Other in order to sustain their unique individuality.

And yet this renunciation is not simply a negative condition, a simple

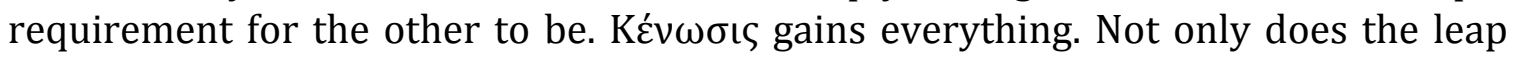
enable the other to shine forth but also the leap decides me, singularizes me, because faith is willed on the basis of itself. Love's faith, or faith's love, is the ownmost reality of the self, the "heart." And, as we have also seen, if the other responds with love as well, they renounce their intentionality in order to make room for my haecceitas. What's more, the other gives itself as a superabundant gift in the twofold sense that the other not only creates the space for my gaze to shine forth but also gives himself or herself in their very haecceitas, a reality no less real

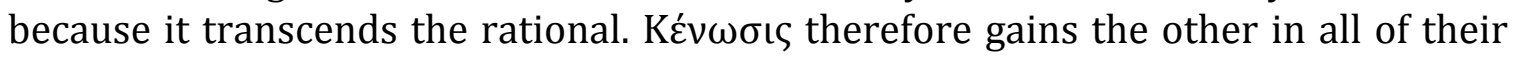
glory. Thus, love is not capricious degradation of reason in favor of the irrational; rather, the leap of faith leads to the will's "transvaluation in love," as Marion tells us in a polemic against Nietzsche. Having no control over the anterior freedom of the other's invisible and superabundant gift, the will chooses "to abandon itself to the gift, instead of assuring itself of a possession." ${ }^{120}$ But, this means that, because the gift transcends the comprehensive vision of the rational understanding, the gaze must work to "see" the gift. There is too much to be rendered visible and reason will always treat it as a sub-rational obscurity. After the leap, which is already an impossible task (in virtue of the other's invisibility), the gaze must be trained to acknowledge the other's reality - a focal adjustment that is nonetheless made possible by the anterior gift of the other's presence. "Thus only the conversion of the

118 Marion, Prolegomena to Charity, op. cit., p. 163-4.

119 Marion, Prolegomena to Charity, op. cit., p. 166.

120 Marion, Prolegomena to Charity, op. cit., p. 64. 
gaze can render the eye apt to recognize the blinding evidence of love in what bedazzles it," an epiphany of the other. ${ }^{121}$

Here, we have finally caught sight of love as the unique experience of alterity, which enables the other and the self to appear as irreplaceable haecceities that are bound together in a social relationship that transcends worldly modes of being (and truth).

\section{§12: Inter-missio: erotic transcendence or erotic immanence?}

Let us take stock. For Plato, the Good and the Beautiful are decisively situated in है $\rho \omega \varsigma$. That is to say, they are first revealed as desirable. Admittedly, "̌ $\rho \omega \varsigma$ has a teleological structure: it is ordered towards contemplative adoration of the Forms. And philosophy is, in some sense, soteriologically defined: seeking liberation from the vicissitudes of change and the limitations of imperfection, erotic desire wants to be satiated by the transcendent, immutable Forms. Yet, according to the SoctraticPlatonic determination of the philosopher, wisdom is an unattainable transcendent that can only be asymptotically approached by way of erotic ecstasy and passionate questioning; wisdom is thus a regulative ideal that governs the philosopher's way of life en route in the world. For the intellectualist on the other hand - a category that includes, on some interpretations, Aristotle, Kant and Husserl - है $\rho \omega \varsigma$ gives way to the disinterested, comprehensive vision of reality $(\theta \varepsilon \omega \rho i ́ \alpha)$ such that desire is no longer characteristic of the ego as such. Desire becomes simply a modality of intentional consciousness, which reason controls in its theoretical and practical endeavors. That is to say, desire is subordinated to the theoretical teleology that is definitive of the ego; or, at its extreme, desire is renounced in order to liberate the penetrating vision of the self-sufficient, non-participant onlooker.

Heidegger represented a shift - simultaneously away from modern abstract intellectualism and away from ancient cosmic transcendence. No longer the site of the Good and the Beautiful, है $\rho \omega \varsigma$ drops out in favor of a radicalized version of Aristophanes' "erotic need." Intentionality, for Heidegger, is essentially nostalgic for ontological self-completion: to-be-in-the-world is to strive to be-conatus essendi. Aristophanes only half-grasped the true situation himself: anthropic self-fulfillment is derivative upon ontological dénouement. Heidegger's existential determination of Dasein as Sorge therefore comprehends the ontological situation more profoundly than Aristophanes' ě $\rho \omega \varsigma$. That is, the practical concern for one's being is Dasein's fundamental way of being-in-the-world - without reference to ontic difference (eidetic or individual). Dasein's authentic care is originary transcendence beyond innerworldly being, a transcendence that nonetheless makes the transcendence of innerworldly being possible. What's more, this shift is something of a completion of philosophy's aspirations: coextensive with phenomenality, intentionality opens up the being of beings while remaining fundamentally porous to it. Thus, the understanding of being has become an active, dynamic existential engagement with being, not merely a disinterested and static "vision." It seems that, in the wake of Heidegger, the philosopher's destiny is to plumb the depths of being.

${ }^{121}$ Marion, Prolegomena to Charity, op. cit., p. 66. 
And yet the other remains something of an enigma within the field of being. In hope, the philosopher might be elevated beyond it. Instead of restoring है $\rho \omega \varsigma$ to its privileged relationship with $\kappa \alpha \theta$ ' $\alpha$ òtó being, Levinas leaves ह̌ $\rho \omega \varsigma$ in Aristophanes' hands and sets his prophetic crosshairs - on Heidegger. Not simply returning to the self over and against being, Levinas tells us that है $\rho \omega \varsigma$ is the equivocal phenomenon par excellence. That is, है $\rho \omega \varsigma$ simultaneously presupposes need and desire such that "love remains a relation with the Other that turns into need, and this need still presupposes the total, transcendent exteriority of the other, of the beloved." ${ }^{122}$ If only the philosopher could catch a glimpse of the desire that is antecedent to and purified of the erotic impulse towards possession of the other. Tracing the cracks within being, Levinas liberates desire from erotic self-fulfillment by way of ethical alterity. Thus, in contradistinction to the Greek notion of cosmic transcendence by way of है $\rho \omega \varsigma$, Levinas discovers that genuine transcendence (beyond being) consists in the social transcendence of "metaphysical desire" - the ethical relation of infinite responsibility towards the other that precedes worldly being.

Following Levinas, Marion privileges concrete, social transcendence over abstract, cosmic transcendence; yet, unlike Levinas, Marion is more confident in the experiential quality of love. Marion determines the phenomenon of love as the reciprocal self-emptying of the crossed gazes in the face-to-face relation. As crossed $\kappa \varepsilon ́ v \omega \sigma \iota \varsigma$, love is the transgression and renunciation of intentionality as well as the mad ecstasy of haecceitas. Thus, unlike Levinas, the self and the other genuinely appear in the $\kappa \alpha \theta^{\prime} \alpha \dot{\tau} \tau$ ó experience of love thereby giving meaning to worldly existence. The social relation of love is the foundation of the world.

Have we thereby restored the erotic intelligibility of the world? Yes, only when we consider love as a way of life, not as cosmic transcendence. Since the ego can only hope to approach the other, the will and the affections are essential characteristics of love. In moving beyond the theoretical attitude, which hopes to comprehend the other, the will and the affections cannot be reduced to the private sphere of ownness but are universal (phenomenological) structures for the experience of the other. That is, only as an affective and volitional act is love able to open knowledge of the other. We need not repeat that this act is fundamentally kenotic; nevertheless, it is clear that, because the other exceeds the ego's synthesizing powers, the other must be approached actively and dynamically as opposed to disinterestedly and statically. Moreover, love does not provide knowledge of the other as a unique variant of the this-worldly, theoretical consciousness; rather, love concerns that which transcends the knowledge of mere objects. Thus, the will must choose to convert its gaze vis-à-vis the other in an evercontinuing process of existential engagement. This brings Marion quite close to the Greek notion of the erotic way of life. For Plato, when the soul knows that it lacks perfect, transcendent knowledge, the philosopher can only desire to move ever closer towards it. Hence, whereas only the gods and the sage possessed true knowledge, the intelligible world was accessible to the philosopher only by way of the soul's erotic dynamism. Having recovered the importance of the will and affection in the appearance of the other such, Marion has brought us closer to this

${ }^{122}$ Levinas, Totality and Infinity, op. cit., p. 254. 
dynamically construed erotic intelligibility of the world. Like Plato's है $\rho \omega \varsigma$, love arises as a unique way of life, a training of the gaze in order to see the gift of the presence of the transcendent other. Love treats neither reason nor worldly modes of beings as ultimate; it transcends worldly modes of knowledge, by slackening the intentional rapport with the world, in order to "see" the invisible gift that precedes and gives meaning to the world. Unlike the Greeks however, the phenomenology of love has uncovered love as social transcendence, not cosmic transcendence. This is the fundamental difference. Nevertheless, in union with the Greeks, love has been discovered as the preeminent human experience, which gives concrete meaning to human existence.

At this juncture, let us follow an entirely different path in tracing our phenomenology of love. I have unequivocally favored "transcendence" - whether the epistemic transcendence of Husserl, the ontological transcendence of Heidegger, the ethical transcendence of Levinas or the erotic transcendence of Marion. By contrast, Henry has developed a powerful theory of what I might call "erotic immanence." But doesn't immanence fall prey to Levinas' critique? Yes, to the extent that immanence is formulated in egocentric terms; yet, for Henry, erotic immanence is neither egocentric nor transcendent. To be specific, Henry's notion of Leib is immune to Levinas' criticisms because Henry equally rejects the primacy of worldly modes of being and knowledge, as determined by Heidegger and Husserl. In contradistinction to all of the aforementioned thinkers, Henry is confident in the revelatory power of immanent life, especially as it reveals ultimate reality. Perhaps then, in light of Henry's work, we have been misplaced to pursue the erotic intelligibility of the world by way of transcendence. This is important not only because Henry represents a great challenge to our analysis of erotic transcendence but also because Henry arrived at erotic immanence partly by way of his phenomenology of Christianity. Thus, since we hope to compare the phenomenology of love with the Christian account of $\alpha \gamma \alpha$ ' $\pi \eta$, we must analyze Henry's challenge to transcendence. Thus, we turn to Michel Henry and his powerful phenomenology of Life.

\section{§13: Henry: phenomenality and essential truth}

For Henry, the object of phenomenology in the philosophical sense is phenomenality or, "more precisely, the original mode by which this pure phenomenality becomes a phenomenon." 123 While we will postpone our inquiry into the latter precision, let us consider why phenomenality is the proper object of phenomenology - philosophically considered. Following his predecessors, Henry distinguishes the philosophical sense from the naïve, pre-critical sense. According to the naïveté of the natural attitude, phenomenology is defined simply as the faithful description of any given phenomenon. "To the things themselves!" Because all phenomena must be liberated from external interpretations, this project has entailed a rejection of tradition. While certainly constituting something of a revolution in the history of thought, this project so-conceived is not as radical as one

${ }^{123}$ Michel Henry, Material Phenomenology, Scott Davidson trans. (Fordham University Press, 2008), p. 16. 
might think. Only from a critical, philosophical perspective might we discover the root of all phenomena. Phenomenality is the mode of givenness of phenomena. It is precisely that which enables a phenomenon to appear to consciousness. While the natural and human sciences determine the essence, or the "what," of the objects appropriate to their discipline, phenomenology determines the conditions for the possibility of any appearance in the first place. Thus, phenomenology's proper object is appearing as such, or the "how" of any given phenomenon.

If phenomenality is a phenomenon's appearing considered in itself and as such, then phenomenality is the truth understood in an originary sense." According to the natural attitude, truth is seen as the intellect's conformity to reality adaequatio rei et intellectus, in its traditional Latin formula. This is accurate enough for common sense. But, for phenomenology, truth is not merely adaequatio rei et intellectus; to the contrary, "the fact of self-showing, considered in itself and as such - that is the essence of truth." 124 Accordingly, everything truly shows itself only to the extent that it shows itself according to the structures of manifestation as such. For example, a baseball is truly round because it has manifested an aspect of roundness. Consequently, ontic truths - which include both contingent and necessary truths - are dependent upon and therefore secondary to phenomenality, which is truth understood in an originary sense. As Henry tells us, ontic truth "refers back to a pure phenomenological truth that it presupposes, refers back to the pure act of self-showing, considered in itself and as such."125

What enables manifestation as such? Does consciousness - that is, thinking substance - have rights to phenomenality? It would be strange to answer in the affirmative. Should not phenomenality belong by rights to the phenomenon itself? Yet, for Husserl, consciousness is dialectically related to objects and knowledge is constituted by that relation. Heidegger retorts: phenomena disclose themselves without appeal to consciousness; phenomenality is coordinate to being. That which is gives itself. However, are there not certain enigmatic phenomena that do not give themselves according to the structures of being - such as the human face? Perhaps, phenomena give themselves before they enter the field of being as Marion argued; as such, phenomenality would have a scope wider than being. Or, perhaps, it is narrower than presupposed. Levinas limits the scope of phenomenality to secure the integrity of alterity. The invisible other is not rendered a phenomenon but can only be approached in infinite responsibility. In spite of these options, Henry interprets the situation differently than his predecessors; he displaces the concept of phenomenality while clarifying it. Phenomenality is no longer coextensive with the hetero-affective experience of mundane objects; on the contrary, phenomenality is the transcendental auto-affectivity of the ego itself. Let us elaborate.

Henry argues that traditional phenomenology has virtually occluded phenomenality - the "how" of phenomena - precisely insofar as it is codified wholly in terms appropriate to the perception of mundane objects. The truth, as we have seen, is characterized as the transcendent horizon against which phenomena manifest themselves.

124 Henry, I am the Truth, op. cit., p. 13.

125 Henry, I am the Truth, op. cit., p. 13. 
Consciousness is defined as an active transcendence that projects beyond beings the horizon on which they become visible... The "world's truth" is nothing other than this: a self-production of "outsideness" as the horizon of visibility in and through which every thing can become visible and thus become a "phenomenon" for us... Consciousness is nothing other than this relation to the object. ${ }^{126}$

Knowledge, which is pre-critically defined as adaequatio rei et intellectus, is made possible by this pure intentional relation of "subject" to "object." This assumption, which is fundamentally indifferent to that which it reveals, is taken as the universal structure of manifestation.

Henry defines this tendency, which commences with the Greeks and has been endemic to philosophy ever since, as "ontological monism." The claim is not that philosophy has tended towards a monism of substance as in Parmenides, for example. However, it is to claim that all of reality necessarily appears according to a singularly decisive modality, namely, transcendence. As we have seen for Husserl, the universal a priori of experience is intentionality and constitution. In Heidegger this is expressed as an "elevation of pure transcendence to the rank of a universal ontological category and to the condition of everything that is." ${ }^{27}$ And yet, as Henry asks, is the self given to itself according to this modality?

Henry declares that it is impossible to reach self-givenness through the exteriority of vision. Let us pose the problem in the form of a question: if we are seeking phenomenality and phenomenality is defined as intentional consciousness, then how is intentional consciousness given to itself? As early as his 1907 Göttingen Lectures, Husserl sought to address this question by investigating phenomenology's foundations. That is to say, "phenomenology returns to itself for the first time in order to understand itself in terms of its object and its means." ${ }^{128}$ Husserl's method runs as follows:

Every intellectual experience, indeed every experience whatsoever, can be made into an object of pure seeing and apprehension while it is occurring. And in this act of seeing it is an absolute givenness. It is given as an existing entity, as a "this-here." It would make no sense at all to doubt its being. ${ }^{129}$

The phenomenological reduction converts one's gaze - from objects posited naïvely as real - towards the experience itself so as to analyze its inherent structure as it is given in itself. Henry does not deny that it is senseless to doubt vision. Nor does he express concern with the act of self-foundation per se. Rather, Henry criticizes

${ }^{126}$ Henry, I am the Truth, op. cit., pp. 16-17.

127 Henry, Material Phenomenology, op. cit., p. 58.

${ }^{128}$ Henry, Material Phenomenology, op. cit., p. 43.

${ }^{129}$ Edmund Husserl, The Idea of Phenomenology, William P. Alston and George

Nakhnikian trans. (The Hague: Martinus Nijhoff Publishers, 1964), p. 24. 
Husserl's central assumption, namely, "seeing" the "seeing" itself provides an absolute foundation. Henry regards this argument as a mystification. Why would a "seeing" (cogitatio) become absolute by another "seeing" (pure gaze) - especially if that original seeing were not already an absolute given? What's more, as Henry argues in painstaking detail, the pure gaze effectively "de-realizes the cogitatio in an essential way."130 It is essentially impossible to catch sight of the cogitatio, as it is in itself, through the regard of the phenomenological gaze. In other words, I cannot somehow stand outside of myself so as to look at my own active ego as though it were an object like any other. Thus, in opposition to Husserl's methodology, Henry declares the cogitatio to be "independent from and ontologically prior to the pure gaze." 131 The self-givenness of the cogitatio is therefore not possible according to the production of transcendence that is inherent to the act of vision.

If self-givenness is impossible as transcendence, then it is only possible as immanence. Immanence signifies that self-givenness (Selbstgegebenheit), "which is to say pure phenomenality in its original phenomenalization, becomes a phenomenon in itself without leaving itself and without producing any separation."132 Unlike mundane reality, which is constituted by the transcending work of intentional consciousness, the self always already feels itself without any gap. That is to say, the self does not separate from itself and disengage from lived experience so as to know itself. "There always acts within [seeing] a power other than its own, a power in which it is auto-affected so that it feels its seeing and feels itself seeing... This auto-affection is the original phenomenality, the original givenness as a self-givenness." 133 There is no room here for transcendent disclosure in the light of worldly being. To the contrary: the self immediately feels itself and is itself the very content and the very power of self-manifestation. And, since it is always already given to itself, auto-affection is invisible and absolute. Henry defines this radically immanent, transcendental auto-affectivity of the absolute subject as Life.

Let us be clear in regards to methodology. How is a philosophy of life possible if not according to traditional methodologies? That is to say, how can we render invisible life visible? As we learned from $\$ 7$ of Heidegger's groundbreaking Being and Time, phenomenology implies an ontological as well as methodological thesis. Phenomenality is the mode of givenness of a phenomenon or, to say the same thing, the means of access to the phenomenon. Hence, for traditional phenomenology, "the object and the method of phenomenology are identical."134 Yet, for Henry, the traditional methods of phenomenology are essentially incapable of bringing transcendental life into the light. Strictly speaking, life remains invisible. The issue is therefore all the more urgent: how can we disclose invisible life? Henry answers: while life remains uncompromisingly invisible, "the primal knowledge of life is living itself. It is taken in and through living, in the phenomenological

${ }^{130}$ Henry, Material Phenomenology, op. cit., p. 48.

131 Henry, Material Phenomenology, op. cit., p. 46, my emphasis.

132 Henry, Material Phenomenology, op. cit., p. 51.

133 Henry, Material Phenomenology, op. cit., p. 81.

134 Henry, Material Phenomenology, op. cit., p. 89. 
actualization of its self-revelation in pathos." ${ }^{135}$ As long as one immanently embraces (non-intentionality) life's pathetic auto-affection, then it will be immediately revealed according to its non-ek-static modality. Precisely here, in life's absolute embrace of itself, Henry determines his theory of erotic immanence, which Henry also believes to be supported by biblical revelation. Let us explore this putative congruence of thought between Christianity and Henry's philosophy of Leib.

\section{§14: Leib and love}

Henry subtitled his first theological work, I Am The Truth (1996), "toward a philosophy of Christianity." Henry's system is not motivated by the Church Fathers for whom Christianity was "the fulfillment of the fragmented meaning of the world (logos spermatikos), which in the Word Made Flesh (Logos sarx) achieves unity and fullness and redeemed freedom."136 Absolute Life is not measured by the truth of the world. Nor does Henry take Augustine as his guide. As Augustine had argued in his epochal City of God, the true philosopher (i.e. the lover of wisdom) must be distinguished from the pagan philosophers. "If wisdom is identical with God ... then the true philosopher is the lover of God." 137 For Augustine, the true philosopher understands that the absolute incomprehensibility of the divine essence implies the following: the necessity of divine illumination and the inchoate and proleptic character of pre-eschatological $\theta \varepsilon \omega \rho i \alpha$. Apophasis impinges on theology at all points and the starting point for rational reflection on God must always remain faith. Nevertheless, while knowledge only acquires certainty with eschatological consummation, Augustine's thought is methodologically governed by the following axiom: "faith seeks, understanding finds." ${ }^{38}$ For Henry, the Archi-revelation of absolute Life has always already taken place in what might be considered a "realized eschatology." The original $\lambda$ ó $\gamma$ os of life is "the phenomenological plenitude of life in its unshakeable positivity... In being crushed against itself in the invincible implosion of its pathos, life is an Archi-revelation, and in this way, it is the Way that leads to it. The Truth and the Way are indissolubly connected."139

Henry is not inspired by scholastic philosophy either. He does not reach the unknowable and invisible God through the ens/esse distinction of Aquinas. Defining God as ipsum esse subsistens omnibus modis indeterminatum would be to remain in a framework governed by ecstatic intentionality. ${ }^{140}$ This is the case because the "paradigm for understanding existence" (esse) is a capacity "to relate oneself to

\footnotetext{
135 Henry, Material Phenomenology, op. cit., p. 95.

136 Hans Urs von Balthasar, Love Alone is Credible, D. C. Schindler trans. (San

Francisco, California: Ignatius Press, 2004), p. 15.

137 Augustine, Concerning the City of God against the Pagans, Henry Bettenson trans. (London, England: Penguin Books, 2003), VIII.1.

138 Augustine, De Trinitate, Edmund Hill trans. (Hyde Park, New York: New City

Press, 1991), p. 396.

139 Henry, Material Phenomenology, op. cit., p. 97-8.

140 Thomas Aquinas, Summa Theologica, Ia, q. 11, a. 4.
} 
existence."141 Finally, and most of all perhaps, Henry's Christian philosophy bears little resemblance to Kant's Religion within the Boundaries of Mere Reason. For Kant, the pure philosophical doctrine of religion is form fitted to practical reason; that is to say, the trappings of biblical revelation give way to a purely ethical core. Henry emphatically declares: "everywhere in Christianity, the ethical is subordinated to the order of things." 142 For Henry, there is no conflict between the philosophical and theological faculties as in Kant. On the contrary, the revelation of God as recorded in the New Testament is essentially indistinguishable from the Archi-revelation of absolute Life, which is outlined in his project of "material phenomenology." ${ }^{143}$ As Henry triumphantly concluded in his Material Phenomenology, "all possible reality, including the reality of nature, the cosmos, the other, the absolute and even God, only become actual by being situated in Life." 144

Let us be clear that, for Henry, God is not simply revealed through the filter of Life, as if anything were antecedent to God. To the contrary: for Henry, God is Life, in its absolute sense, which is to say that the only legitimate sense of God is coordinate to the concept of self-affection in its strong sense. "The concept of self-affection as life's essence implies," Henry tells us, "the absolute sufficiency of its radical interiority-experiencing only itself, being affected only by itself, prior to any possible world and independently of it."145 That is to say, God is Life to the extent that it absolutely and reciprocally engenders itself and experiences itself (that is, affects itself). But, if all possible reality is actualized only through Life, are we to infer from this that humanity is none other than God? Or, conversely, does this render theology the anthropomorphism par excellence? Is the concept of Leib malleable enough to accommodate the difference between God and humanity? In other words, can we distinguish between God's Life and human life, even if it arises in imago Dei? Or does Henry's notion of Leib unwittingly conflate God and humanity? God's Life and the life of God's children are distinguished for Henry according to the distinction between active and passive self-affection. Unlike God, human life does not affect itself of its own accord. "I do not affect myself absolutely, but, precisely put, I am and I find myself self-affected. Here we find the weak sense of the concept of self-affection, the one proper to comprehending the essence of man, rather than to comprehending God's." ${ }^{146}$ God's Life is precisely the absolute self-affection through which human life becomes effective-passively. Human life always refers to God's Life, which refers to itself. We may wonder whether this distinction does justice to the infinite qualitative difference between God and the world as understood by traditional Christianity. Nevertheless, we may conclude that Leib is the organizing principle for Henry's philosophy of Christianity, including and especially John's affirmation that "God is love."

141 David Burrell, Knowing the Unknowable God: Ibn-Sina, Maimonides, Aquinas (Notre Dame, Indiana: University of Notre Dame Press, 1986), p. 32.

142 Henry, I am the Truth, op. cit., p. 26.

143 Henry, I am the Truth, op. cit., p. 13.

144 Henry, Material Phenomenology, op. cit., p. 94, my emphasis

145 Henry, I am the Truth, op. cit., p. 105.

146 Henry, I am the Truth, op. cit., p. 107. 
Before we explicitly analyze Henry's explication of John's affirmation, let us note some areas of concern in regards to Henry's system since these problems directly bear upon the notion of love. First, let us question its coherence from a philosophical perspective. On the one hand, he posits two irreconcilable orders: 1) "the non-ek-static and pathetic revelation of life," which is an auto-affective experience, and 2) "the letting-be-seen internal to and presupposed by the logos" of the $\varphi \alpha$ เvó $\mu \varepsilon v o v$, which is a hetero-affective experience. ${ }^{147}$ Yet, on the other hand, he claims that transcendent being is in fact only made possible by the immanent life of absolute subjectivity. ${ }^{148}$ Are they thoroughly irreconcilable orders of reality then? More radically, Henry claims that the "truth" of the world is "emptied of its own substance, unreal." 149 Contrastingly, the Truth of Life is defined as "manifestation grasped in its phenomenological purity."150 That is to say, despite Henry's positing of two irreconcilable orders, Life is ultimately the decisive manifestation of reality while transcendent being is only an illusion. This is a type of monism, which destroys any integrity of the order of being.

This brings us to our second criticism: if we are to grant the integrity of each of these domains, then we must wonder at their relationship. Henry seems either incapable or unwilling to clarify their connection. In what manner does transcendent being draw its possibility from the radically immanent, transcendental life of absolute subjectivity? Furthermore, how might a manifestation in the realm of the world provoke a reduction from the transcendent world to immanent life? In other words: if these irreconcilable orders provide completely different standards of truth, then how are we supposed to "learn" that Life's Truth is more essentially true than the truth of the world? At times, Henry seems to imply that both orders are fundamentally irreducible to one another, and perhaps equiprimordial. It seems that the aporia is more intractable than that of the Meno. This is, of course, massively important for a philosophy of Christianity in which the visible face of Christ is meant to convert one's gaze to the invisible Kingdom of God. Thirdly, why should we follow Henry in granting priority to non-intentional life over and against the world? On the one hand, this seems tenuous from a philosophical perspective. Are not the relational aspect (intentionality) and the impressional aspect (affective material) equally real and essential elements of the cogito? On the other hand, from the perspective of Christianity, it seems that a philosophy congruent with the biblical revelation must accept the "relating-to" of intentionality as an equally irreducible element of the cogitatio along with enstatic $\pi \alpha \dot{\theta} \theta$ os.

This third criticism brings us to the heart of this essay's concern: from the perspective of the New Testament, which philosophy of love - if any at all - is harmonious with biblical revelation? How does Henry characterize love and what is its significance within his unique philosophical system? To reiterate, Henry implicitly disagrees with the Kantian position, which claims that "love resides in the will and not in the propensities of feeling, in principles of action and not in tender

147 Henry, Material Phenomenology, op. cit., p. 90.

148 Henry, Material Phenomenology, op. cit., p. 81.

149 Henry, I am the Truth, op. cit., p. 29.

150 Henry, I am the Truth, op. cit., p. 25. 
sympathy; and only this practical love can be commanded."151 In addition to prioritizing ethics over divine self-manifestation, Kant's theory of love downplays its affective character. Henry and Kant thus part ways. Would the Aristotelianism of Aquinas therefore be more congenial to Henry considering that Aquinas grants serious ontological importance to the affections? Citing Augustine's De Moribus Ecclesiae Catholicae, Aquinas defines charity thus: "caritas est virtus quae, cum nostra rectissima affectio est, coniungit nos Deo, qua eum diligimus." 152 Cast in a teleological framework, virtue transpires in the sphere of ecstatic intentionality. Theological virtue is the active participation of the human agent in the divine esse according to the limitations of being human. For Henry, affectio is not the principle of self-movement towards an external telos; rather, affectio is without telos and constitutes the self's manifestation to itself. Invoking affections is therefore to the point because Henry defines love in this way:

Experiencing oneself as Life does is to enjoy oneself. Enjoyment ... is homogenous phenomenological material, a monolithic affective body whose phenomenality is affectivity as such... According to Christianity, God is Love. Love is nothing other than the self-revelation of God understood in its pathētik phenomenological essence, specifically, the self-enjoyment of absolute Life. This is why the Love of God is infinite love in which he eternally loves himself, and the revelation of God is none other than this love. ${ }^{153}$

God's children must love their own immanent life just as God loves God's own Life albeit in a uniquely absolute and infinite manner. Yet how could a fundamentally non-teleological understanding of reality make sense of God's redeeming action across history or the very phenomenon of Christ's outpouring of divine love?

\section{§15: The biblical definition of life ( $\Psi v x \eta$ redeemed as $\zeta \omega \eta$ )}

Having read Henry's I Am the Truth, one must be struck by the noticeable dearth of serious reflection upon Jesus' Passion, which is the concrete expression of the divine outpouring of love. Henry seems either unwilling or incapable of grasping its centrality. We venture to suggest the latter thesis. Depicting himself as the "good shepherd" who unconditionally tends his flock, Jesus tells his disciples "I lay down my life ( $\psi \cup \chi \eta ́ v)$ in order to take it up again." 154 This he does of his own power or authority: $\varepsilon^{\chi} \chi \omega \varepsilon^{\prime} \xi o v \sigma i ́ \alpha \nu$. As is well known, this statement on self-sacrifice prefigures his Passion wherein Jesus allows himself to be crucified in the manner of a common criminal. Is Jesus motivated by the abiding plenitude of his concrete life? Or is he motivated by a far more mysterious but nonetheless more credible reason?

151 Kant, Grounding of the Metaphysics of Morals, op. cit. p. 12.

152 Aquinas, Summa Theologica, IIaIIae, q. 23, a. 3, citing Augustine's City of God, XIV.7.

153 Henry, I am the Truth, op. cit., p. 31.

154 John 10:17. 
We must note that, in the biblical context, $\psi u \chi \eta$ takes a different meaning than in the Greek context. In the Phaedo, Socrates convinces his interlocutors that the soul, although separated from the body at death, "is most certainly deathless and indestructible and our souls will really dwell in the underworld." 155 Just as one's soul preexisted its embodied state, ${ }^{156}$ the soul (of a philosopher) enjoys postmortem immortality. However, as Paul reminds the Corinthian community, the meaning of $\Psi u \times \eta$ is derived from the Genesis narrative wherein "the Lord God formed man (adam) from the dust of the ground (adamah) and breathed into his nostrils the breath of life (neshemah); and the man became a living being (chay nephesh)."157 Iuxท́ therefore does not mean "embodied soul" as it does for Socrates; rather, it means living being - the materiality of the earth drawing its very life from the inspiration of God. $\Psi v \chi \eta \dot{~ i s ~ t h e ~ e s s e n t i a l ~ u n i o n ~ o f ~ \zeta \omega \eta ' ~(s p i r i t u a l ~ l i f e) ~ a n d ~ ß i ́ o s ~}$ (physical life), which exist as non-independent parts within human being. In other words, the biblical $\Psi u x \eta$ means everything that is definitive of concrete human life corporeality, affections, rational thought, volition and finitude - without being tied to any metaphysical consideration of a disembodied, immortal soul. It also means that the center of one's $\psi v \chi \eta^{\prime}$ is somehow always already related to the source of that very life, namely, God (Yahweh Elohim). It is here that we find the primary intimation of the biblical definition of humanity as esse coram Deo. It is within this highly specific anthropological framework that the Christ-event takes place.

Jesus, though trusting his heavenly Father, risks the permanent loss of this very life. This he does out of obedience to God but also out of love for fallen humanity. Jesus cannot rely upon the comfort of a putatively indestructible soul that might enable him to "love" humanity from the disinterested and disengaged perch of the philosopher. In the face of a tyrannical regime, Jesus does not consume hemlock with serene confidence in the soul's affinity to immutable wisdom. To the contrary, as recounted in the Passion narratives, Jesus seems to be existentially gripped by the impending loss of his very life. And, united to Jesus, the believer is faced by the same situation.

Henry is similarly uncommitted to any metaphysical conception of a hypostatized, immortal soul; he prizes concrete human life - albeit for unusual reasons. But, can he account for the New Testament understanding of Jesus' selfsacrifice, which expresses the outpouring of divine love? For Henry, the autarkic

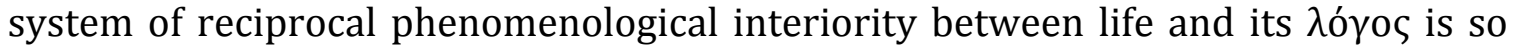
decisively absolute that he seems completely blind to any biblical verses that might suggest Jesus was motivated otherwise. In his famous Christological hymn, Paul reminds the community at Philippi that Jesus Christ, "though he was in the form of God, did not regard equality with God as something to be exploited, but emptied himself, taking the form of a slave, being born in human likeness. And being found in human form, he humbled himself and became obedient to the point of death - even

155 Plato, Phaedo, in the Complete Works, John M. Cooper ed. (Indianapolis, Indiana: Hackett Publishing Company, 1997), 107a.

156 Plato, Phaedo, op. cit., 76c.

157 Cf. Genesis 2:7 and I Corinthians 15:45. 
death on a cross." 158 The contrast with Henry could not be any starker. For Henry, life is a plenitude that is to be embraced and he cannot fathom the self-sacrificial meaning entailed in statements such as Jesus "became obedient to the point of death." Erotic immanence is far less convincing as an interpretation of the cross. That is, Henry's fundamental inability to grasp Pauline Christology consists in his prioritizing the non-intentional over the intentional. It is precisely the latter that better comprehends Jesus' loving embrace of the cross.

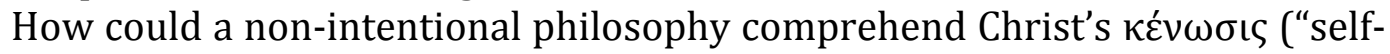
emptying")? The Pauline hymn seems to imply an ek-static and teleological relationship. While nevertheless remaining God, the Son leaves the Father and enters the world for the sake of redeeming fallen humanity. Only within an intentional framework, can the Christian thinker make sense of the incarnation and its soteriological significance. Second, let us interrogate the situation from the standpoint of the believer. For Christianity, love of God is not the immanent upsurge of $\pi \alpha \dot{\theta} \theta$ os from within absolute subjectivity itself. To the contrary: divine love is revealed to the believer - in the face of Jesus Christ - wholly from beyond. Thus, rather than codifying love as the immediate self-enjoyment of absolute life, a plausible account of Christian love requires us to understand the gaze of God as counter-intentional, to which the believer is called to respond to the grace of God by following the example of Jesus Christ. While certainly always already there, Christianity argues that life isn't simply to be embraced - "crushed against itself in the invincible implosion of its pathos." 159 Rather, life is to be donated towards one's neighbors for their own sake. This is the Way. It is the loving response to God's grace and it requires an intentional conception of the self. Therefore, the essence of loving self-sacrifice is not the abiding plenitude of life and its erotic immanence but the ability to "look not to your own interests, but to the interests of others." ${ }^{160}$ In this manner alone, Paul exhorts the Philippians to imitate Jesus Christ - the one who reveals the very meaning of human life. "Do nothing from selfish ambition or conceit, but in humility regard others as better than yourselves." In this, Levinas seems to be closer to the mark than Henry.

Levinas, as we have seen, is committed to an utterly other-regarding philosophy. Living beings are separated by an infinite distance, which is characterized by one's absolute non-indifference and interestedness vis-à-vis the other. At first blush, Jesus seems to preeminently exemplify this philosophy in all of its profundity. That is to say, if infinite responsibility is the very meaning of human life, then Jesus is its paradigmatic representative. As such, Christians must imitate Jesus in all that they do. However, is it really possible to conceive of humanity without some degree of "selfishness"? Is action possible without some view to the self? Is this even desirable or livable? These are important criticisms to bear in mind. However, we will not address the philosophical status of Levinas' notion of desire as situated entirely beyond unsatisfied need. Rather, we will focus on its congruity with biblical thought.

158 Philippians 2:6-7.

159 Henry, Material Phenomenology, op. cit., p. 98.

160 Philippians 2:4. 
In contradistinction to Levinas, life and enjoyment are central categories for Christianity. Let us begin with life. Levinas argued against Heidegger that

life is not the naked will to be, an ontological Sorge for this life. Life's relation with the very conditions of its life becomes the nourishment and content of that life. Life is love of life, a relation with contents that are not my being but more dear than my being: thinking, eating, sleeping, reading, working, warming oneself in the sun. ${ }^{161}$

The joy of living, for Levinas, is not an accidental feature of being human; rather, it manifests a certain surplus over being - the very value of life for the independent ego seeking satiety. Hence, being is sometimes risked for the sake of happiness. Life is loved only to the extent that it is an enjoyable accomplishment (active) of the sovereign ego and not as simple "lack of disturbance" (Epicurean $\alpha \tau \alpha \rho \alpha \xi i ́ \alpha)$. For Levinas, this enjoyment that is constitutive of life is nonetheless indicative of an autochthonous ego, which is to be de-prioritized for the sake of the other. Agreeing with Levinas, Christianity argues that the meaning and value of life does not merely consist in the enjoyable persistence in being. Yet the utter de-prioritizing of one's life does not seem to be congruent with Christian thought: as Henry rightly points out, life seems to be an ultimate concern for Jesus. "Very truly," Jesus tells his disciples, "anyone who hears my word and believes him who sent me has eternal life

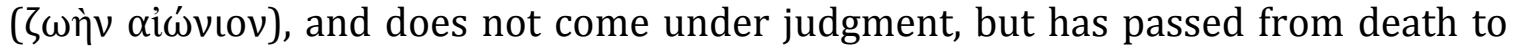
life."162 The very purpose for which the Son was sent into the world was to bring everlasting life - $\psi u \chi \eta ்$ redeemed as $\zeta \omega \eta$. We will return to these two notions of life later. Nevertheless, what separates Christianity from the thought of Levinas and Henry is the manner by which life is to be gained.

The fulfillment of life is revealed in the phenomenological situation of enjoyment. Albeit in complicated fashion, this is no less true for Christianity. Jesus prayerfully implores his heavenly Father to grant complete joy to his faithful disciples. ${ }^{163}$ And, the author of John's first epistle tells his community that he is "writing these things so that [their] joy may be complete." 164 How is joy related to fulfillment? Let us begin with the soul's essential dynamism. Following Aristotle, Aquinas defines love (amor) in the following way:

The first change wrought in the appetite by the appetible object is called "love" [amor], and is nothing else than complacency in that object; and from this complacency results a movement towards that same object, and this movement is "desire" [desiderium]; and lastly, there is rest which is "joy" [gaudium]. ${ }^{165}$

\footnotetext{
161 Levinas, Totality and Infinity, op. cit., p. 112.

162 John 5:24.

163 John 17:13.

164 I John 1:4.

165 Aquinas, Summa Theologica, IaIIae, q. 26, a. 2.
} 
In an extended sense, amor is the definitive affect of the soul. While Aquinas might share a certain intellectualism with Husserl, Aquinas determines the soul as essentially affective. In this, Aquinas is of one mind with Pseudo-Dionysius and Greek philosophy. ${ }^{166}$ Amor is a passion produced by the desired object and therefore sets the soul in motion. It aims at both sensible and intelligible objects alike. In a narrow sense however, amor has its seat in concupiscence-the sensual appetite. Dilectio, on the other hand, is the specific love that is proportioned to rational objects and has its seat in the faculty of the will. ${ }^{167}$ Dilectio therefore regulates amor concupiscentiae. Nevertheless, having chosen the good (bonum), the passion of love (passio amoris) is satisfied as joy (gaudium). Joy is thus the affective tonality that is revelatory of genuine fulfillment. Yet the joy of which Jesus speaks is the joy that follows from caritas, which is proportioned to God - not simple love (amor), which is proportioned to any appetible object. In other words, the most authentic fulfillment flows from one's relation to the sole "object" that can provide complete rest, namely, God.

For Aquinas, charity (caritas) is the perfection of love (amor) wherein the soul is affected by God and moves towards friendship with God. ${ }^{168}$ Suffused with passion, charity seeks to quench its restless strivings through loving communion with God. Charity is thus satisfied as face-to-face enjoyment of God. Just as amor is satisfied by the good (bonum) in the case of natural virtue, the desiderium naturale visionis beatificae is satisfied in the blessedness of face-to-face vision of God, which is accomplished in charity. Visio Dei is precisely the comprehensive contemplatio, which quenches the very heart of the soul - not as a possession, but as an ongoing (eternal) relationship. Beatitude is thus true happiness and joyful satisfaction vis-àvis God. Levinas of course rejects this framework.

Let us be clear: for Christianity, the meaning of human life is not envisioned simply as the enjoyable accomplishments of an autochthonous ego thereby reducing God to yet another object of its needs. In this, Christianity parallels Levinas. Human life is not fulfilled as Dasein's ecstatic care for itself (Heidegger). That is to say, human beings do not simply flourish through usable goods, which are ontologically conditioned by Dasein's being-in-the-world. Nor is human life fulfilled in the immemorial plenitude of absolute life's affective self-embrace (Henry). To the contrary: for Christianity, humanity is utterly dependent upon God, ${ }^{169}$ who remains utterly transcendent, and must respond to God's love in order to be sustained in existence. God is neither known nor consumed as any mundane object (Husserl) but is desired as wholly other. As we saw earlier, biblical anthropology already implied that one's very being ( $\left.\psi u \chi \eta^{\prime}\right)$ comes from an outside source, namely, the inspiration of God. To be human is to be coram Deo. Yet, as $\psi u x \eta ́$ discovers its transcendental possibility for autonomous activity, which is nonetheless a gift from God, $\psi v \chi \eta$ returns to itself under the illusion of self-sufficiency. This characterizes sin. As Jesus teaches his disciples, $\Psi u \chi \eta$ must be sacrificed for the sake of $\zeta \omega \eta$. "Those who want

166 Aquinas, Summa Theologica, IaIIae, q. 28, a. 6.

167 Aquinas, Summa Theologica, IaIlae, q. 26, a. 3.

168 Aquinas, Summa Theologica, IIaIIae, q. 23.

169 Cf. Matthew 6:33. 
to save their life ( $\psi u \chi \eta ́ v$ ) will lose it, and those who lose their life ( $\psi u \chi \eta ́ v)$ for my sake will find it." 170 As $\psi u \chi \eta$, life does not subsist. It must be sacrificed for another (God or the neighbor) in order to pass from death to life ( $\zeta \omega \eta)^{\prime} \cdot{ }^{171} \zeta \omega \eta$ is the relational understanding of life, while $\psi v x \eta$ r represents the life of the punctuated and autochthonous self. The meaning of human life is therefore loving self-sacrifice. This is not to say that one's concrete $\psi v \chi \chi^{\prime}$ is sacrificed for the sake of an abstract $\alpha \dot{\alpha} \theta \rho \omega \pi \mathrm{s}$ or dissolved into the Sein of the seiendes. To the contrary: $\psi u x \eta$ is sacrificed for the sake of the Son, and, by extension, for the sake of other concrete human beings (i.e. the neighbor). That is to say, $\zeta \omega \eta$ is understood as the believer's living response to the loving advance of God. Human life is thus determined as esse coram Deo and humanity's raison d'être is characterized by friendship with God (and, by extension, the neighbor). Hence, $\psi u x \eta$ is redeemed and is sustained beyond death only as $\zeta \omega \eta$. This is true because the very meaning of life is derived from the communal fabric at the heart of existence, not from the naked conatus essendi or the absolute plenitude of affective life. This is revealed throughout Jesus' life and is confirmed in his resurrection. Accordingly, in an essential dissimilarity to Henry and Heidegger, Christianity understands the fulfillment of life's internal dynamism to be dependent upon the grace of God. The lord "satisfies you with good as long as you live ... seek his presence continually."172 Thus, it would be inaccurate to characterize Christianity as life denying. On the contrary, given the inner dynamism of life, life is joyful and self-affirming precisely in relation to another. Christianity thus inverts the order of priority: one's being is risked for the sake of another and this constitutes personal flourishing. That is to say, the meaning of the self is derived from another;

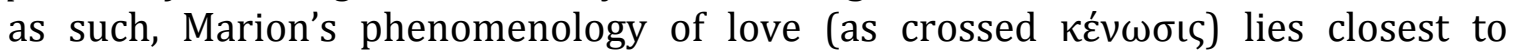
Christianity.

Admittedly, for pre-eschatological humanity (which is characteristically both $\psi u x \eta \dot{~ a n d} \zeta \omega \eta$ ), complete joy remains a promise. To be sure, the believer is already affected by the presence of God, concretely in the person of Jesus Christ. That is, while remaining utterly unique and wholly other, God's love is authentically felt in a pre-eschatological experience of joy. This is because spiritual communion with God is presently inaugurated within temporal existence $\left(\psi v x \eta^{\prime}\right) \cdot{ }^{173}$ Yet the perfect joy of

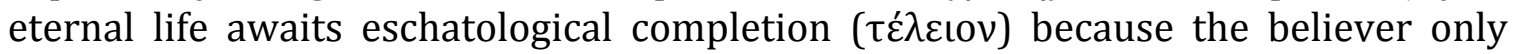
sees God "in a mirror darkly." No matter how sharp one's gaze can be focused on Jesus in the life of faith and love, God remains nonetheless invisible. While the Christian is thankful for the grace that is dispensed in the Christ-event, true peace and lasting joy are only consummated by one's vision of God face-to-face. ${ }^{174}$ This is the eschatological event par excellence - the event in which the deepest longings of humanity are satisfied by the presence of God ( $\pi \alpha \rho o v \sigma i \alpha)$, the most thoroughgoing theophany that also enables faith's gaze to cease its restless conversion. Time reflects this dynamic and teleological relation. While God remains dialectically

170 Matthew 16:25.

${ }^{171}$ Cf. John 5:24.

172 Psalm 103:5 and 105:4.

173 Cf. John 5:24.

174 I Corinthians 13:12. 
absent, humanity must await the promise of God's self-presence. Despite this eschatological qualification, God's abiding presence remains the source of the self and its true joy. "Beata vita hominis Deus est."175 Eschatological or not, joy is the affective tonality of genuine self-fulfillment. "The joy of the Lord is your strength."176 Thus, for Christianity, risking one's being for the sake of God (and neighbor) constitutes genuine happiness.

Having briefly distinguished Christian thought from the philosophies of Levinas and Henry, let us interrogate the possibility of the experience of God since the aforementioned existential analytic of life's meaning as esse coram Deo presupposes just such a possibility. As suggested by Aquinas, the passio amoris is stirred only by the presence of an appetible object. Accordingly, we might address the following question to Christianity: if the passio amoris is stirred only by an actual encounter, then how precisely is God encountered in the person of Jesus Christ? That is to say, what makes possible the manifestation of divine love ( $\dot{\alpha} \gamma \alpha \dot{\pi} \pi \eta)$ to human beings? Admittedly for Christianity, while Jesus Christ is considered to be the primary instance of divine self-revelation, God is not seen as God is in God's self. Does this mean that God's presence in Jesus is merely inferred (by way of simple verbal communication) or accepted blindly? Not quite since Christians do believe that $\grave{\alpha} \gamma \alpha \dot{\alpha} \pi \eta$ is genuinely and authentically experienced, albeit according to the eyes of faith. Thus, let us specify a fundamental aspect of our question: how must humanity be (as a dative of manifestation) such that God's self-revelation might be considered to credibly penetrate into the realm of human experience without eviscerating God's status as wholly other? Or, more broadly, if God could be experienced, what would "God" mean? And, what does that have to do with Jesus?

\section{§16: Theo-logy, or the experience of God?}

In view of explicating the possibility of the "experience of God," let us outline some formal requirements for such an experience by taking the very word theology as our leading clue. From a philological perspective, theology is a composite word

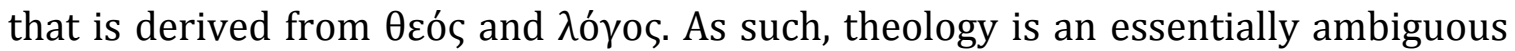
term. It can either mean "the logic that is applied to God" - accordingly, theo-logy thereby inviting the following question: whose logic, which rationality? No matter the answer, this construal of theology submits divine revelation to an anterior (phenomeno-) logic. By contrast, theology can mean "God's self-interpretation" accordingly, theo-logy. Aquinas favors this latter construal in his commentary on Boethius' De Trinitate, where he rigorously distinguished the "scientia divinae veritatis" from the mode of knowledge of (pre-Christian) philosophy. Let us quote his explanation at length.

One is according to our mode of knowledge, in which knowledge of sensible things serves as the principle for coming to a knowledge of divine; and it was in this way that the philosophers handed down a traditional science of divine things, calling first philosophy a divine

175 Augustine, City of God, op. cit., XIX.26.

176 Nehemiah 8:10. 
science. The other mode is according to that of divine things themselves as they are understood in themselves. This is, indeed, a mode of knowledge which we cannot possess perfectly in this life; but there is for us, even in this life, a certain participation and assimilation to such a cognition of divine truth, inasmuch as through the faith which is infused into our souls we adhere to the very First Truth on account of Itself. ${ }^{177}$

Aquinas goes on to state that the first principles of divine science are prior to the first principles of traditional philosophy because the latter are quasi-conclusions that are derived from the former. Nevertheless, we see that Aquinas distinguishes two fundamentally different modes of knowledge: the mode of knowledge that is coextensive with worldly manifestation and the mode of knowledge wherein God understands God's self. Thus, to be true to its "object," rational reflection on God must be uncompromisingly organized around God's unique self-revelation.

Let us briefly highlight six aspects of Aquinas' determination of the divine

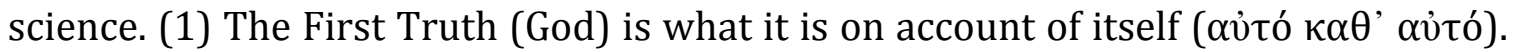
(2) Consequently, this First Truth gives itself, of its own accord and in its own manner. (3) In order to "see" that truth, the believer requires a conversion of the gaze (faith), which is purged of worldly logic and manifestation (pagan philosophy). Yet it must be emphasized that the believer's gaze is always dependent upon the anteriority of the gift of revelation, not vice versa. (4) What's more, God is infinitely beyond the believer's gaze; hence, the divine mode of knowledge cannot be perfectly possessed in this life. Aquinas emphasizes this point most forcefully in his introduction to the commentary. (5) Nonetheless, in virtue of "infused" faith, there is legitimate, pre-eschatological experience of divine truth; hence, there is a certain participation and assimilation to the cognition of divine truth. (6) Finally, in order to be a genuine experience, faith must be uncompromisingly attendant to the gift of the divine presence in all of its particularity, that is, in the person of Jesus Christ. The "object" of divine revelation cannot be bracketed and reduced because the other governs the relation at all moments. Like Isaiah's sui generis vision of the peaceable kingdom, theology must prophetically announce the limits of the transcendental reduction and its impotence before the God.

Following these requirements, Christianity rejects the primacy of created being and contrasts divine self-revelation with worldly manifestation. Henry was surely right to reject the ego's active horizon of visibility as the primary modality of divine revelation. Yet Christianity goes further. God is not submitted to any mode of human knowing - whether it is a system of signs $(\sigma \eta \mu \varepsilon เ \alpha)$ or theoretical knowledge $(\dot{\varepsilon} \pi \iota \sigma \tau \dot{\mu} \mu)$ or worldly manifestation $(\dot{\alpha} \lambda \hat{\eta} \theta \varepsilon\llcorner\alpha)$ or "authentic" modes of existence (Leib or Dasein). As Paul tells the Corinthians,

It is written, "I will destroy the wisdom of the wise, and the discernment of the discerning I will thwart." Where is the one who is wise? Where is the scribe? Where is the debater of this age? Has not

${ }^{177}$ Aquinas, Commentary on Boethius' DeTrinitate, 2.2. 
God made foolish the wisdom of the world? For since, in the wisdom of God ( $\sigma \circ \varphi$ í $\alpha$ tou $\theta \varepsilon \circ u$ ), the world did not know God through wisdom, God decided, through the foolishness of our proclamation, to save those who believe. For Jews demand signs and Greeks desire wisdom, but we proclaim Christ crucified, a stumbling block and foolishness to Gentiles, but to those who are called, both Jews and Greeks, Christ the power of God and the wisdom of God. For God's foolishness is wiser than human wisdom, and God's weakness is stronger than human strength. ${ }^{178}$

Not only does Paul indicate that divine wisdom is higher than worldly wisdom but he also seems to deconstruct worldly wisdom at the same time. No worldly philosophy has proven efficacious at uniting human beings, either with God or amongst themselves. Sin rends the fabric of creation apart thereby thwarting the discernment of the "wise." In their own ways, Paul, John and James criticize native modes of existence - see Galatians 5:16-21, Ephesians 5:3-20, I John 2:15-17 and James 3:13-4:12, for example. We may summarize their writings thus: if one's actions are aimed at worldly goods or mundane objects for their own sake or merely in view of self-fulfillment, then natural desire is twisted into sin. But doesn't philosophical wisdom present itself as the prudential know-how of life and therefore as the paradigmatic virtue that leads to social harmony? Even though philosophical wisdom is an implicit attempt to curb the effects of selfish desire through the process of rational abstraction, we must understand that

neither religious philosophy nor existence can provide the criterion for the genuineness of Christianity. In philosophy, man discovers what is humanly knowable about the depths of being; in existence, man lives out what is humanly livable. But Christianity disappears the moment it allows itself to be dissolved into a transcendental precondition of human self-understanding in thinking or living, knowledge or deed. ${ }^{179}$

As wholly other, God cannot be measured by an anthropological or a cosmological yardstick. To the contrary, God is revealed in utterly unique and unexpected fashion, that is, through the cross of Jesus.

But, if humans naturally think in worldly ways, how is the believer to know that Jesus is the wisdom of God? Isn't Jesus precisely foolishness and a stumbling block? Isn't faith in Jesus dependent upon an antecedent understanding of what "God" means in the first place? Thus, the properly first question is, if God could legitimately be experienced, what does "God" mean? Or should we conclude that the experience of God is impossible because the alterity of God transcends even the otherness of other human persons?

1781 Corinthians 19-25.

179 Balthasar, Love Alone is Credible, op. cit., p. 51. 
John Caputo has outlined a clever but risky response to the problem of the "experience of God" by way of "the axiology of the impossible." In short, Caputo argues that we can experience God because, even though God transcends the conditions of possibility of experience, the very structure of experience seeks that which exceeds its very own horizons of constitution (that is, the phenomenon of the impossible). ${ }^{180}$ If true, this notion of experience, as aiming at that which exceeds its horizon of possibility, gives experience a paradoxical structure: that is, experience desires to experience that which cannot be experienced. Caputo is explicitly developing a famous thesis of Kierkegaard - the pseudonym Johannes Climacus, to be precise. As Climacus tells us in the Philosophical Fragments,

One must not think ill of the paradox, for the paradox is the passion of thought, and the thinker without paradox is like the lover without passion: a mediocre fellow. But the ultimate potentiation of every passion is to will its own downfall, and so it is also the ultimate passion of the understanding to will the collision, although in one way or another the collision must become its downfall. This, then, is the ultimate paradox of thought: to want to discover something that thought itself cannot think. ${ }^{181}$

Even though this seems to be a groundless assertion concerning the passion of the understanding, we might provide two citations in support of this view: one historical, one philosophical. In the Western tradition, the very word "experience" is etymologically related to the Greek word $\pi \varepsilon i \tilde{\rho} \alpha$, which means danger, risk, trial, adventure, peril, and, above all, experience. To have an experience, according to the West, is to expose oneself to something that shatters the limits of one's protentional horizon. And yet this etymology reflects a deep philosophical presupposition, namely, that consciousness is polarized towards transcendence. This does not include the rational understanding since, as we have seen, intentionality reorganizes sense impressions according to its own synthetic powers; as such, the horizon of representation is never exposed to risk and does not reach pure alterity. In short, reason does not "experience." Yet, as we have seen thus far, consciousness, qua है $\rho \omega \varsigma$ (Marion) or qua desire (Levinas), is nonetheless polarized ad extra - towards that which infinitely exceeds the horizons of comprehension. Caputo is therefore in tacit agreement with Aquinas, for whom God can only be viewed through the converted gaze of the eyes of faith, purged of the normal modes of this-worldly seeing, infinitely directed at that which exceeds its powers of vision. It precisely here, under

180 See John Caputo, "The Experience of God and the Axiology of the Impossible," in The Experience of God: A Postmodern Response, Kevin Hart and Barbara Wall eds. (Fordham University Press, 2005).

${ }^{181}$ Soren Kierkegaard, Kierkegaard's Writings. VII, Philosophical Fragments, or A Fragment of Philosophy and Johannes Climacus, or De Omnibus dubitandum est, Howard and Edna Hong trans. and ed. (Princeton: Princeton University Press, 1985), p. 37. 
the figure of the (phenomenally) impossible, that God might enter consciousness, which is already the passion for such as impossible experience.

For Caputo, God is to be found precisely where the experience of the impossible takes place. This claim has obvious scriptural basis: "for human beings it is impossible, but for God all things are possible" (Mt. 19:26). We are not talking about the merely improbable, which shocks but is nonetheless foreseeable, like recovering from a severe illness or being struck by lightning. We are talking about, in the first instance, that which shatters the authentic, reasonable and natural comportment of the virtuous human being (in-the-world). To that end, Caputo contrasts the $\varphi \rho$ óvıนо - the one who is in rational control over his or her life, even amidst changing circumstances, by governing their actions by the principle of the golden mean - with the three so-called "theological virtues," which are marked by a

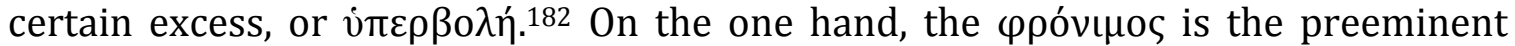
being-in-the-world, the one whose way of life is suffused with worldly-wisdom, and the one who knows how effectively to conduct their very own project of being. On the other hand, the person who lives by faith, hope and love, exposes themselves to the dangerous and the perilous - to the point of risking their very life. The impossible breaks into experience like madness, like Plato's $\mu \alpha v i \alpha$ - a madness that goes beyond the normal bounds of rational self-control. Concretely, the impossible is experienced in phenomenon such as loving one's enemies (that is, the unlovable); such as caring for the sick, the downtrodden and the dispossessed (that is, those who cannot return the favor); such as a religious leader forgiving a would-be assassin (that is, the one who threatened another's very life); or, such as granting salvation to sinners (that is, the ones who turned their backs on their own father). Love, mercy, forgiveness and hope are experienced as impossible, not in the sense that they are logically contradictory but in the sense that they exceed the normal modes of being-in-the-world.

Thus, in the experience of madness, adventure and excess (that is, in the experience of the impossible), one ought to look for God, where gifts are given unconditionally, limitlessly, and without hope of return. These experiences (of the impossible and unexpected gift) are precisely the concretion of the experience of the divine.

For God is the giver of all good gifts, above all if they are impossible. This is what we mean by God, what the name of God means, and it is this sort of limit-experience - a term that is in a certain sense redundant, that gives the name of God meaning, what we might call phenomenological content, which is in the truest sense of the word experiential... We look for God, as [Nicholas of] Cusa says, where the impossible happens. ${ }^{183}$

182 Cf. Caputo, "The Experience of God and the Axiology of the Impossible," op. cit., pp. 26-36

183 Caputo, "The Experience of God and the Axiology of the Impossible," op. cit., pp. 30-31. 
That is, God does not give himself according to worldly logic (as the rationallycalculating $\varphi \rho o ́ v(\mu о \varsigma)$ but as the Mad One who gave His only Son for the sake of sinful humanity. The wisdom of God transcends the wisdom of the $\varphi \rho$ óvıนo in the mode of its unexpected excess, which loves the ones who do not deserve love.

Let us highlight two things here. (1) With Caputo, we have clarified a central indecision (hence, ambiguity) at the heart of this paper. The other has meant either God or another human being. Yet we see that, under its theological dimension, the experience of the other is an experience of the impossible; hence, the experience of the other, if its logic follows the axiology of the impossible, is an experience of the divine. We have reversed the emphasis: we should not base our experience of God upon any human experience but we should base our experience of other humans upon the experience of God, the first impossible. To be precise: the experience of God is concretely united to an experience of the impossible, whether it is an experience of God as such (in liturgy or prayer, e.g.) or an experience of another human being (qua imago Dei, in neighborly love). (2) And yet the excess of the impossible does not strike the believer as irrational but as the answer to its inward groaning, its paradoxical desire for transcendence. God breaks into experience exactly where the desire seeks to transcend itself - either as the erotic, cosmic transcendence (Socrates) or the charitable, social transcendence (Marion). Thus, we ought to look for God where there is passion for transcendence. Is there a better

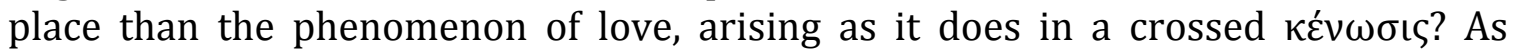
Caputo says, "the experience of God is given in the experience of love. But love is perfect not when love is drawn around a closed circle of friends and intimates, which makes perfect sense and is perfectly possible, but precisely when love is stretched to the breaking point of loving when love is mad and impossible. The God of love and the God of the impossible seem like a nice fit, a kind of prefit." 184 Only by way of the axiology of the impossible is the believer (as the dative of manifestation) able to receive the phenomenon of God's love ( $\dot{\alpha} \gamma \alpha \dot{\alpha} \pi \eta)$ without thereby eviscerating its $\kappa \alpha \theta^{\prime} \alpha$ vó integrity.

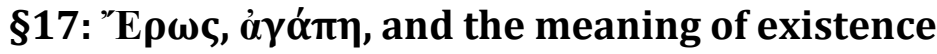

Where precisely should we discern such a prefit? As we shall see, revelation

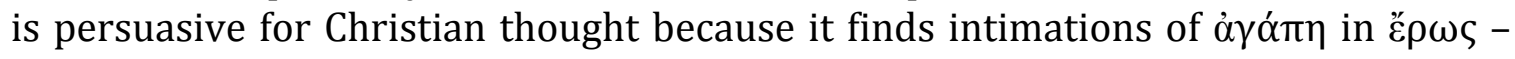
albeit only if perfected as caritas. That is to say, $\alpha \gamma \alpha \dot{r} \pi \eta$ is felt not as an emotional elation, say, but as recognition that $\dot{\alpha} \gamma \alpha \dot{T} \pi \eta$ freely fulfills the internal dynamic of $\tilde{\varepsilon} \rho \omega \varsigma$ - albeit in unforeseen ways. We must therefore search for such a prefit by seeing if the glory of transcendence already shines forth in the midst of worldly selfishness. To that end, Hans Urs von Balthasar, a $20^{\text {th }}$ century Swiss theologian, famously developed what he called a "theological aesthetic." For him, only in the realm of beauty do we find phenomena with the following traits: 1 ) beautiful objects possess their own peculiar logic irreducible to the ego's transcendental power of imagination and 2) despite their status qua other, beautiful objects nonetheless possess compelling plausibility by which the perceiving subject is enraptured. In Balthasar's theory, if the divine self-manifestation of love, which is utterly free and

${ }^{184}$ Caputo, “The Experience of God and the Axiology of the Impossible," op. cit., p. 36. 
absolute, is manifested in the incarnation, then we must follow the aesthetic approach to beautiful objects.

Already in the realm of nature, eros is the chosen place of beauty: whatever we love - no matter how profoundly or superficially we may love it - always appears radiant with glory; and whatever is objectively perceived as glorious - no matter how profoundly or superficially we experience it - does not penetrate into the onlooker except through the specificity of an eros. Both reciprocally related poles are transcended in the realm of revelation, wherein God's kenotically condescending Logos expresses himself as Love, Agape, and thus as Glory. ${ }^{185}$

God remains the integrating center of revelation; yet the perceiving subject is nonetheless enraptured and drawn close to God in loving intimacy. Where is the divine self-revelation revealed as credible, as displaying an ability to penetrate and grip the believer? Undoubtedly, it is है $\rho \omega \varsigma$, erotic transcendence. Let us elaborate.

As early as Plato's Symposium, love ('̋ $\rho \omega \varsigma$ ) can be understood in two senses. Let us briefly juxtapose them as starkly as possible. On the one hand, ع̋ $\rho \omega$ s refers to egotistical contentment. At its best, this form of है $\rho \omega \varsigma$ is reciprocal and aims at mutual beneficence (Pausanias' Aphrodite Urania). At its worst, this form of " $\rho \omega \varsigma$ is transmuted into the anguished care of Dasein for itself (Heidegger's Sorge). Formulated thus, one might be tempted to think that $\varepsilon \rho \omega \varsigma$ essentially conflicts with $\dot{\alpha} \gamma \alpha \dot{\alpha} \pi \eta$. As utterly self-emptying, altruistic and benevolent without hope of return, $\dot{\alpha} \gamma \alpha \dot{\alpha} \pi \eta$ precludes any erotic desire. However, this constitutes a gross simplification. To avoid an intractable conflict that risks rendering $\alpha \gamma \alpha \dot{\alpha} \pi \eta$ incredible, let us look at the second sense of "s $\rho \omega \varsigma$. Socrates caught sight of a nobler form of erotic activity. For him, the soul can be purified of its selfish desires through contemplation of

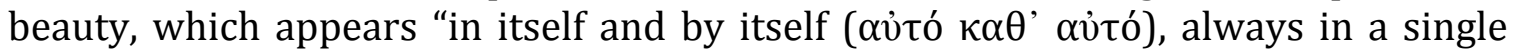
form." 186 It is here, only in the contemplative adoration of the Forms, that " $\rho \omega \varsigma$ finds repose. And yet it is the conflict between the two senses of है $\rho \omega \varsigma$ that enables $\alpha \gamma \alpha \dot{\pi} \pi \eta$ to fulfill the inner dynamism of é $\rho \omega \varsigma$.

Rooted in beauty and goodness, है $\rho \omega \varsigma$ is not mutually exclusive of $\varphi \iota \lambda i \alpha^{\alpha}$. To the contrary: " $\varepsilon \omega \varsigma$ precedes and makes possible $\varphi \imath \lambda i \alpha$, which is genuine love of and concern for another. To be sure, the true friend loves their friend only to the extent that that friend authentically participates $(\mu \varepsilon \tau \varepsilon \dot{\chi} \chi)$ in the Forms. Nevertheless, $\varepsilon \rho \omega \varsigma$ is not necessarily egocentric but can be genuinely other-regarding when it is based upon beauty and goodness. This view seems to be corroborated by Aristotle in book VIII of his Nicomachean Ethics wherein Aristotle argues that virtuous friendship is to be distinguished from friendships based upon personal needs and private gratification - utility and pleasure friendships, respectively. In similar fashion, to the

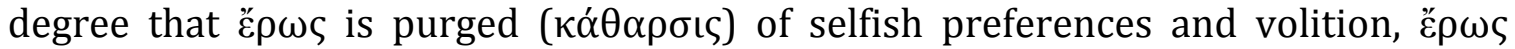
intimates $\dot{\alpha} \gamma \alpha \dot{\alpha} \pi \eta$ (God's unconditional concern for humanity).

185 Balthasar, Love Alone is Credible, op. cit., p. 54.

186 Plato, The Symposium, op. cit., 211b. 
We emphasize this ambiguity in the heart of $\varepsilon \rho \omega \varsigma$ (egocentric need vs. altruistic benevolence) because it is essential to the experience of God's selfrevelation as $\dot{\alpha} \gamma \alpha \dot{\pi} \pi \eta$. Balthasar argues that, in the phenomenon of self-renunciation, we "receive an intimation of the meaning of being itself as love ... [but] love is circumscribed by the limitations of nature." ${ }^{187}$ Let us elaborate. Patriotism, altruism and enduring communions - such as familial bonds and friendships - reflect the transcendent nature of love to the extent that they subordinate the punctuated and particular self. Human preferences do not seem to be necessarily constrained by an essential finitude - whether temporal or spatial. Nor do they seem to be fundamentally dominated by a compulsory view to the self. Rather, individual human beings can go beyond themselves (transcendence) for the sake of another (personalism) or for the sake of a collective whole (abstraction).

However, love is always tempered by the forces of nature. It is neither possible nor desirable to fully overcome one's contextual limits; nor is it possible to eliminate "selfish" preferences.

The other forces of existence retain power and domination over against love. When man absolutizes creaturely love at the expense of the agonistic forces of life, he contradicts himself in a biological and cultural sense, as Nietzsche has shown. The sphere of ordinary existence, the place where people interact, contains at best a middle position in which love and self-interest, love and nonlove, temper one another. ${ }^{188}$

At best, we see that $\tilde{\varepsilon} \rho \omega \varsigma$ reaches equilibrium with the agonistic conatus essendi; thus, the finitude of existence, in the sense of being riveted to the project of being, straightjackets love into a form of reciprocity and mutual beneficence. What's more, $u \chi \eta$ transmogrifies into "embraced self-centeredness" (pride) chosen under the illusion of self-sufficiency ("ye shall be as gods"). This characterizes sin. While one may be tempted to interpret nature as an impersonal source of evil, sin is always chosen and therefore personal. Thus, sin (pride) and finitude (conatus) perpetually circumscribe the limits of erotic transcendence. Nevertheless, barring the corrosiveness of personal sin, we still see that the erotic sphere constitutes a horizon of experience that is situated somewhere beyond the essential finitude of human nature.

It is only within this anthropological and metaphysical context that Jesus' Passion becomes credible as the unique revelation of God's love for humanity. We do not say that the Passion is intelligible because we do not wish to imply that reason can demonstrate the cross from certain principles or infer it from an array of human experiences. As we have said (following Aquinas), love is persuasive only as an actual encounter with a flesh and blood person and without appeal to the first principles of a deductive system. Accordingly, the believer can assent to divine love only in an act of faith. What does the cross purport to reveal? In all of its gruesome

187 Balthasar, Love Alone is Credible, op. cit., pp. 62-63.

188 Balthasar, Love Alone is Credible, op. cit., p. 64. 
particularity, the cross simultaneously exposes human sinfulness and displays genuine love. The former is revealed in all of its stark contrast to the latter. Specifically, while humanity exhibits its sinful warping of love into self-love, Jesus is obedient to his heavenly Father to the point of death. This self-denial for the sake of

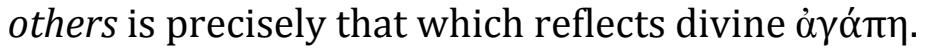

We must emphasize that God's love ( $\dot{\alpha} \gamma \alpha \dot{\pi} \pi \eta)$ is not circumscribed by the structures of finite, sinful being; this is what separates $\alpha \gamma \alpha$ ó $\pi \eta$ from है $\rho \omega \varsigma$ (and even caritas). Nor is $\dot{\alpha} \gamma \alpha \dot{\pi} \pi \eta$ constrained by temporal or spatial limits. To the contrary: divine $\alpha \gamma \alpha \dot{\alpha} \pi \eta$ is infinite and unconditional. It is expressed as unlimited compassion, forgiveness and mercy. It universally spreads to all peoples, in all places and at all times. It is constrained by nothing - including human rejection. While it is commenced in absolute freedom, it is executed without expectation of return which is to imply that God's love is not coextensive with worldly modes of reciprocity. Moreover, unlike है $\rho \omega \varsigma$, $\dot{\alpha} \gamma \alpha \dot{\pi} \pi \eta$ has absolute power over being (qua being). But, since existence always already has an erotic depth and texture, death is not the final word for loving self-sacrifice. It is precisely Jesus' resurrection confirms the pre-ontological power of love over being. That is to say, Jesus gives up his life

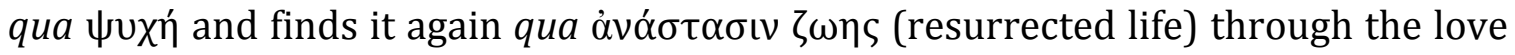
that he pours out to humanity. Z $\omega \eta$ outlasts and outstrips finite existence because its horizon of unfolding is not governed by the structure of being (qua being). Thus, the cross and resurrection - as non-independent moments in the one event of divine love - constitute $\alpha \gamma \alpha \dot{\pi} \pi \eta$ 's unanticipated yet credible difference from ह̌ $\rho \omega \varsigma$. It is unforeseen in its absolute freedom vis-à-vis sinful creation and in its infinite power over being and it is credible because it is recognized as the fulfillment of " $\rho \omega \varsigma^{\prime}$ internal dynamism.

\section{§18: Infinite Passion}

We are now in a position to understand the meaning of John's first epistle, which we will now quote at length.

Beloved, let us love one another, because love is from God; everyone

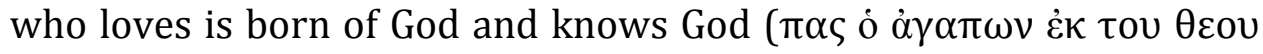

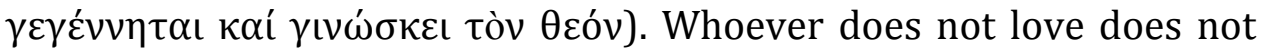

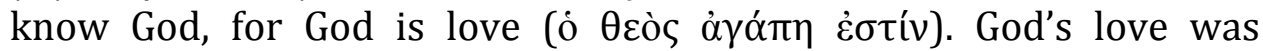
revealed among us in this way: God sent his only Son into the world so that we might live through him. In this is love, not that we loved God but that he loved us and sent his Son to be the atoning sacrifice for our sins. Beloved, since God loved us so much, we also ought to love one another. No one has ever seen God; if we love one another, God lives

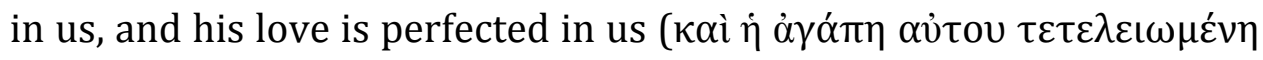
$\dot{\varepsilon} v \dot{\eta} \mu \nu v \dot{\varepsilon} \sigma \tau i ́ v) .189$

Emphatically, John declares that "God is love." This is the essential truth for Christianity and it has been decisively revealed in the Christ-event, which is

189 I John 4:7-12. 
inseparably crucifixion and resurrection. While $\dot{\alpha} \gamma \alpha \dot{\alpha} \pi \eta$ (as it is in itself) remains beyond all comprehension ("no one has ever seen God"), it is nonetheless expressed in the Son's kenotic condescension. On the one hand, divine love is revealed in the context of erotically structured existence and is credible as a result. The ultimate significance of God's infinite love is suggested from the depths of created existence. While, on the other hand, $\alpha \gamma \alpha \dot{r} t \eta$ distinguishes itself from है $\rho \omega \varsigma$ and is discovered to be infinite and absolute, unconditional and unconstrained by being. A $\gamma \alpha \dot{r} \pi \eta$ fulfills and elevates $\ddot{\varepsilon} \rho \omega \varsigma$. It is perfected as the self-sacrificial advance towards another. And yet, as suggested by the above passage, love is not only definitive of God (the infinite source of life) but is also epistemologically and "metaphysically" significant for the children of God: "everyone who loves is born of God and knows God." In other words, God is knowable only through love, non intratur in veritatem nisi per caritatem (Augustine); hence, the self must be (re) born as a lover (of the truth, Love). We need not trot out the (phenomenological) arguments about how the self be structured (as a dative of manifestation) such that this "knowledge of God" would even be possible. ${ }^{190}$ However, in order to supplement John's "phenomenological understanding" of divine love, let us seize upon an essential aspect of love's mode of understanding, namely, the infinite passion that yearns for God and subtends love's way of life.

As we saw in Plato's case, the Good and the Beautiful are decisively revealed to है $\rho \omega \varsigma$, which is structured as a passion or desire for contemplative satiety. In analogous fashion, $\dot{\alpha} \gamma \alpha \dot{\pi} \pi \eta$ is revealed to the "restless heart" (Augustine's inquietum cor), which is creation's essential yearning for the creator. ${ }^{191}$ In between the Christevent and the eschatological "second coming," the disciples "groan inwardly" and "wait with eager longing" for the full revelation of the glory of God. ${ }^{192}$ And yet creation has labored for consummation since time immemorial. Surging from the depths of one's being, this yearning to go beyond one's self constitutes an inchoate pre-understanding (prolepsis) of love such that $\alpha \gamma \alpha \dot{\pi} \pi \eta$ can be authentically recognized. All of this suggests the following: yearning considered in itself and as such (passio amoris) is an a priori condition of possibility for the subjective reception of and intentional response to divine love ( $\dot{\alpha} \gamma \alpha \dot{\alpha} \pi)$. To the degree that it is a passionate modality of existence, yearning is an originary givenness that is simultaneously affective and "intentional."193 That is to say, enlivened and informed by God's creative presence, restlessness is impressed into the heart of being thereby enabling an adequate response to the revelation of divine love. Let us elaborate.

As we saw from John's epistle, one must be "born of God" in order to "know" God. Being born of God means having been given the capacity to love and to be

${ }^{190}$ Cf. especially $\S \S 10-11$, above.

191 See Augustine, The Confessions, Maria Boulding trans. (New York: Vintage Books, 1998), Book I.

192 Cf. Romans 8:18-25.

${ }^{193}$ I place intentionality in scare quotes in order to indicate that intentionality's polarization of consciousness towards transcedence must conform to the formal

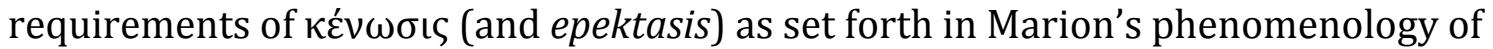
love. Again, cf. especially §§ 10-11, above. 
loved. In the case of perception, intentionality is an absolute given. To be sure, "objects" are revealed according to the appropriate "intentionality." Thus, we might be tempted to understand love in the following way: while natural objects are only perceptible by way of the perceptive mode of intentionality, love is only recognizable by way of love. But, for Christianity, love is not a simple modality of theoretical intentionality. Let us note an essential contrast: whereas the intentional subject organizes retentions and protentions according to its apperceptive unity (passivity that is already an activity), the loving subject "is organized" (pure passivity) by love's prior advance. That is to say, while remaining wholly other, God's presence is counter-intentional and affective. It is not revealed by means of the autonomous exertions of the self-sufficient ego. To the contrary: divine love proceeds from God and impacts human beings as the invisible glory of God that shines through the humility of cross. That is, God's presence provokes desire in the heart of the believer, who not only feels himself being gazed upon in loving compassion but also feels himself impassioned before the absolute love of God. The passio amoris is therefore wholly dependent upon God's prior advance and is consequently sustained only by God's perpetual presence. To be clear: while unilaterally established (through God's action), this reciprocal relation is essentially hetero-affective. That is to say, while one's desire to love God is an "intentional response" that is internally motivated by passion, one can only receive that passion

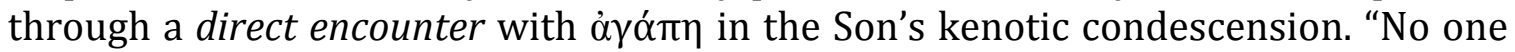
comes to the Father except through me." 194 It is a passion that arrives from outside subjectivity and is sustained only by a concrete relation with the Son. Finally, as affective, yearning is immediately felt as desire for transcendence - a desire that finds its source in another and is prior to any intellectual cogitations of the ego.

And yet, as suggested in the foregoing, the self is not purely receptive to God's love. To the contrary: divine love provokes an appropriate response. As Paul urges the Hebrews, "let us run with perseverance the race that is set before us, looking to Jesus ... who for the sake of the joy that was set before him endured the cross." ${ }^{195}$ In other words, the passio amoris is teleologically and ek-statically

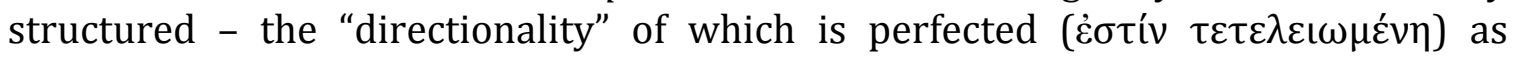
caritas. As desire, yearning is an essential movement outside of oneself. Even while $\dot{\alpha} \gamma \alpha \dot{\pi} \pi \eta$ is revealed according to the specificity of a certain passionate desire, the passio amoris is consummated as caritas (through faith). As we have said, $\dot{\alpha} \gamma \alpha \dot{\pi} \pi \eta$ is affective: it penetrates the horizon of human experience not according to the complex interplay of concept and intuition but as an immediately felt desire for transcendence. This is not to say that revelation lacks gnoseological content or is rendered meaningless. To the contrary, while communicated in a concrete encounter, the passio amoris is given a specific (ad extra) directionality. To be sure, the passio amoris is precisely that by which the believer is concretely motivated and enabled to lovingly "relate-to" the beloved. Nevertheless, yearning is meaningful precisely as "intentionally directed" towards the other (God). Caritas thus seeks to enjoin oneself to God in friendship. Not to belabor the point, let us be clear that the

194 John 14:6.

195 Hebrews 12:1-2, my emphasis. 
structure of yearning's "intentionality" is derived from God. It "is organized" by

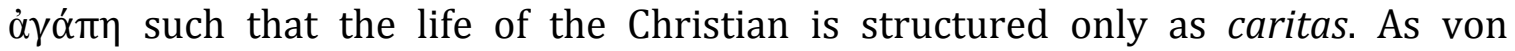
Balthasar pointed out, "the theological insight into caritas as forma virtutum immediately implies caritas as forma revelationis" - and vice versa. ${ }^{196}$ If the passio amoris is twisted back upon itself (that is, taking its bearings from itself), then the meaning of love is occluded. As we shall see then, the essential moments of caritas

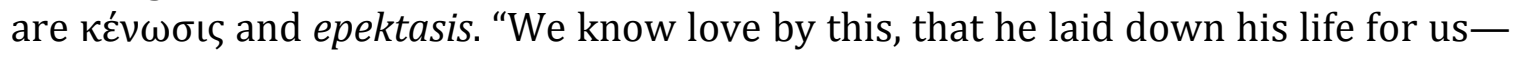
and we ought to lay down our lives for one another." 197 The form of Christian love is simultaneously derived from its source and returns to it.

Shaped by preferences and volitions, human passions are intentionally directed at their respective objects - to which the relevant passion is suitably proportioned. In particular, when "intentionally directed" at God, erotic passion becomes charity. Having explored the impressional nature of said passion, how might we subsequently characterize the "intentionality" of charity? As we have said,

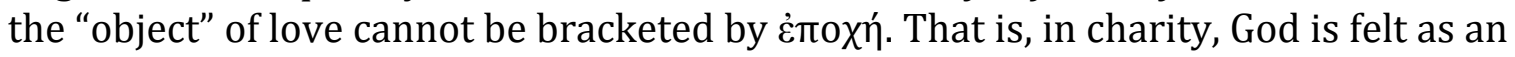
originary alterity and cannot be transcendentally reduced if the concrete relation is to be maintained. This does not imply that the "intentionality" of charity is inaccessible. For, as Paul claimed, the letter of the Spirit of the living God is "written on our hearts" (pre-cognitive affection), which is nonetheless "to be known and read by all." ${ }^{198}$ Yet Christ is the very legibility of the human heart - for which reason, the "intentionality" of charity is not manifested through a transcendentally converted gaze. As Christianity claims, the believer cannot disengage from what is "learned" through the unique spiritual consciousness of faith - from the very phenomenon of Jesus Christ. What are the implications of this axiom for the structure of love's vital passion? What is the essential modality of humanity's mysterious yearning? Let us take Paul's letter to the Philippians as our leading clue. In the manner of Christ who "emptied himself ( $\dot{\kappa \varepsilon \varepsilon} v \omega \sigma \varepsilon v \dot{\varepsilon} \alpha u \tau o ̀ v$ )" for the sake of sinful humanity, Paul exhorts the believer to "do nothing from selfish ambition or conceit."199 In order for the phenomenon of love to give itself, intentionality must not fold back upon itself (that is, derive its meaning from the self). An essential aspect of charity is therefore

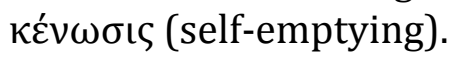

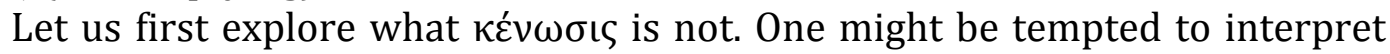
Paul's admonition against "ambition" and "conceit" from a purely ethical

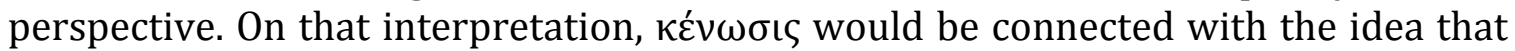
human conduct must be motivated by concern for reciprocity. The ethical agent must divest himself or herself of selfish preferences for the sake of mutual

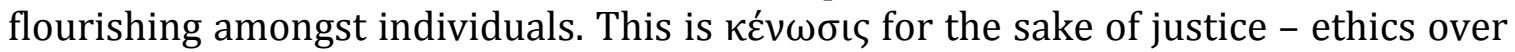
revelation. But, $\dot{\alpha} \gamma \alpha \dot{\pi} \pi \eta$ is revealed from beyond the structures of human society and is therefore not simply a regulative idea for ethical conduct. And, while reciprocity takes its bearings from the concept of an alter ego, Christian society takes its bearings from the concept of alter Christus.

196 Balthasar, Love Alone is Credible, op. cit., p. 59.

197 I John 3:16.

1982 Corinthians 3:2-3.

199 Philippians 2:3-7. 


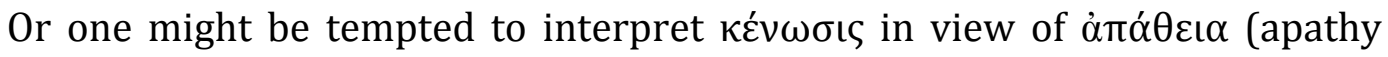
and indifference) or $\alpha \tau \alpha \rho \alpha \xi i \alpha$ (tranquility and lack of disturbance). For Stoics, Cynics and Epicureans, these states of being were constitutive of the good life. That is to say, the fundamental act of self-emptying should not only encompass one's selfish preferences but also one's passions and desires as well. In order to be free, the self must be released from its passions and desires. As we have seen, the good life had soteriological resonances for certain Greek thinkers: by way of ö $\sigma \kappa \eta \sigma \iota \varsigma$, the philosopher seeks liberation from the vicissitudes of time and the sufferings of change. While there is strand of this type of thinking in Christianity, these philosophies are too egocentric to cohere with the Pauline position.

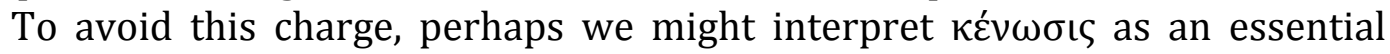
selflessness in view of the contemplative adoration of the structures of reality. As we have seen in other philosophies, the lower part of human nature (i.e. the passions) ought to be regulated for the sake of the nobler part (i.e. the rational soul). Intellectual ő $\sigma \kappa \eta \sigma \iota \varsigma$ (that is to say, dialectics) is performed for the sake of knowledge by way of disengaged and disinterested $\theta \varepsilon \omega \rho$ í $\alpha$. This was the case for Plato and Aristotle. But, as wholly other, God is not susceptible to human $\gamma v \omega \sigma \iota s$. "No one has ever seen God." Human modes of perception are utterly incapable of conforming to divine simplicity and human modes of understanding are powerless

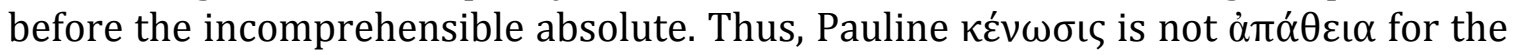
sake of contemplative $\gamma \nu \omega \sigma \iota \varsigma$; this characterizes philosophical $\dot{\varepsilon} \pi 0 \chi \eta \dot{\eta}$. This is not to say that pre-eschatological "knowledge" of God is impossible. For the Christian, the believer does in fact "see" God to some degree - albeit in a "mirror dimly." What's relevant is that "knowledge of God," while certainly inchoative, is concretely established only through the Son. "If you know me, you will know my Father also." 200 Thus, the nature of Christian knowledge is a lived relationship with the Son, who is wholly other. "Jesus said ... 'I am the way, and the truth, and the life."'201

For Paul, self-emptying is in view of loving communion with God. This is a

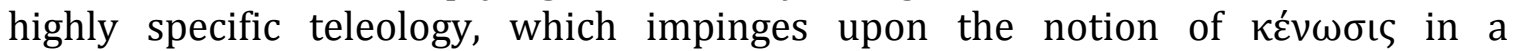

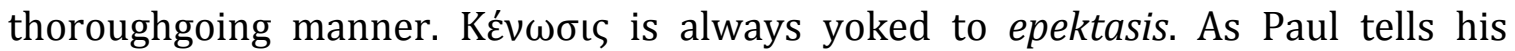

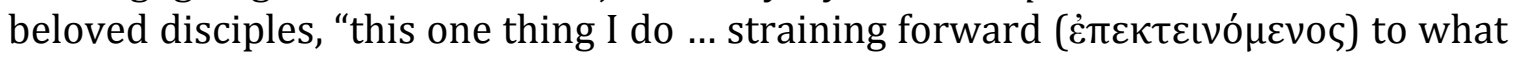
lies ahead, I press on toward the goal for the prize of the heavenly call of God in Christ Jesus." 202 There is no pre-eschatological cessation of one's movement towards God. Thus, if the very vitality of charity's striving is passionate desire (i.e. "eager

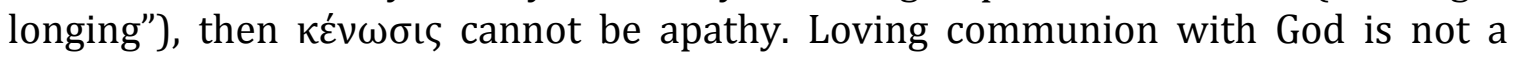
static epistemic relation but a relationship that is concretely engaged and established as perpetual movement - that is, as the race set before the adopted children of God. If God is unconditional and unlimited love, then the passio amoris must be "infinitized" in accordance with its "object." That is, God calls humanity to loving communion - to which, humanity can authentically respond only with infinite desire. Let us note well: the passions are admittedly circumscribed by being and are thus constrained in the form of a finite conatus essendi. Infinite passion always runs

200 John 14:7.

201 John 14:6.

202 Philippians 3:13-14. 
aground against the limitations of the world. Given this situation, love can only be analogically predicated of God ( $\dot{\alpha} \gamma \alpha \dot{\pi} \pi \eta)$ and humanity (caritas). Yet charity is a genuine yearning for self-transcendence, which is a movement that can only be consummated by way of unconditional commitment - to the point of death. In this, "knowledge of God" is achieved. "We know love by this, that he laid down his life for us - and we ought to lay down our lives for one another."203

We are finally in a position to characterize the "intentional passion" of charity. In the case of charity, the correlate to the axiom that God cannot be bracketed is that God must be loved "without measure" by the supremely interested believer. God is not measured in the manner of mere objects, whether by way of theoretical intentionality or the being of beings. Following Bernard's On Loving God, Aquinas states that "quod causa diligendi Deum Deus est; modus, sine modo diligere" - because the cause of loving God is God; the mode, to love without mode. ${ }^{204}$ Charity does not seek self-contentment through an essential purgation of one's passions (кó $\theta \alpha \rho \sigma \iota \varsigma) ;$ nor does it bracket one's lived relationship with God for the sake of a theoretical

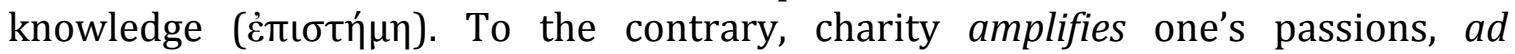
infinitum, in the direction of God (the infinite source of life). This infinitization of passion is concretely expressed and experienced in the impossible excesses of charity whereby God's presence is experienced in its entire gratuity. "Since God loved us so much, we also ought to love one another... if we love one another, God lives in us."

And yet this passion wills its downfall (in death), where God's love "is perfected" and shines forth in a complete theophany, where the peril of infinitized experience finds the bliss of eternal life, where the glory of each unique Self shines forth in all of its transcendent haecceitas.

\section{§19: Conclusion: Love as a way of life}

In conclusion, let us summarize some of this essay's findings:

(1) Love is neither irrational nor merely affective but furnishes knowledge of the other, an utterly unique but genuine experience of alterity that exceeds ordinary knowledge. It is a knowledge that is obtained by a conversion of the gaze upon the gratuitous presence of the other, and it is knowledge obtained by way of the leap of faith (into the superabundant alterity of the other). Love does not derogate from the dignified rationality of reason but opens access to that which transcends reason. We have thus outlined a tradition, spanning from Augustine (non intratur in veritatem nisi per caritatem) to Bernard of Clairvaux (amor ipse notitia est), from Pascal (love as the third realm of knowledge) to Marion (love as the transvaluation of the will), which represents a minority report in the history of thought since it characterizes love as an ordo cognoscendi that surpasses theoretic knowledge.

(2) Moreover, love gives the very reality of the self and the other. "Love of the other repeats creation through the same withdrawal wherein God opens, to what is not, the right to be, and even the right to refuse Him." 205 The other can accede to its

203 I John 3:16.

${ }^{204}$ Aquinas, Summa Theologica, IIaIlae, q. 27, a. 6.

205 Marion, Prolegomena to Charity, op. cit., p. 167. 
very own reality only if I allow it; that is, by renouncing my intentionality in order to create the space for the other to be. Concomitantly, the other's counter-gaze is the condition of possibility for the existence of my own gaze. The other allows me to

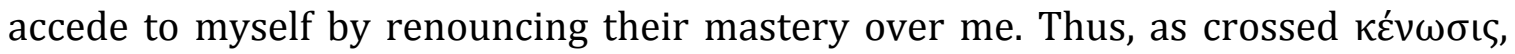
love is not merely the transgression of intentionality but enables the mad ecstasy of haecceitas. In this manner, the self and the other genuinely appear in the $\kappa \alpha \theta^{\prime} \alpha \dot{\tau} \tau o$ experience of love.

(3) Love is the preeminent and paradigmatic experience for human beings because love reflects the very intelligibility of the world. For Plato, as we saw, reality is susceptible of being known in virtue of the erotic structure of the human soul. By passionately questioning worldly modes of being and thought, the soul is able to attain transcendence. Yet, unlike the Greeks, the phenomenology of love has uncovered love as concrete, social transcendence as opposed to abstract, cosmic transcendence. This is the fundamental difference. The social relation of love is the foundation of the world because this relation is established only by giving my being and my world unto the other - which, in turn, enables each term in the social relation to accede their very own reality, qua haecceitas. In this manner, love has been discovered as the preeminent human experience since it gives concrete meaning to human existence.

(4) Love is a way of life; it is not a static, even if exceptional, posture towards reality. The conversion of the gaze and the ecstasy of haecceitas is an ever-continuing process of existential engagement vis-à-vis the other; love therefore is supreme interestedness. Yet it is not modeled after being's interest. To the contrary, love's interest transcends worldly modes of being thereby completing the self's inner dynamism, which aims at the other. Lacking perfect knowledge (of the Forms or the other), one can only desire to move ever closer towards it. Erotic transcendence, in the midst of worldly finitude, necessarily implies an ongoing dynamism. Thus, as a way of life, love treats neither reason nor worldly modes of being as ultimate; it perpetually transcends worldly modes of knowledge, by slackening the intentional rapport with the world, in order to "see" the invisible gift that precedes and gives meaning to the world. And, it does so by personally embraced, passionate ecstasy (towards the other).

(5) The underlying concrete unity of the aforementioned has been uncovered by way of phenomenological explication. In particular, we have privileged the theory of

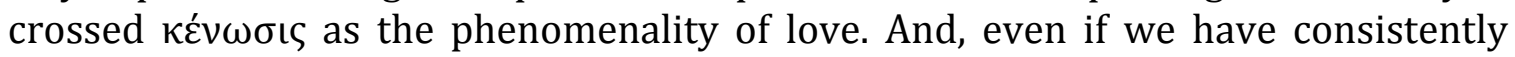
criticized Heidegger's existential analytic, we have privileged the active and dynamic existential engagement with reality by way of the affections. Finally, we have privileged the appearance of the superabundant gift by way of the experience of the impossible; that is, by way of the excessive love that is madly poured forth in a sinful and rational world. 


\section{Bibliography}

Aristotle. The Nicomachean Ethics. Trans. David Ross. Oxford University Press, 1998.

Aquinas, Thomas. Summa Theologica. Trans. Fathers of the English Domincan Province. New York: Benzinger Brothers, 1948.

. Summa Boetium de Trinitate. Trans. Rose E. Brennan, S.H.N. Verlag Herder Publishing Company, 1946.

Augustine. Concerning the City of God against the Pagans. Trans. Henry Bettenson. London, England: Penguin Books, 2003.

. De Trinitate. Trans. Edmund Hill. Hyde Park, New York: New City Press, 1991.

. The Confessions. Trans. Maria Boulding. New York: Vintage Books, 1998.

Balthasar, Hans Urs von. Love Alone is Credible. Trans. D. C. Schindler. San Francisco, California: Ignatius Press, 2004.

Burrell, David. Knowing the Unknowable God: Ibn-Sina, Maimonides, Aquinas. Notre Dame, Indiana: University of Notre Dame Press, 1986.

Caputo, John. "The Experience of God and the Axiology of the Impossible," in The Experience of God: A Postmodern Response. Eds. Kevin Hart and Barbara Wall. Fordham University Press, 2005.

Descartes, René. The Passions of the Soul. Trans. Elizabeth S. Haldane and G. R. T. Ross. Cambridge University Press, 1967.

Hadot, Pierre. What is Ancient Philosophy?. Trans. Michael Chase. Cambridge, Massachusetts: Harvard University Press, 2002.

Heidegger, Martin. Being and Time. Trans. Joan Stambaugh. Albany, New York: State University of New York Press, 1996.

. History of the Concept of Time: Prolegomena. Trans. Theodore Kisiel. Bloomington, Indiana: Indiana University Press, 1985.

. Introduction to Metaphysics. Trans. Gregory Fried and Richard Polt. Yale University Press, 2000.

Henry, Michel. I am the Truth: Toward a Philosophy of Christianity. Trans. Susan Emanuel. Stanford, California: Stanford University Press, 2003. 
. Material Phenomenology. Trans. Scott Davidson. Fordham University Press, 2008.

Husserl, Edmund. Ideas Pertaining to a Pure Phenomenology and to a Phenomenological Philosophy, First Book: General Introduction to a Pure Phenomenology. Trans. F. Kersten. The Hague: Martinus Nijhoff Publishers, 1983.

. Cartesian Meditations: an Introduction to Phenomenology. Trans. Dorion Cairns. Kluwer Academic Publishers, 1999.

. The Idea of Phenomenology. Trans. William P. Alston and George Nakhnikian. The Hague: Martinus Nijhoff Publishers, 1964.

Kant, Immanuel. Grounding for the Metaphysics of Morals. Trans. James W. Ellington. Indianapolis, Indiana: Hackett Publishing Company, 1993.

. Religion within the Boundaries of Mere Reason. Trans. and eds. Allen Wood and George di Giovanni. Cambridge University Press, 2006.

Kierkegaard, Soren. Kierkegaard's Writings. VII, Philosophical Fragments, or A Fragment of Philosophy and Johannes Climacus, or De Omnibus dubitandum est. Trans. and ed. Howard and Edna Hong. Princeton: Princeton University Press, 1985.

Kisiel, Theodore. The Genesis of Heidegger's Being and Time. Berkley and Los Angeles, California: University of California Press, 1995.

Levinas, Emmanuel. Totality and Infinity: an Essay on Exteriority. Trans. Alphonso Lingis. Pittsburgh, Pennsylvania: Duquesne University Press, 1969.

. Discovering Existence with Husserl. Trans. Richard A. Cohen and Michael B. Smith. Evanston, Illinois: Northwestern University Press, 1998.

. Otherwise than Being, or Beyond Essence. Trans. Alphonso Lingis. Pittsburgh, Pennsylvania: Duquesne University Press, 2009.

. "Martin Heidegger and Ontology." Trans. Committee of Public Safety. Diacritics 26.1 (1996).

. On Escape. Trans. Bettina Bergo. Stanford, California: Stanford University Press, 2003.

. Proper Names. Trans. Michael B. Smith. Stanford, California: Stanford University Press, 1996. 
Marion, Jean-Luc. Prolegomena to Charity. Trans. Stephen E. Lewis. New York: Fordham University Press, 2002. . The Erotic Phenomenon. Trans. Stephen E. Lewis. Chicago: The University of Chicago Press, 2007.

Nietzsche, Friedrich. The Birth of Tragedy, out of the Spirit of Music. Trans. Shaun Whiteside. London, England: Penguin Books, 2003.

Plato. The Symposium. Trans. Christopher Gill. London, England: Penguin Books, 1999. 